Portland State University

PDXScholar

\title{
A Study of Japan's Foreign Policy Behavior: The Discrepancy between Japan's Foreign Policy and Its Voting Behavior in the United Nations General Assembly
}

Atsuko Sato

Portland State University

Follow this and additional works at: https://pdxscholar.library.pdx.edu/open_access_etds

Part of the Political Science Commons

Let us know how access to this document benefits you.

\section{Recommended Citation}

Sato, Atsuko, "A Study of Japan's Foreign Policy Behavior: The Discrepancy between Japan's Foreign Policy and Its Voting Behavior in the United Nations General Assembly" (1994). Dissertations and Theses. Paper 4787.

https://doi.org/10.15760/etd.6671

This Thesis is brought to you for free and open access. It has been accepted for inclusion in Dissertations and Theses by an authorized administrator of PDXScholar. Please contact us if we can make this document more accessible: pdxscholar@pdx.edu. 
THESIS APPROVAL

The abstract and thesis of Atsuko sato for the Master of Arts in Political Science were presented August 11, 1994, and accepted by the thesis committee and the department.

COMMITTEE APPROVALS:

DEPARTMENT APPROVAL:
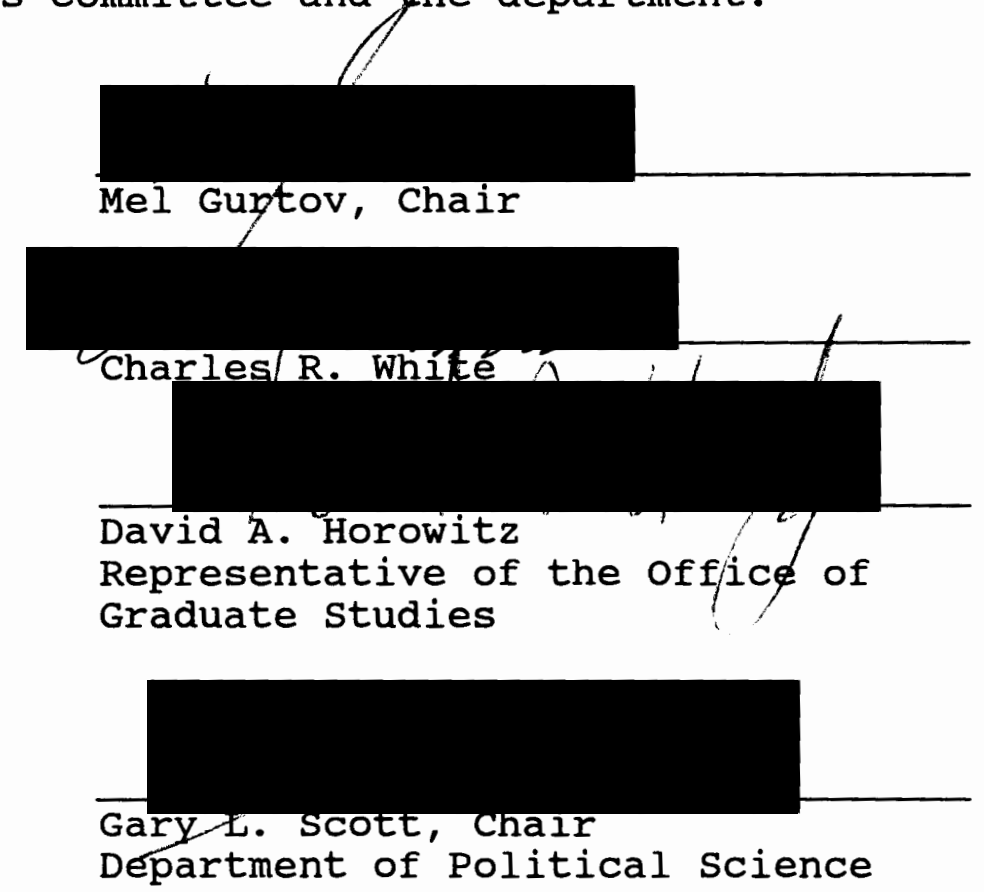

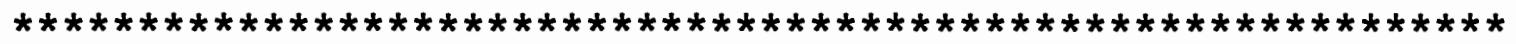

ACCEPTED FOR PORTLAND STATE UNIVERSITY BY THE LIBRARY

by on 12 Alecenbex 1994 


\section{ABSTRACT}

An Abstract of the thesis of Atsuko sato for the Master of Arts in Political Science presented August 11, 1994.

Title: A Study of Japan's Foreign Policy Behavior: The Discrepancy between Japan's Foreign Policy and Its Voting Behavior in the United Nations General Assembly.

Japan has maintained a low profile in its diplomacy since the end of World War II, relying heavily on the United states for its security and prosperity. The cold war structure allowed Japan to maintain its passive foreign policy behavior. By the end of 1980s, West-East confrontations largely ended and global issues such as arms control, environmental problem, human rights, economic development, and ethnic conflicts became the main international concerns. It was expected that in this changed world environment, Japan as an economic power, would take on a more active international role. Yet Japan has not shown any significant political initiative despite of its willingness to contribute to international peace and prosperity. The primary purpose of this thesis is to identify the underlying factors that have kept Japan from being a strong voice and taking initiatives in world affairs. 
This study presents Japan's official guidelines on global issues as its foreign policy. The guidelines indicate that Japanese foreign policy is too general and broad; it aims at cooperation with everybody. Japan's foreign-policy behavior is represented by its voting behavior in the United Nations General Assembly. Inasmuch as it has adopted a U.N.-centered diplomacy, I believe that Japan's voting in the U.N. delineates its foreign-policy behavior. A statistical method of factor analysis I apply in this study delineates Japan's stance and voting cohesion issue by issue. The voting maps reveal Japan's ambivalent stance on most of the issues. Japan's voting pattern often does not follow its idealistic guidelines.

The study further inquires into the discrepancy between Japan's foreign policy and its foreign-policy behavior. The main reasons seem to stem from its dependent security relations with the United States, the close economic ties with Asian countries and the oil-producing Middle East states, and historical constraints in relations with Asia. In addition, Japan's ambiguous foreign policy guidelines are themselves a factor which creates the discrepancy. These factors prevent Japan from independently reacting to international incidents. Yet given its financial and technological advances, Japan could play a leading role within the framework of international organizations, especially on global environmental issues. 


\title{
A STUDY OF JAPAN'S FOREIGN POLICY BEHAVIOR: THE DISCREPANCY BETWEEN JAPAN'S FOREIGN POLICY AND ITS VOTING BEHAVIOR IN THE UNITED NATIONS GENERAL ASSEMBLY
}

\author{
by
}

$$
\text { ATSUKO SATO }
$$

A thesis submitted in partial fulfillment of the requirements for the degree of

\author{
MASTER OF ARTS \\ in \\ POLITICAL SCIENCE
}

Portland State University

1994 


\section{ACKNOWLEDGMENTS}

I gratefully acknowledge academic support from teachers at the Portland State University. My thanks should go first to my principal advisor, Professor Mel Gurtov, who gave me consistent guidance and support. I appreciate Dr. Charles R. White, who has supported the study of the methodology throughout the years and gave me considerable advice. I also thank Dr. David A. Horowitz and Dr. Gill Latz, who made thoughtful comments, and Mr. Wes Brenner, who answered technical questions concerning a data processing.

I would like to take this opportunity to thank all faculties in the Political Science Department, who gave me intellectual background, and the secretary, Ms. Betty Cox, who patiently helped me with the graduate paper work. I also appreciate Mr. Christopher Johnson, who game me encouraging comments.

Last but not least, a special expression of gratitude goes to my father, mother, and sister for their warmhearted support and understanding. 
TABLE OF CONTENTS

PAGE

ACKNOWLEDGMENTS $\ldots \ldots \ldots \ldots \ldots \ldots \ldots \ldots \ldots$ ii

IIST OF TABLES $\ldots \ldots \ldots \ldots \ldots \ldots \ldots \ldots \ldots \ldots \ldots \ldots$ vii

IIST OF FIGURES $\ldots \ldots \ldots \ldots \ldots \ldots \ldots \ldots \ldots \ldots \ldots$ viii

CHAPTER

I INTRODUCTION $\ldots \ldots \ldots \ldots \ldots \ldots \ldots \ldots \ldots \ldots \ldots$

A Study of Foreign Policy

and Foreign-Policy Behavior .......6 6

Japan's U.N.-Centered Diplomacy

and Its Identity in the U.N. ....... 11

Japan and the U.N. in the Changing

International Environment ........ 18

II JAPAN'S FOREIGN POLICY BETWEEN 1988 AND 1992

Actors in Japan's Foreign-Policy Making .. 25

Overview of Japan's Foreign Policy ...... 27

East-West Relations

and Disarmament Issues ......... 38

The Middle East Peace Problem .........44

Human Rights Issues $\ldots \ldots \ldots \ldots \ldots \ldots \ldots 47$

Economic Development

in Developing Countries ......... 50

Global Environmental Issues ......... 55

Conclusion $\ldots \ldots \ldots \ldots \ldots \ldots \ldots \ldots \ldots$ 
III JAPAN'S VOTING BEHAVIOR FROM 1988 TO 1992

The General Assembly

Between 1988 and $1992 \ldots \ldots \ldots \ldots \ldots$......6.

Factor Analysis of Voting Records ...... 65

Methods of Factor Analysis

Issues at the Forty-Third General Assembly

Voting Dimensions in 1988

Issues at the Forty-sixth

General Assembly

Voting Dimensions in 1991

Conclusion

IV A COMPARISON OF FOREIGN POLICY

TO FOREIGN-POIICY BEHAVIOR

Japan's Basic stance ................. 92

Arms Control and Disarmament Issues ..... 98

The Middle East Peace Problem .......... 104

Human Rights Issues ................. 113

Economic Development

in Developing Countries .......... 121

Global Environmental Issues ........... 126

V CONCLUSION: THEORY

OF JAPAN'S FOREIGN-POLICY BEHAVIOR

Power and Influence ................ 133
Influence Based on Military Power
Influence Based on Economic Resources
Influence Based on
Psychological Constraints

A Lack of Coherent Foreign Policy ....... 138

A Final word ..................... 140 
APPENDICES

A FACTOR SCORES BY COUNTRY

OF THE 43RD GENERAL ASSEMBLY ......... 148

B FACTOR SCORES BY COUNTRY

OF THE 46TH GENERAL ASSEMBLY .......... 152 


\section{LIST OF TABLES}

TABLE

PAGE

I Japanese Financial and Professional

Contributions to the U.N. .............. 20

II The Number of Adopted Resolutions

Between 1988 and $1992 \ldots \ldots \ldots \ldots \ldots \ldots$

III Eigen Value and Percentage of Variance, Voting Dimensions in the 43 rd session

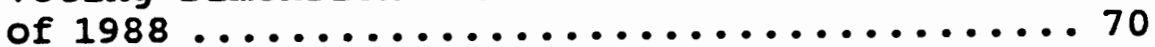

IV Rotated Factor Matrix,

the $43 \mathrm{rd}$ General Assembly ............. 71

V Eigen Value and Percentage of Variance, Voting Dimensions in the 46 th Session

of $1992 \ldots \ldots \ldots \ldots \ldots \ldots \ldots . \ldots \ldots \ldots . \ldots \ldots \ldots$

VI Rotated Factor Matrix,

the 46 th General Assembly ............. 82 


\section{LIST OF FIGURES}

FIGURE

PAGE

1. A Model of Foreign-Policy Behavior ............. 3

2. Factor Scores on "Social and Human Rights Issues" (Vertical) and "Israeli-Palestinian conflicts" (Horizon) at the 43 rd General Assembly ........................ 76

3. Factor Scores on "Social and Human Rights Issues" (Vertical) and "Arms Reduction" (Horizon) at the 43 rd General Assembly ..... 77

4. Factor Scores on "Arms Reduction" (Vertical) and "Issues of Developing Countries" (Horizon) at the 43 rd General Assembly ............ 78

5. Factor Scores on "Humanitarian and other Global Issues" (Vertical) and "Israeli-Occupied Territories" (Horizon) at the 46th General Assembly ......................... 86

6. Factor scores on "Israeli-occupied Territories" (Vertical) and "Palestinian Refugees' Issues" (Horizon) at the 46 th General Assembly .....8 87

7. Factor Scores on "Humanitarian and Other Global Issues." (Vertical) and "Arms Control and Disarmament" (Horizon) at the 46 th General Assembly .........................88 
CHAPTER I

\section{INTRODUCTION}

After its defeat in World War II, Japan was obliged to follow the dictates of the supreme command of the Allied Powers. Even after the end of the U.S. occupation, Japan's political, security, and economic dependence on the United States continued and Japan generally failed to take any initiative for its foreign policy. The cold war structure of international politics was responsible for Japan's reliance on the United States. Under the U.S. umbrella, Japan practiced a passive or reactive diplomacy side by side with promotion of its interests. As a result, Japan today has gained significant power in the international economy, but its diplomatic profile has not shown visible change. Yet, international issues such as environmental protection, human rights, arms control and peace keeping confront Japan with the critical imperative of rethinking its foreign policy.

Japan resumed its sovereignty when it signed the Peace Treaty with the United States in 1951, and its diplomacy became active after Japan was admitted into the United Nations as well as other international organizations in 1956. Japan believed that the United Nations was the source of international legitimacy and expressed the will of the global 
community. ${ }^{1}$ Japan therefore adapted a U.N.-centered diplomacy. Inasmuch as this concept remains a primary fixture of Japanese policy making, and also in public dialogue on foreign policy, I believe Japan's voting record at the U.N. is a crucial element of its foreign-policy behavior.

This study is composed of three parts and encompasses a series of objectives: 1) to assess Japan's foreign policy toward selected issues: international security; economic development in developing countries; human rights; the Middle East; and the global environment; 2) to inquire into Japan's foreign-policy behavior toward these issues on the basis of its voting record in the United Nations General Assembly; 3 ) finally, to analyze and compare the discrepancy between Japan's stated foreign policy and foreign-policy behavior and to find determinants of that behavior behind its policy. Although a nation's official foreign policy may be thought of as principles or guides to that nation's behavior, it often does not conform with actual behavior. Foreign-policy behavior is influenced by a host of factors. (Figure 1) other elements, including domestic politics, interstate relationships, and global conditions and environments, are also critical determinants of foreign-policy behavior.

In the introductory chapter, I specify the framework of this study, and define foreign policy and foreign-policy

1 sadako Ogata. "The United Nations and Japanese Diplomacy," Japan Review of International Affairs, Vol.IX, No.2, Fall/winter 1990: 144 . 


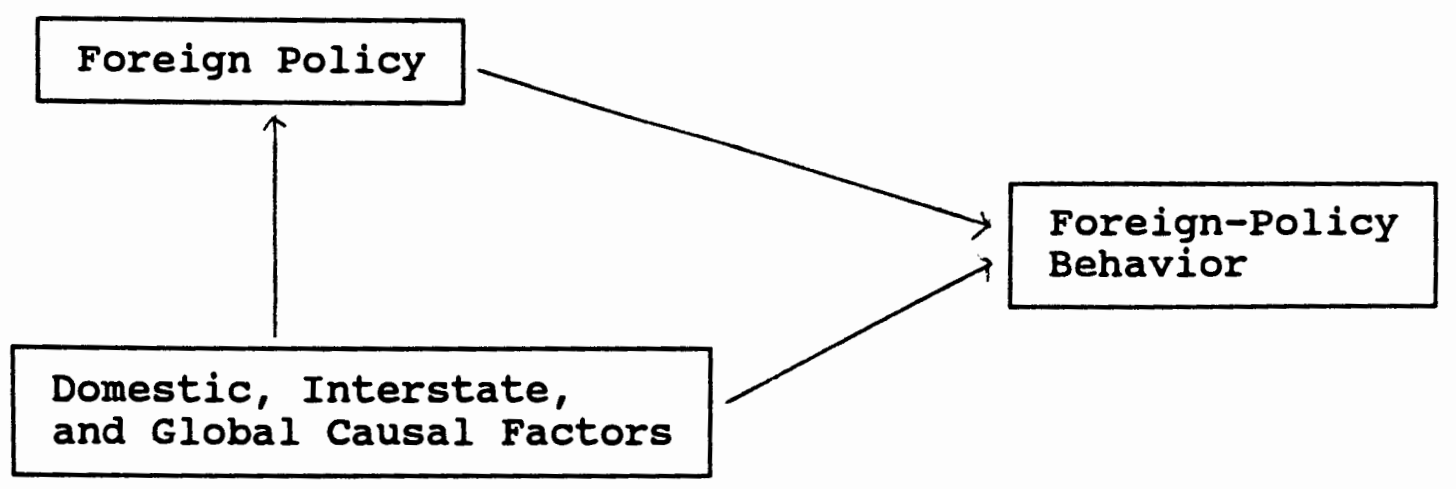

Figure 1. A model of foreign-policy behavior.

behavior. I explain the significance of the empirical study of Japan's voting behavior in the United Nations for studies of Japan's foreign-policy behavior, and review Japan's policy behavior in the United Nations with a historical perspective.

In Chapter II, the foreign policy that the Government of Japan announced between 1988 and 1992 is reviewed as a set of official guidelines. Here I focus only on official statements from the Ministry of Foreign Affairs because of my narrow definition of foreign policy. A finding of this chapter is that the Government of Japan has general and broad policies that are not specific enough to react to pressing international issues and crises.

Chapter III seeks, through examination of a series of resolutions in the United Nations between 1988 and 1992, to identify patterns of Japan's voting behavior. Applying quantitative analysis, I determine Japan's position on international security issues, the Middle East peace problem, issue of economic development in developing countries, and 
social and humanitarian matters. Attention is given to group cohesion (which bloc Japan belongs to), and Japan's stance (such as negative, neutral, positive) on each issue.

In chapter IV, patterns of Japan's voting behavior at the United Nations that were uncovered in chapter III and Japan's foreign policy statements are compared and analyzed. The analysis in this chapter finds a gap between Japan's official foreign policy and its foreign policy behavior. Japan's foreign-policy behavior is not necessarily a reflection of its foreign policy. Where Japan has not implemented its foreign policy through its voting behavior in the United Nations, I examine the range of possible factors that may account for the discrepancy. With recognition that foreign policy behavior occurs at the state and inter-and/or multistate level of analysis, the examination focuses on the impact of certain internal and external stimuli as influential factors.

since Japan has a broad, vague attitude of "being with everybody" and has a longstanding policy of cooperation with Western democratic nations, the foreign policy behavior of other states must be taken into consideration. Thus, international agreements, such as U.N. resolutions, and international discussions, such as the Group of seven meetings, may constitute other interstate or global influences on Japan's foreign policy behavior. Japan's geographical and historical experiences are also critical 
factors that constrain its foreign-policy behavior. The capabilities of a state, such as its military power and economic resources influence its foreign-policy behavior as well.

In chapter $V$, I conclude this study with a theoretical consideration of Japan's foreign-policy behavior. A key finding is that beyond Japan's lack of military power and natural resources, or consideration of its historical relations with other countries, it is the lack of a sufficiently precise foreign policy itself which affects Japan's international behavior.

I would like to make clear two points concerning methodology in this study. First, while I consider that the nation-state has been and remains the primary actor in the world system, inter-governmental or non-governmental organizations and multinational corporations have emerged as important actors. Thus I concentrate on relations between nation-states and other international actors as a level of analysis.

Second, the primary emphasis of this study is on empirical analysis. It examines and analyzes Japan's foreign policy and its foreign policy behavior on several important issues. Although the debate on qualitative and quantitative approaches to foreign policy study has not been resolved, I have tried to combine advantages of both approaches in my research. In chapter II, I focus on studies of primary 
materials and documents to review Japan's official policy pronouncements. In chapter III, I employ factor analysis to assess Japan's voting behavior in General Assembly. This quantitative method is particularly useful for extracting patterns of behavior from large number of events. In chapter IV, in the quest to find determining factors of Japan's foreign-policy behavior other than its official policy, I return to the material of previous chapters and employ a number of secondary sources.

A STUDY OF FOREIGN POLICY AND FOREIGN-POLICY BEHAVIOR

The definition of foreign-policy behavior often differs substantially from a state's declared foreign policy. Foreign policy is defined by usually vague expressions of principles, national interests, aims, and conditions in the environment, not by the actions of the government. Foreign policy may mean different things to different researchers. Because of the diversity of its definition, the study of foreign policy may be concerned with the policies that states declare, the decisions made within governmental circles, the processes by the which governments arrive at policies and decisions, or the actions actually taken by their official representatives. Based on what part of phenomena are of interest to the researcher, there are three different definitions in the existing literature.

First, Rosenau, who has contributed to general theory in 
foreign policy studies over the past decade, has called for applying a comparative approach to the study of foreign policy processes and behavior. By foreign policy he means "the authoritative actions which governments take or are committed to take in order to preserve the desirable aspects of the international environment or to alert its undesirable aspects." ${ }^{2}$ His approach to foreign policy is, in a broad sense, closely linked to foreign-policy behavior and he stresses that foreign policy is only one form of adaptive behavior in which national societies engages. The study of foreign policy as adaptive behavior seeks an understanding of common factors through a theoretical formulation.

Second, Russett and Starr, concerned with the ideas of sovereignty and territoriality, define foreign policy as "a set of guides to choices being made about people, places, and things beyond the boundaries of the state." ${ }^{3}$ similarly, Charles 0 . Lerche, Jr. and Abdul A. Said define it as "the general principles by which a state governs its reaction to the international environment. ${ }^{4}$

Third, scientific analyses of interstate behavior are

2 James N. Rosenau. Comparing Foreion Policies (New York: Halsted Press, Division of John Wiley \& Sons, Inc., 1974) 6 .

3 Bruce Russett and Harvey Starr, World Politics (New York: W.H. Freeman and Company, 1989) 186-188.

4 Charles O. Lerche, Jr. and Abdul A. Said, Concept of International Politics, (New Jersey: Prentice-Hall, Inc., 1970) 30 . 
concerned not with what a government aspires to accomplish but with what it actually does. According to these analyses, foreign policy may be viewed as "those official actions (and reactions) which sovereign states initiate (or receive and subsequently react to) for the purpose of altering or creating a condition (or problem) outside their territorialsovereign boundaries. $" 5$ Precisely speaking, however, this is a definition of foreign policy behavior but not of foreign policy. Rosenau's definition is much broader and consists of both foreign policy and its implementation. In this study, I would like to separate foreign-policy behavior from foreign policy. Thus I define foreign policy as a set of guidelines by which a state governs its reaction to the international environment on behalf of a nation.

The ambiguity of the concept of foreign policy makes it difficult to operationalize for successful quantitative research on foreign policy. A state's foreign policy can be seen in the formal statements which include three elements: 1) formulation of the objective in the most precise terms possible; 2) the nature of the action to be undertaken, stated with sufficient clarity to guide and direct the state's officials; and 3 ) the forms and perhaps the amounts of national power to be applied in pursuit of the objective. ${ }^{6}$

5 Jonathan Wilkenfeld, et al. Foreign Policy Behavior: The Interstate Behavior Analysis Model. (Beverly Hills: Sage Publications, 1980) 22 .

6 Ibid., 31. 
Thus foreign policy can be often found in the policies of a government or in the statements by a government's officials.

After a policy is determined, based on the objective that a state seeks, and the capability for action within the particular situation, the policy will become identified as foreign policy behavior. The most important issue that implementation raises for the study of foreign policy behavior is that it shifts the focus from the process of decision making to the actor itself. Foreign policy behavior is not merely activities guided by a state's foreign policy but also behavior influenced by that policy and other environmental factors. As I showed in the model of foreign policy behavior (Figure 1), foreign policy is clearly an important determinant of behavior, but there is a gap between foreign policy decisions (outputs) and foreign policy behaviors (outcomes).

Foreign-policy behavior refers to the observable acts of individuals serving in an official government capacity. Because of the observability of foreign-policy behavior, as a dependent variable, a good deal of scientific research has been done. Analysts of foreign-policy behavior typically examine actual foreign policy events. Event data sets such as the World Events Interaction Survey (WEIS), the Comparative Research on the Events of Nations (CREON), and the conflict and Peace Data Bank (COPDAB) have been used for scientific research on foreign-policy behavior. However, event data set 
analysis has been criticized for its unreliability and difficulty of validation. For example, there are possible nationalistic biases in the compilation of sources, in the choice of sources, and an overreporting of various event sequences. ${ }^{7}$

As an alternative, some analysts use roll-call votes in the United Nations General Assembly (UNGA) as an indicator of international behavior. There are a number of reasons why voting records of the General Assembly are a useful indicator of foreign-policy behavior. First, the U.N. has a nearly universal membership and its frequent meetings and addresses provide a forum for a broad range of subjects on the international agenda. Second, all member states are required to represent national positions on every issue. And the General Assembly has also proved hospitable to member concerns by imposing no real barriers to putting questions on the agenda. ${ }^{8}$ The General Assembly can thus be seen as a kind of global parliament in which all member states express their opinions on the international agenda.

Thirdly, the General Assembly is the only one of the six principal U.N. organs in which all member states are equally

7 See, for example, Llewellyn D. Howell, "A Comparative study of the WEIS and COPDAB data sets," International Studies Quarterly, 27, 1983, pp.149-168. Charles A. MacClelland, "Let the User Beware," International Studies Quarterly, 27, 1983, pp.169-177.

${ }^{8}$ M. J. Peterson, The General Assembly in World Politics (Boston: Allen \& Uniwin Inc., 1986) 2. 
represented and which employs a majority rule for adoption of resolutions. Resolutions directed toward state conduct outside the organization are not binding of themselves, but the rules thus enunciated may have legal force if they are regarded as statements of customary international law or authoritative interpretations of the U.N. Charter. ${ }^{9}$ Because voting behavior of the member states touches upon the final stage of activity centered on the adoption of resolutions, they take voting seriously. Finally, the voting data in the General Assembly are accessible and reliable. Therefore voting behavior in the U.N. General Assembly represent the official actions of authoritative decision makers or representatives of nations.

To what extent does voting behavior in the U.N. General Assembly also describe the foreign-policy behavior of a nation? The answer might be different for each country. In the case of Japan, however, voting behavior in the General Assembly seems especially salient to foreign policy behavior. To support this assertion, we must consider historical relationship between Japan and the United Nations.

JAPAN'S U.N.-CENTERED DIPLOMACY AND ITS IDENTITY IN THE U.N.

After its defeat in World War II, Japan's reentry into the international community was put off for more than ten

9 Robert E. Riggs and Jack C. Plano, The United Nations (Belmont: Wadsworth Publishing Company, 1994) 22-29. 
years. In 1951, the signing of Peace Treaty and the JapaneseAmerican Security Treaty were greeted with high expectations. In 1951, Prime Minister Yoshida said in the Diet:

Chapter III [of the Peace Treaty]...stipulates Japan's acceptance of ...Article 2 of the United Nations Charter and the confirmation by the Allied Powers that they will also be guided by the same principles in their relations with Japan. Such a stipulation would be necessary if Japan were to be permitted to join the United Nations forthwith upon her recovery of independence. ${ }^{10}$

This enthusiasm for admission to the U.N. was held not only by the Japanese government but also by public opinion, as reflected in polls taken by the leading newspapers and magazines in Japan. ${ }^{11}$

Japan had several objectives in joining the United Nations. One of the most important motives was the security guarantee. Under its postwar Constitution, Japan abolished armaments and renounced the right of belligerency. Although Japan established a defense force, it was impossible to build up military strength sufficiently strong to defend its security, since there were various legal obstacles under the Peace Constitution, and economic difficulties after the World War II. ${ }^{12}$ A second objective was to contribute to world peace

10 Proceedings in the House of Councilors, 12th Sess., No.3, 12 oct. 1951, p.3, cited by the Japanese Association of International Law, Japan and the United Nations (New York: Manhattan Publishing Company, 1958) 79-80.

11 The Japanese Association of International Law, 4-5.

12 Ibid., 228. 
and security as a member of the international community. Japan, as the only country which had experienced the horrors of the atomic bomb, desired to take up the issues of arms control under the auspices of the United Nations. Third, Japan expected to solve its social and cultural problems that existed in Japan. At that time, it was not regarded as equal to the standards of civilized nations because of the problems of minorities, labor conditions, and the status of women. International economic cooperation, particularly with Asian countries was also one of objectives for joining the U.N. For Japan, with its industrial capacity, promotion of economic exchange with the raw material zones of Asia was essential. Having abandoned its past expansionist policy, it was most desirable that Japan's contribution to the economic development of Asia be coordinated with the projects of the United Nations. ${ }^{13}$

Following the Peace Treaty which became effective in 1952, Japan requested admission to the United Nations. However, in spite of support by a majority of members, because of the one negative vote of the USSR which was not a signatory of the Peace Treaty, Japan's admission to the United Nations was blocked. After intensive multilateral and conferences and bilateral meetings with the Soviet, Japan signed peace agreement with USSR in 1956. At the same year, finally Japan was admitted into the U.N. under the
13
Ibid., 232-233. 
sponsorship of the United States. For Japan this event had great symbolic significance for regaining international status as well as for strengthening national security.

Right after Japan's admission to the United Nations, there was a high degree of enthusiasm and support for the U.N. in Japanese official statements. When it was admitted to the body, Foreign Minister Mamoru Shigematsu expressed Japan's aspiration of its role in the United Nations. Japan desired to play a moderating influence between the developing countries of Asia and Africa, and the developed countries, given its mixed identity, as a developed, yet Asian nation and aligned with the West. In February 1957, Prime Minister Nobusuke Kishi initiated three foreign policies: (1) the use of the United Nations as the main instrument of Japanese diplomacy; (2) cooperation with other free democratic nations; and (3) the promotion of Japan's national interests as part of the Afro-Asian bloc (AA bloc). 14 Thus Japan's U.N.-centered Diplomacy was officially pronounced. It was generally interpreted that Japan should conduct its diplomacy in line with the objectives and principles of the United Nations. ${ }^{15}$

Although Japan was supposed to take a stance as a member

14 Speech by Prime Minister Noboru Kishi at the 26th Session of the National Diet on February 4, 1957.

15 Yasuhiro Ueki, "Japan's UN Diplomacy: Sources of Passivism and Activism," Japan's Foreign Policy After the Cold War, ed. Gerald L. Curtis (New York: An East Gate Book, 1993) 348-349. 
of the AA bloc, this has not been reflect in its voting behavior in the United Nations. Saburo Matsumoto, a Japanese political scientist, researched Japan's voting behavior in the U.N. between 1956 and 1963. His study shows that the incidence of Japan's concurrence with the $A A$ bloc was the highest on human rights issues between the Eleventh and Fourteenth General Assemblies (1956-1959)..$^{16}$ However, the overall propensity of Japan to vote with the majority of the $A$ bloc was less than 50 except in the Eleventh session (798). ${ }^{17}$ Japan began to express disagreement, not only with the positive neutralist countries, but also with the proWestern countries within the AA bloc. After 1960, it was increasingly isolated from other AA bloc nations.

Using factor analysis, Hayward R. Alker and Bruce M. Russett studied voting behavior in the U.N. General Assembly theoretically and empirically. Their factor analysis found that at the Twelfth General Assembly in 1957 Japan voted with the AA bloc for East-West and North-South issues, but isolated itself from the bloc on self-determination issues (questions concerning non-self governing territories). ${ }^{18}$

16 Saburo Matsumoto, "Japan's Voting Behavior in the United Nations," Japanese Politics: An Inside View, ed. Hiroshi Itoh (Itheca: Cornell University Press, 1973) 188209.

17 Ibid.

18 Haywar R. Alker, Jr. and Bruce M. Russett, World Politics in the General Assembly (New Haven: Yale University Press, 1965) 82-101. 
Their results also suggest transition away from the AA bloc to a strongly pro-Western position on East-West issues. And Japan continued a neutral position on North-South issues throughout the period.

Although the centering of foreign policy on the United Nations continued under Kishi's successor, Hayato Ikeda, after Ikeda, "U.N.-centered" diplomacy disappeared from public statements because of awareness of the limitation of the United Nations as the instrument of an effective collective security system. The frequent use of the veto in the Security Council, especially by the U.S. and USSR during the cold war, undermined trust in the U.N. as a bulwark of international peace and security. Moreover, during the 1960s when many developing countries joined the organization, the United States and the Western industrial countries lost control of the General Assembly, and thus the usefulness of resolutions declined. These changes made Japan suspicious about the effectiveness of the U.N. and diminished Japan's security expectations.

Yet, its U.N.-centered diplomacy in terms of conducting its diplomacy in line with the objectives and principles of the United States was not completely dead. For example, in 1971, the United Nations adopted a resolution recognizing the representation of the People's Republic of China and the following year Japan's diplomatic relations with China were normalized. 
By that time, Japan had effectively became a member of the Western bloc or OECD bloc. Steven Holloway, using factor analysis, studied votes in the U.N. General Assembly over a forty-year period. His study shows that in 1975 Japan was a part of the neutral cluster within the OECD bloc which is spread over a large group. ${ }^{19}$ Ogata, in her article, noted, since the late 1970s, Japan's strong tendency to vote with the Western bloc since the late 1970s. Despite Japan's pledge to promote world disarmament since its admission into the U.N., the government's voting position revealed Japan's priority in cooperating with western countries. one resolution, "non-use of nuclear weapons and prevention of nuclear war," had been put to a vote at every General Assembly since 1978. Japan abstained at the Thirty-Third and Thirty-Fourth General Assemblies but changed its vote to "against" to show solidarity with the Western nations after the Soviet intervention in Afghanistan. ${ }^{20}$

In 1978, the U.N. brought up a critical Asian issue, Vietnam's invasion of Cambodia. Asian countries were sensitive to Japan's actions in Asia for political and security issues. Japan, therefore, made careful political and humanitarian efforts through the framework of the U.N. Between 1979 and 1982, Japan cosponsored U.N. resolutions

19 Steven Holloway. "Forty Years of United Nations General Assembly Voting," Canadian Journal of Political Science, Vol.XXIII, No.2, June 1990: 279-296.

20 Ogata, Japan's New World Role 38 . 
outlining various conditions required for the peaceful settlement of the problem, including the withdrawal of foreign troops from Cambodia and self-determination for the Cambodian people. ${ }^{21}$ Japan also took a major role in humanitarian relief for the Indochinese refugees by providing funds to U.N. agencies such as United Nations High Commissioner for Refugees (UNHCR), World Food Programme (WFP), and United Nations Children's Fund (UNICEF).

Japan's U.N.-centered diplomacy came back stronger than ever in the official statements during the Gulf crisis when the United Nations became the center of attention in world politics. The Japanese government again stressed a U.N.centered diplomacy to gain support by the Japanese people for the collective action authorized by the United Nations against Iraq.

JAPAN AND THE U.N. IN THE CHANGING INTERNATIONAL ENVIRONMENT

Recent history has witnessed a changing climate in international relations. The soviet Union, the former communist superpower, and the Eastern Europe bloc collapsed between 1989 and 1991. Cooperation between Russia and the U.S. has become more apparent, and the number of member states of the U.N. has grown from 159 to 166. The possibility

21 Ogata, "The Changing Role of Japan in the United Nations," Japan's New World Role, ed. Joshua D. Katz and Tilly C. Friedman-Lichtschein (Boulder: Westview Press, 1985) $29-42$. 
that the U.N. might become an instrument capable of maintaining international peace and security has become a reality. The General Assembly, in adopting Resolution 44/23 without a vote in 1989, sought to strengthen the peacekeeping function of the U.N. ${ }^{22}$ This encouraged all states to use the U.N. framework to consult and cooperate on global issues.

At the same time, Japan itself has changed in light of its international responsibilities. As Japan has grown in global economic power, its financial contributions to the United Nations have expanded over the years. Along with its financial contribution, Japan has made great strides in securing representation in the various U.N. forums and in its principal organs. (TABLE I) of late, there has been increased involvement of Japanese in prominent positions in the United Nations. Examples include: Sadako Ogata, who heads the UNHCR, Yasushi Akashi, who leads the U.N. Transitional Authority in Cambodia (UNTAC), and Hiroshi Nakajima, who heads the World Health organization (WHO).$^{23}$

It is true that Japan still has fewer staff than most other major countries. For example, it has less than one tenth of the staff of the U.S and about half as many as

22 "A turning point in UN history: toward a search for common ground," UN CHRONICLE, Vol.XXII, No.1, March 1990: 411 .

23 "UN-Representative Japan," LOOK JAPAN, Vol.XXXIX, No.451, November 1993: 4-9. 
TABLE I

JAPANESE FINANCIAL AND PROFESSIONAL CONTRIBUTIONS TO THE U.N.

\begin{tabular}{|c|c|c|}
\hline year & $\begin{array}{l}\text { financial } \\
\text { contribution(US \$) }\end{array}$ & $\begin{array}{l}\text { professional } \\
\text { contribution }\end{array}$ \\
\hline 1970 & $5,316,227$ & 46 \\
\hline 1990 & $90,000,904$ & 91 \\
\hline
\end{tabular}

China. While a further progress is expected, there has been marked improvement in the number of staff members and important positions in the U.N. lead by Japanese representatives. Japan's growing role in the United Nations clearly reflects the expansion of its worldwide interests. From its rather narrow focus on the affairs of Asia in the 1950s, Japan's U.N. policy has come to encompass global needs and interests. 25

In the 1990s, a changing international climate, along with its economic power, caused Japan's foreign policy to reach a turning point, as it returned to U.N.-centered diplomacy. U.N.-centered diplomacy reappeared in the international crises in the Persian Gulf and cambodia. The U.N. Peace Cooperation Bill led Japan to face a dilemma between the interpretation of Article 9 of the Japanese

24 Source:The United Nations 1970, 1990, Administrative and Budgetary Questions; Budgetary Arrangement, Composition of the secretariat, Report of the secretary-General, UN Document.

25 Ogata, The United Nations and Japanese Diplomacy 164. 
Constitution and the obligations of U.N. member states under Article 42 and 43 of the U.N. Charter. The Bill did not pass the National Diet, although debate over it provided the opportunity to rethink Japan's foreign policy regarding military activities.

By the 1990s, the Japanese government gradually began to show its a constructive attitude for U.N. peace-keeping activities. During the Gulf crisis, Japan contributed $\$ 13$ billion for non-military use, such as aid to refugees. Yet, except for sending minesweepers after the cease-fire, Japan did not assist the multinational military effort against Iraq. Japan's uncooperative attitude created international criticism and an opportunity to rethink the work of the selfDefence Force. On June 1992, the Diet passed a law that ended the ban on sending SDF troops abroad, but limited such deployment to logistical and humanitarian support, monitoring elections, and providing aid in civil administration. ${ }^{26}$ within months, Japan joined in U.N. peacekeeping operations in Cambodia. The law was passed because of the international criticism of Japan's inaction during the Gulf crisis and because the Japanese government presupposed that such activities would be sponsored by the United Nations. These incidents led to increased expectations that the United Nations would function as the most reliable international

26 Kenneth B. Pyle, "Japan and the Future of Collective Security," Japan's Emerging Global Role, ed. Danny Unger and Paul Blackburn (Boulder: Rienner, 1993) 112. 
organization. Japan also seemed determined to avoid becoming isolated from the international community.

Furthermore, these incidents brought about reexamination of Japan's global position and its role in the U.N. There is no doubt Japan continued to place considerable emphasis on the economy, but other states started to expect a more active Japanese political role. Considerable talk surfaced during 1993 of giving Japan, as well as Germany, a permanent seat on the security council.

Along with Japan's enhanced role in the U.N., Tokyo has assumed a more prominent role within the G-7 which has became a global custodian for many international political and security issues. The G-7 began as the Group of Five (the U.S., Britain, West Germany, France, and Japan) in 1975, and several years later Italy and Canada joined the meetings. It was created to discuss global financial problems. During the 1980s, the G-7 summits added political and security matters to their agenda. Since then the summits have provided opportunities for member states to outline their own visions of foreign policy and to exchange ideas about international problems. ${ }^{27}$ Further, it may determine what positive step can be taken to create a new international order. For example, the G-7's 1991 declaration on arms control with respect to nuclear weapons, proliferation, arms production and trade, on

27 Yoshinobu Yamamoto, "The Role of the G-7 summit in the New International system," Japan Review of International Affairs, Vol.XII, No.3, Spring 1993: 161. 
which Japan had taken the initiative, was a major step forward. ${ }^{28}$ Thus Japan may use the meetings to coordinate its foreign policy, including policy toward the U.N., with other major nations beyond the context of its bilateral relationship with the United States.

Overall, Japan's fundamental attitude toward the United Nations has not changed since its admission to the organization. Japan has had high expectations, and trusted that the United Nations will play a central role in the maintenance of international peace and security, as well as in the management of other global issues. In addition to respect for the United Nations, the Japanese government believes that it is beneficial for Japan to use the framework of the United Nations. Former Liberal Democratic Party Secretary General Ichro ozawa reported, after an Asian trip in May 1992, that "Asia is not concerned about Japan's playing an active role within the framework of the U.N."29 It seems that the United Nations has become one solution to a dilemma that Japan faces as its growing international political role runs up against its uneasy relationship with Asian countries that have always worried about Japan's

28 Takashi Inoguchi, Japan's Foreign Policy in an Era of Global Change (New York: St. Martin's Press, 1993) 152.

29 "No concern in Asia: Ozawa to Return Home from Foreign Trips Today; Response Obtained Regarding PKO Co-operation," Tokyo Shinbun, May 7 1992, cited by Eugene Brown in "The Debate Over Japan's strategic Future," Asian Survey, XXXXIII, No.6, June 1993: 543-559. 
intentions in Asia.

Given the above reasons, Japan is likely to continue to use the United Nations as an instrument of foreign policy and bind its relationship with the U.N. more tightly. Yet Japan will continue struggling with its mixed identity: as a member of the West, and as a member of the Asian community. 
CHAPTER II

JAPAN'S FOREIGN POLICY BETWEEN 1988 AND 1992

ACTORS IN JAPAN'S FOREIGN-POLICY MAKING

Foreign policy is a set of guides or general principles by which a state governs its reaction to the international environment. It can be found in a government's formalized decisions. In Japan, governed under a parliamentary system, a prime minister is the key figure in all foreign policy decisions. The principal foreign affairs specialist in the government is a foreign minister (vice-minister) who heads the administrative department concerned with foreign policy and is the principal official adviser to the head of government. The central foreign-policy coordinating and administrative unit is the Ministry of Foreign Affairs, which includes a policy planning staff charged with overall evaluation and planning of basic foreign policy positions. Because a major emphasis of Japan's foreign policy has been on economic matters, the Ministry of Finance and the Ministry of International Trade and Industry also are involved in policy-making.

The Diet is the only state law-making body and can pass any laws consistent with the Constitution. Thus, the Diet ought to be able to exercise substantial control over foreign 
policy by enacting laws. For example, in 1991 the U.N. Peace Cooperation Bill was rejected after deliberation in the 119th session of the Diet. Yet, despite the Diet's constitutional role, the opportunities to participate in the shaping of foreign policy are limited and most important legislation is initiated by the cabinet. ${ }^{30}$

The prime minister and the cabinet have access to the resources of the prime ministerial staff, which gives them effective control of policy making. The Cabinet councilors' office on External Affairs is formally responsible for "providing overall coordination on important items engaging the cabinet and for providing the overall coordination needed to preserve the unity related to policies of each administrative part, with particular emphasis on items related to foreign relations" (Cabinet Law)..$^{31}$ However, the head of the office is seconded from the Ministry of Foreign Affairs. The Ministry retains substantial control over the coordination of policy. 32

In sum, the Ministry of Foreign Affairs is an integral part of the policy-making machinery, the working out

${ }^{30}$ Shuzo Kimura, "The role of the Diet in Foreign Policy and Defence," The Japanese Diet and the U.S. Congress, eds. Francis R. Valeo and Charles E. Morrison (Boulder: Westview Press, 1983) 99-111.

31 Kenji Hayao, The Japanese Prime Minister and Public Policy (Pittsburgh: University of Pittsburgh Press, 1993) 170.

32 Ibid., 171. 
technical details, and administering policy outputs. Given the structure of policy making, this chapter will review Japan's foreign policy by concentrating on the Diplomatic Bluebook, which is a report published annually by the Ministry of Foreign Affairs. The "Bluebook" includes official speeches by prime ministers and foreign ministers at the National Diet, the U.N. General Assembly, or other important meetings.

OVERVIEW OF JAPAN'S FOREIGN POLICY

The basic foreign policy of the Government of Japan between 1988 and 1992 has been one of contributing to international peace and prosperity while ensuring Japanese security and economic well-being. It has been based on the realization that Japan is a member of both the free market and the democratic world, and at the same time an AsiaPacific nation. ${ }^{33}$ Japan is the only Asian nation in the industrialized western camp. As a member of the Asian community, it has explained East-West relations from the Asian point of view at summit meetings and on other occasions in an efforts to deepen other nations' understanding. From the standpoint of maintaining security for the entire West, Japan has consulted and cooperated closely with the United states and other western nations in arms control and

33 Ministry of Foreign Affairs, Japan. Diplomatic Bluebook 1988 (Tokyo: The Japanese Foreign Ministry, 1988) 3. 
disarmament and other issues.

Japan believes that exercising all due vigilance in the cause of security is prerequisite to maintaining the country's independence and prosperity and protecting the lives and property of the people, and that these objectives must be the basis of any foreign policy. ${ }^{34}$

To pursue its own security, maintaining a close relationship with the United States is vital to Japan, given the fact that the peace and stability of the international community rest basically upon the balance of power and deterrence. The United states' deterrent force is indispensable to ensuring Japan's own security, and the security arrangements with the United states are the cornerstone of Japanese national security. At the same time, Japan needs to have an adequate defense capability of its own. Under its Peace Constitution Japan is thus striving to develop a moderate yet effective posture, never to become a military power that would threaten its neighbors, to adhere to the principle of civilian control, and to observe the Three Non-Nuclear Principles. ${ }^{35}$ Together with the security arrangements with the United States, Japan hopes that the efforts to enhance its defense capability will contribute to

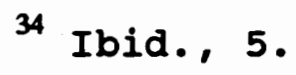

35 The Three Non-Nuclear Principles--not to produce, possess, or allow the entry of nuclear arms--declared by Prime Minister Eisaku Sato in 1967 and adopted by the Diet as a resolution in 1971. 
maintaining the security of the free market and democratic community and to peace and stability in Asia. ${ }^{36}$

To Ensure its security, Japan also seeks to play an active role in the maintenance and development of the international order. Former Prime Minister Noboru Takeshita showed his government's intentions at the 112 th session of the National Diet.

The international climate today is still extremely fluid, fraught with numerous issues including the further stabilization of East-West relations, the solution of regional conflicts, sustained world economic growth, and stability and development in the developing countries. within this context, it is important that Japan, aware of its position as a mainstay of the international order, actively play a larger role and accept larger responsibilities from the global perspective. ${ }^{37}$

In dealing with these international issues, the Government of Japan emphasized three areas -- cooperation for world peace, enhanced Official Development Assistance (ODA), and international cultural exchanges. These became known as the three pillars of the International cooperation Initiative. ${ }^{38}$

By its broad and ambiguous call for cooperation towards world peace, the Government of Japan meant a more vigorous and visible participation in international activities. Given a number of destabilizing factors such as regional problems

36 Ministry of Foreign Affairs, Japan. 1988. 6 .

37 Policy speech by Prime Minister Noboru Takeshita to the 112th Session of the National Diet, January 25, 1988.

38 Ministry of Foreign Affairs, Japan. 1988. 5. 
in the former Yugoslavia, cambodia, and elsewhere, and even international terrorism, the government wished to show the recent growth in Japan's national capabilities by its contributions to humanitarian activities under international frameworks.

Japan intends to contribute actively in this area by making diplomatic efforts to build a solid foundation for peace, strengthening its international cooperation against terrorism, enhancing and diversifying its capital and other cooperation for peacekeeping activities, providing personnel for peacekeeping activities under the United Nations and other international auspices, strengthening its refugee relief, providing post war reconstruction assistance, and other measures. ${ }^{39}$

The second objective of Japanese foreign policy -enhancing ODA -- is the field in which visible progress has already been made. There has been a sharp increase in the other industrialized countries' expectations in this regard, in keeping with the dramatic growth of the Japanese economy. Realizing that Japan has an important international responsibility to expand its ODA for the purposes of contributing to economic and social development, raising living standard, and enhancing welfare in the developing countries, according to the government, Japan is supposed to implement its ODA in keeping with the generally accepted ideals of interdependence and humanitarian considerations. In

39 Ministry of Foreign Affairs, Japan. Diplomatic Bluebook 1989 (Tokyo: The Japanese Foreign Ministry, 1989) 15-16. 
addition to the above potentially positive means of ODA, it helps Japan to mitigate economic friction with trade partners.

The Japanese government announced that under the Fourth Mid-Term Target, Japan raised its ODA disbursements for the five years starting in 1988 to more than $\$ 50$ billion. This program also seeks to raise the ratio of its ODA to GNP: to expand the grant portion of its aid to enhance debt relief for the poorest countries of the world; to expand technical assistance, including the strengthening of provisions allowing foreign students to study in Japan; to promote cooperation through international organizations; and otherwise to enhance the quality of Japan's ODA. ${ }^{40}$

Promoting international cultural exchange is the third objective task for Japanese foreign policy. Japan has formed broad and intensive relationships with other countries of the world, but according to the government, friction between it and other nations often stems from misunderstanding or inadequate understanding of one another's culture and social practices. The government came up the solution that Japan needs to increase cultural exchanges in a broad sense because they transcend the differences of political system and value to lay the foundations for mutual understanding among peoples and because they promote smoother economic and political

40 Japan Echo. The Japan of Today (Tokyo: The International society for Educational Information Inc., 1993) 28-29. 
relations. ${ }^{41}$ The idea of emphasis on cultural exchange derives from its belief of cultural relativity that there is difference between Japan and other countries in their way to react international matters, and there is no way to compare based on one-side judgement.

The collapse of the soviet socialist bloc in Europe in 1989 did not change Japan's basic stance. Japan welcomed the changes in the political situation in East Europe which appeared to show that former communist dominated people desired a free market economy and democratic government. ${ }^{42}$ However, in the Asia-Pacific region, tension and instability remain on the Korean Peninsula, in Cambodia, and elsewhere. Japan was expected to make efforts for peace in the region as well as in the other regions.

In the area of cooperation for peace, the Government of Japan has recognized that its cooperation was not fullparticipation in the international community. Japan gradually showed its intention to take steps to improve the arrangements for dispatching personnel overseas as well as continuing financial contributions under the framework of the United Nations. ${ }^{43}$ In 1989, for example, Japan sent a group of 27 people to Namibia to supervise that country's election

41 Ministry of Foreign Affairs, Japan. 1988. 10. at the 188th Session of the National Diet, March 2, 1990. 43 Ibid. 
for a Constituent Assembly. In February 1990, it also dispatched personnel for the observation of the election in Nicaragua.

Iraq's 1990 invasion of Kuwait, the so-called Gulf Crisis, was a major challenge for Japan's foreign policy and instigated a change in it. Tokyo realized its inability to give quick responses to such emergencies. It made a financial contribution of $\$ 13$ billion to support the multinational forces and the affected countries in the Gulf region. Japan sent seven groups, with a total of 66 persons, from the Japan Disaster Relief Teams to the Gulf region immediately after the cease-fire to deal with environmental destructions and to assist refugees. It also dispatched minesweepers of the Maritime Self-Defense Forces to the Gulf to assist in removing mines after the cease-fire.

Japan's limited presence was a subject of criticism. The critics pointed out that Japan needed policies, capabilities, and legal preparations as well as public consensus to take on a larger international role such as peacekeeping. The criticism largely stemmed from Japan's human resource contribution: the deployment of the Self-Defense Forces for U.N. Peace-keeping operations, or of disaster relief operations carried out by the Japan Disaster Relief Teams, can only be approached after lengthy deliberations in the Diet.

The debate on what and how much Japan should do for 
world peace and security continued. The Japanese government prepared a Peacekeeping Operations (PKO) bill, which authorized the dispatch of the SDF to U.N.-sponsored peacekeeping activities. Submitted in an extraordinary session of the Diet at the end of 1990, the bill gave greater legitimacy to the long-standing desire of conservatives to remove the constraints imposed by Article 9 of the Japanese constitution. The constitution had been interpreted earlier in the postwar period as allowing the maintenance of defensive military forces so long as they were not dispatched abroad. The prohibition on overseas dispatch included participation in U.N. or other multilateral military actions and even U.N. peacekeeping actions. The opposition parties, the majority of the public, and even some in the IDP believed the dispatch of SDF personnel overseas would violate Article 9 of the Japanese constitution. ${ }^{44}$

Regarding the extension of activities of the selfDefense Forces, Japan decided to adhere to its Peace Constitution as a basic foreign policy stance. At the 45 th Session of the General Assembly of the United Nations in 1990, Foreign Minister Nakayama stated:

Since the second World War, Japan has developed a foreign policy whose object, above all else, is peace and, inline with its Peace constitution, has restricted its military activities entirely to defense, seeking to resolve differences with other nations through

44 Edward J. Lincoln. Japan's New Global Role (Washington, D.C.: The Brooking Institution, 1993) 228-231. 
discussion. The spirit underlying Japan's Constitution is based on the principle of the peaceful settlement of disputes that is embodied in the United Nations Charter. Thus ever since being admitted to membership, Japan has made the United Nations an extremely important part of its foreign policy. Japan firmly resolved not to become a military power that could pose a threat to other nations, to steadfastly uphold its three non-nuclear principles and to contribute to world stability through peaceful means.

The bill was abandoned before the completion of its deliberations. However, due to the nationwide debate, including the Diet session, a perception had emerged that it was indispensable for Japan to make sufficient contributions to international peace and security.

In September 1991, the Government submitted a new bill to the Diet concerning cooperation with U.N. Peacekeeping Operations with a view to establishing a domestic framework for participation in U.N. peacekeeping and humanitarian international relief activities on a full-fledged scale. ${ }^{46}$ Twenty months of debate in the National Diet focused on the conformity of the bill with the constitution, the necessity of Diet approval, the meaning of U.N. command, and the basic principles of participation in the U.N. Peacekeeping

45 Statement by Foreign Minister Taro Nakayama at the 45th Session of the General Assembly of the United Nations, September 25, 1990 .

46 Ministry of Foreign Affairs, Japan. Diplomatic Bluebook 1992 (New York: The Japanese Foreign Ministry, 1992) 52-53. 
Operations. $^{47}$ on June 15, 1992, the bill finally passed and authorized the dispatch of up to 2,000 members of the SDF to U.N.-sponsored peacekeeping activities. However, the role of SDF personnel in the activities was limited to noncombat support functions, including logistical support, medical assistance, and election monitoring carried out by peacekeeping missions under U.N. command. ${ }^{48}$ In this sense, Japan's military presence had little to do with the appropriate response to the crisis in the gulf.

overall, Japan believes that it can best contribute to the cause of world peace, and in a manner consistent with its Peace Constitution, by participating in United Nations activities. Japan also realized that it must further strengthen its machinery for conducting foreign policy in order to appropriately cope with the turbulent international situation in the pursuit of its diplomatic interests.

In the post-cold war era, hope was widespread for new

47 The five principles: 1) Agreement on a cease-fire shall have been reached among the parties in the conflict. 2) The parties in the conflict, including the territorial state(s), shall have given their consent to deployment to the peacekeeping forces and Japan's participation in the Force. 3) The peacekeeping force shall strictly maintain impartiality, not favoring any party in the conflict. 4) Should any of the above guideline requirements cease to be satisfied, the Government of Japan may withdraw its contingent. 5) Use of weapons shall be limited to the minimum necessary to protect the personnel's lives.

48 Tsuneo Akaha, "Japan's Security Policy in the Posthegemonic World:Opportunities and Challenges," Japan in the Posthegemonic World, eds. Tsuneo Akaha and Frank Langdon (Boulder: Rienner, 1993) 103. 
order for global peace and stability. Prime Minister Kiichi Miyazawa expressed Japan's determination about a new world order in 1992 at the National Diet;

The whole world is today watching to see what role Japan will play and what responsibilities Japan will fulfill in light of the influence its considerable economic strength give it. This year 1992 is truly a year in which Japan mettle will be tested. It is essential that we bring our collective wisdom to bear in taking an active, independent, and creative part in building the new order for peace and proving ourselves worthy of this historic mission. ${ }^{49}$

He also said that peace is basic to the new world order, and true peace is more than the simple absence of war but rather must be a condition promising human happiness. ${ }^{50}$ According to Miyazawa, the quest for a new world order is therefore an effort to create an international society of respect for peace and democracy in which people enjoy prosperity based on market principles.

The Gulf Crisis demonstrated how important it is that conflicts be resolved peacefully through international cooperative efforts led by the United Nations. Japan believes that the United Nations has an important role to play in the post-cold war international community. Japan has respected the United Nations as a central focus of its foreign policy. since its election, in 1991, as a non-permanent member of the

49 Policy speech by Prime Minister Kiichi Miyazawa at the 123rd Session of the National Diet. January 24, 1992.

50 Ibid. 
U.N. Security Council, Japan has been in a position to play a central role in debates on international peace and security. And Japan has given serious thought to proposals for strengthening and reorganizing the United Nations, including enhanced trust and effectiveness for the security council. 51

In sum, the Government of Japan has emphasized its dual identity: as a member of the Western camp, and of the Asian community. It adheres to pacifism, and since 1988, has aimed to play an active role furthering the principles of the three pillars of International Cooperation Initiative.

\section{EAST-WEST RELATIONS AND DISARMAMENT ISSUES}

As a member of the industrialized Western camp, Japan welcomed the improved climate of relations between the U.S. and the Soviet Union that developed during the post-cold war era, and showed readiness to assisting in achieving a new order in Europe. Japan willingly helped the economic reconstruction of Eastern Europe. In May 1990, Japan agreed to establish the European Bank for Reconstruction and

51

Since 1991, various proposals were made by former U.N. secretary-General Javier Prez de cuellar and the current Secretary General Boutros-Ghali. For example, Boutros-Ghali announced the restructuring of the U.N. Secretariat, including the streamlining of five political-related departments, such as the office for Political and General Assembly Affairs and Secretariat Services; transforming the office of Special Political Affairs into the Department of Peace-keeping operations; integration of the five economic development-related departments; Department of Humanitarian Affairs. 
Development (EBRD) with the United States, EC members, the Soviet Union, East European countries, and European Economic Community (ECC) and European Investment Bank (EIB). 52 Japan participated in the organization with an approximate 8.58 stakes, a level of participation second to the U.S. and the same as the U.K., France, Germany, and Italy. In addition, Japan provided technical assistance when it received the Soviet Union's Economic Reform Study Mission in November 1989, and again in April 1990.

With the general progress in East-West relations, Japan's expectations of improvement in Japan-Soviet relations increased. Japan hoped to finally resolve the issue of the Northern Territories. Japan has long claimed islands in the vicinity of Hokkaido which the Soviet occupied since the end of World War II. The disposition of the territories has blocked a final USSR/Japan peace treaty. Japan emphasized the importance of the settling the issue, and called on the Soviet Union to enter into negotiations. Yet the Soviet Union denied Japan's requests, and insisted that an improvement in bilateral relations would get nowhere if Japan attached the issue of the Northern territories as a prerequisite. ${ }^{53}$

In 1988 the positive influence of the improvement of U.S.-Soviet relations appeared in such areas as strategic

52 Ministry of Foreign Affairs, Japan, Diplomatic Bluebook 1990 (Tokyo: The Japanese Foreign Ministry. 1990) 29-30.

53 Ministry of Foreign Affairs, Japan. 1988. 230. 
nuclear weapons and other arms control and disarmament issues, and regional conflicts in Afghanistan and elsewhere. The INF (Intermediate-Range Nuclear Forces) treaty, which aimed at abolishing intermediate-range nuclear weapons on a global scale, was signed in December 1987 and went into force in June 1988. An agreement on withdrawal of Soviet troops from Afghanistan was also signed in Geneva in April 1988. However, while there were several noteworthy developments for improving East-West relations, the state of confrontation and tensions still existed. Of such trends, Minister of Foreign Affairs Sousuke Uno, addressing the 112th Session of the National Diet, said:

Japan must continue supporting the efforts of the United states as a member of the Western camp. At the same time, Japan will continue to make every effort in the third special session of the General Assembly devoted to disarmament to be convened at the end of May and other forums to further promote international efforts for substantive progress in disarmament and to lower level of armaments step by step in balance. ${ }^{54}$

It is true that the relationship between the United States and the Soviet Union is an important factor for arms control. However, for disarmament to contribute to true world peace and stability, the various countries of the world will have to strive to cut back on weapons through multilateral negotiation. With this point in mind, Japan has joined to the

54 Foreign policy speech by Minister of Foreign Affairs Sousuke Uno at the 112th Session of the National Diet, January 25, 1988 . 
disarmament talks being carried on under the auspices of the U.N. Geneva Conference on Disarmament, and has called for the promotion of truly effective arms control and disarmament, such as the proposal of a step-by-step approach to nuclear testing issues.

On June 1, 1988, Prime Minister Takeshita delivered a speech at the Fifteenth Special Session of the U.N. General Assembly and elucidated his thoughts on disarmament and arms control. Takeshita said that Japan, as the only victim of the atomic bomb, is ready to work for the ultimate elimination of nuclear weapons and other weapons. 55 In addition to achieving nuclear disarmament, he suggested preventing an increase in the number of nuclear-weapons states, the realization of a nuclear test ban, the prevention of chemical weapons, and implementing conventional arms control. Although the process to complete disarmament and arms control will be difficult and lengthy process, Takeshita in his statement expressed a commitment to Japan's longstanding pacifist position.

With the end of cold war, the issues of arms control and disarmament have met remarkable improvement. The U.S.-Soviet summit meeting held on June 1990, issued a document of agreement to the principle's of the strategic Arms Reduction Talks (START). Japan maintains as its basic stance that it actively participates in international efforts in arms

55 Statement by Prime Minister of Japan, Noboru Takeshita, at the Fifteenth special session of the U.N. General Assembly, June 1, 1988. 
control and disarmament. According to the Ministry of Foreign Affairs, arms control and disarmament should proceed in such a manner that the arsenals of countries concerned are reduced in a balanced way and with no loss of their deterrent effects, thereby improving the security of countries concerned and contributing to world peace and safety. ${ }^{56}$ Based on this position, Japan has been supporting efforts of the United States and other Western nations regarding START and the Conventional Forces in Europe (CFE). At the same time Japan has been involved with other wide-ranging disarmament issues, especially, the issue of nuclear weapons.

with the background of the changes, the problems of the proliferation of weapons of mass destruction and transfer of conventional weapons from the North to the South has come to be clearly recognized as a destabilizing factor in the world. It was made even more clearly by Iraq's invasion of Kuwait. since Japan takes a unique stance in this field, which includes the adoption of the "Three Non-Nuclear Principles" and the "Three Principles on Arms Exports" ${ }^{57}$ " it believes that Japan can contribute more to the world than any other

56 Ministry of Foreign Affairs, Japan. 1990. 61.

57 The Three Principles on Arms Export--which disallowed exports to (1) Communist bloc countries, (2) countries subject to embargoes on arms export under the U.N. Security Council's resolutions, and (3) countries engaged or likely to be engaged in an international conflict--was declared by Prime Minister Eisaku Sato in 1967, and Prime Minister Miki, in 1976, extended the prohibition of arms export to all other countries as well, and in addition prohibited the export of weapon-related technology and production equipment. 
nation in this respect.

Japan's concerns about the problems of nuclear proliferation have been heightened by the Gulf crisis and North Korea's refusal to conclude safeguards agreement with the International Atomic Energy Agency (IAEA). Japan constantly urged North Korea to conclude and implement the full-scope safeguards agreement with the IAEA. Japan also has continuously asked countries which are not yet parties to the Nuclear Non-Proliferation Treaty (NPT) to accede to the Treaty.

In March 1991, after the Gulf Crisis, Japan announced its basic policy on the problems of international transfers of conventional weapons and missiles and the proliferation of weapons of mass destruction in a report titled "the Japanese Near-term Responses to the Problems in the Middle East" in March 1991. In the package, Japan proposed the establishment of a register of international arms transfers under the auspices of the United Nations. At the United Nations Kyoto Conference on Disarmament in May 1991, held at the initiative of Prime Minister Toshiki Kaifu, he announced in his speech that Japan would submit a draft resolution on the establishment of U.N. register system of international arms transfers to the U.N. General Assembly in the Autumn of 1991.58

Japan also played an active role in sponsoring the Tokyo

58 Ministry of Foreign Affairs, Japan, 1991. 103-104. 
Workshop on Transparency in Armaments in June 1992, and the U.N. Conference on Disarmament Issues in June 1992, held in Hiroshima.

\section{THE MIDDLE EAST PEACE PROBLEM}

Japan has usually taken the position that peace in the Middle East must be fair, lasting and comprehensive, and that such a peace must be achieved by fulfilling the following conditions: 1) Israel's withdrawal from all of the Arab territories it occupied as a result of the 1967 War; 2) recognition of the rights of Palestinians to selfdetermination, including the establishment of an independent Palestinian state; and 3) recognition of the right of Israel to exist. 59

The Middle East is a strategically important region as a major crude oil supply source. Japan not only relies on the region for nearly 708 of its crude oil needs but also has exceedingly close relations with Middle East countries as its trade partners and host countries of its investment. Japan has continued diplomatic exchanges and has provided a level of financial support and food aid second only to the United States through the United Nations Relief and Works Agency for Palestinian Refugees (UNRWA). In fiscal 1988, based on the peace treaty between Egypt and Israel, Japan decided to devote $\$ 1$ million to the Multinational Force and Observers 
stationed on the sinai peninsula and to provide $\$ 1$ million cash assistance to the socio-economic development of the West Bank and Gaza Strip region by establishing a Japan-Palestine development fund under the United Nations Development Program. ${ }^{60}$

Japan considered the problem of Iraq's invasion of Kuwait as a critical issue. First, Iraq made the invasion in flagrant violation of the United Nations Charter. Japanese readers claimed that Iraq's invasion needed to be stopped with firm determination because it had defied international order and threatened global peace and security. Second, as a new order of international politics was being explored as a result of the significant changes in East-West relations, it was important for Japan, which was in a position to assume international responsibility, to play an active part in international efforts to correct such injustice. Third, as the Gulf area accounts for 65 of the world oil reserves, the area's stability remained essential in securing a stable energy supply.

Because of the above reasons, Japan strongly denounced Iraq's invasion of Kuwait. In August 29, 1990, Japan announced measures of towards contributing to the restoration of peace in the Middle East. According to the measures: 1) Japan would cooperate in the transportation of goods such as food, water, and medical supplies by chartering civil 
aircraft and ships; 2) Japan would take necessary measures to provide materials and equipment in such areas as heat protection and water supply; 3) Japan would establish a system whereby a medical team of about 100 persons could be urgently dispatched. ${ }^{61}$ In order to make an effective contribution to international efforts being made by the United States, and many countries in Europe, Africa and Asia, Japan decided to provide a wide range of assistance amounting to $\$ 1$ billion. In addition, Japan announced economic aid amounting to $\$ 2$ billion for neighboring countries in the Gulf area which face serious economic difficulties, along with more than $\$ 22$ million in aid for refugees. ${ }^{62}$

In relation to the issue of the peace in the Middle East, Japan decided to extend indirect support for promoting peace in the region, and took some measures as the first step towards bringing more balance Japan's relationship between Arab countries and Israel. Japan stepped up political dialogue with Israel and the PLO, which included the visit of PLO chairman Arafat to Japan in October 1989, the visit of Israeli Foreign Minister Arens to Japan in November, the Japan-Israel working level meeting in February 1990, and the Japan-PLO meeting in April. On the relationship with Israel, which had been relatively weak, the Government of Japan sent Deputy Vice Minister for Foreign Affairs, Hisashi Owada, to

61 Ministry of Foreign Affairs, Japan. 1991. 53.

62 Ibid., 50-54. 
Israel in January 1991 and Foreign Minister Taro Nakayama in June. ${ }^{63}$ The dialogue between the two countries has been intensified and Japan decided to enhance its assistance to the Palestinian in the occupied territories.

\section{HUMAN RIGHTS ISSUES}

Japan believes that respect for fundamental human rights is not only an important goal in itself, but also contributes to peace and stability in the world. ${ }^{64}$ And Japan also believes that it is essential to improve the conditions of poverty and other social problems affecting the countries. Such beliefs stem from Japan's contention that the country's peace and prosperity today are founded on its consistent respect for fundamental human rights, freedom, and democracy during the postwar period. From this basic stance, it endeavors to actively promote human rights and fundamental freedoms by engaging in activities at various U.N. organizations. Japan has worked as a member of the United Nations Commission on Human Rights for three consecutive terms since 1982, and was re-elected in 1990 .

There is a strong tendency to politicize human rights issues. The refugee problem is one example. Japan considers the refugee problem in Afghanistan, Africa, Indochina, Palestine and other region of the world as political and also

63

Ibid. , 57.

64 Ministry of Foreign Affairs, Japan, 1988, 75. 
humanitarian problems. Japan participates actively in discussion on refugees and contributes to solving the refugees problem by providing aid through international forums related to refugees. Japan has provided about $\$ 950$ million in aid to refugees all over the world through UNHCR, UNRWA, World Food Program(WFP), International Committee of the Red cross(ICRD) and others.

on the issue of South Africa, the Japanese government adopted and continued to maintain various kinds of sanctions, against South African in line with its strong opposition to apartheid. To support people in south Africa who were victimized by apartheid, Japan began making donations in 1987 to projects designed to support medical treatment and education.

Japan sees cooperation to help refugees as part of its "cooperation for peace," and has positively contributed to international efforts toward the solution of refugee problems in the world. In January 1991, Professor Sadako ogata took up the post of the eighth United Nations High Commissioner for Refugees -- the first woman to assume the post. Japan takes Ogata's appointment as "the high assessment given by the world to positive Japanese contributions to the refugee problem. 165

In 1991, Japan contributed a total of $\$ 160$ million to assistance to displaced persons from Iraq and Kuwait, $\$ 100$ 
million to Kurdish refugees, $\$ 10$ million to Palestine refugees, and $\$ 8.12$ million to African refugees.

For Japan, as a member of the $G-7$ and as a responsible member of the international community, it has become increasingly important to take actions based on the basic philosophy that human rights are a universal value for all mankind and are the basis for world peace and stability. As a part of a policy of respect for human rights, the ODA Charter, adopted at a cabinet meeting in June 1992, includes promotion of human rights as one of its principles in executing the ODA. Full attention is to be paid to efforts for promoting democratization and the securing of basic human rights in providing ODA to developing countries. ${ }^{6}$

Since the latter half of 1991, new problems concerning refugees and displaced persons have emerged in such countries as the former Yugoslavia and Myanmar as a result of regional conflicts which became serious in the post-cold war era. For displaced persons in the former Yugoslavia in consequence of the armed conflicts among the ethnic groups of Muslims, Serbians, and Croatians, in 1992, Japan contributed approximately $\$ 24.51$ million. For 250,000 Muslim refugees from Myanmar in Bangladish, it responded to UNHCR's appeal with $\$ 1$ million in March 1992. Japan has played a leading role in the international efforts for providing financial assistance.

66 Ministry of Foreign Affairs, Japan, 1992, 61-62. 
ECONOMIC DEVELOPMENT IN DEVELOPING COUNTRIES

In 1987, there was little improvement in the economic environment surrounding developing countries. Latin American countries were suffering from huge external debts, and subSaharan African nations and other less developed countries (LDCs) were unable to overcome the fragility of their economic foundations. only the Newly Industrialized Economies, especially in Asia showed relatively favorable performances.

According to World Bank statistics, the external debt of developing countries was estimated to have reached $\$ 1.2$ trillion by the end of 1987 . Heavy external debt repayment burden was proving to be a major problem not only for debtors but also for the world economy. To break such deep debt problems Japan believed that it was important to take into account self-help efforts on the part of debtor countries. ${ }^{67}$ The self-help efforts was to be done through the promotion of economic adjustment policies in cooperation with the IMF, World Bank, and other international commercial banks, which extend support in such forms as debt relief and provide fresh loans on a case by case basis.

In order to promote the flow of funds to indebted countries, Japan decided in 1987 to recycle completely untied government and private funds to developing countries 
amounting to more than $\$ 20$ billion over a three year period, and to increase grants including about $\$ 500$ million nonproject aid to sub-Saharan African and other LDCs. ${ }^{68}$ Furthermore, Japan believes that for the economic development of recipient developing countries, overseas direct investment contributes best to solving the problem of accumulated external debts; as the flow of funds in the form of direct investment does not incur further indebtness. ${ }^{69}$

The most noteworthy of Japan's contribution to developing countries has been ODA. According to the government, Japan has been increasingly extending its economic and technical assistance to developing countries based on humanitarian considerations. Already the second largest economic power in the free world, in 1988 Japan increased its ODA budget by 8.88 to about $\$ 10$ billion, surpassing the United States which earmarked $\$ 9$ billion, and became the world's largest ODA donor. ${ }^{70}$ In order to make its assistance more effective, Japan emphasized the quality of ODA as well as the quantity. According to the government, it extends loans as "soft" as possible -- meaning as close to grants as possible in terms. The Forth Medium-Term Target

68 Ministry of Foreign Affairs, Japan, 1988, 103-104.

69 Ibid., 97.

70 Ibid., 108 . 
also clearly calls for qualitative improvement. ${ }^{71}$ Japan tries to makes ODA effective by the globalization of assistance. Japan's ODA has been criticized because of its emphasis on the Asian region. In 1987 the distribution of Japan's ODA was $\$ 3,416$ million $(658)$ in assistance to Asia, $\$ 516$ million (108) to Africa, $\$ 418$ million (8z) to Latin America, $\$ 526$ million (10\%) to the Middle East, and $\$ 68$ million (1\%) to oceania. ${ }^{72}$ In 1988 , it was $\$ 4034$ million (63\%) to Asia, $\$ 884$ million (148) to Africa, $\$ 583$ million (98) to Middle East, $\$ 399$ million $(6 \%)$ to Latin America, and $\$ 93$ million (1\%) to oceania. ${ }^{73}$ To increase the proportion of its ODA disbursement to the regions other than Asia, Japan has expanded aid to Africa. Yet the inclination to Asia of Japan's ODA disbursement has not been changed.

In order to make its assistance more effective, Japan has also been promoting the formulation of country-by-country

71 The Fourth Medium-Term Target (points) -- 1) increase the total amount of ODA more than twice from $\$ 25$ billion in the preceding five years to over $\$ 50$ billion in the current five-year period (1988-1992), and improve the ODA/GNP ratio; 2) increase grant aid to and expand debt relief measures for the Least Less Developed Countries (LLDCs); 3) expand technical cooperation, and strengthen ties with nongovernmental organizations (NGOs); 4 ) increase personnel contribution to international organizations, and promote technology transfer to developing countries; 5) promote qualitative improvement of yen-dominated loans and general use of united loans; 6) increase aid staff, improve the implementation system, and promote coordination with private sector activities.

72 Ibid., 110.

73 Ministry of Foreign Affairs, Japan, 1989, 91. 
assistance plans. The government, for example, sends a comprehensive economic cooperation research mission to aid recipient countries. Since Japan emphasizes the self-help efforts of developing countries as its basic philosophy of aid, it maintains a policy of providing ODA only upon requests. However, according to the government, this does not mean that Japan reacts passively to the requests. It means that through policy dialogue with developing countries, Japan communicates the need to make their best effort to implement the aid with maximum effectiveness and benefit. In addition, Japan decided to take global problems into consideration. The Ministry of Foreign Affairs signaled a shift in the Japanese approach by conditioning aid upon the adoption of appropriate development strategies, limiting of military spending, and progress toward democratization. ${ }^{74}$

In addition, Prime Minister Kaifu stipulated that Japan will pay close attention to implementation of ODA by the recipient countries regarding: 1) trends in military expenditure; 2) trend in development, production, etc. of weapons of mass destruction such as atomic weapons and missiles; 3) trend in the export and import of weapons; and 4 ) efforts for promoting democratization and introduction of a market-oriented economy and the guaranty of basic human

74 Danny Unger, "Japan's Capital Exports: Molding East Asia," Japan's Emerging Global Role, ed. Danny Unger and Paul Blackburn (Boulder: Rienner, 1993) 155-170. 
rights and freedom. ${ }^{75}$ As to official bilateral debts, Japan is to apply debt relief schemes with due consideration of the funds required by the debtor countries' economic reconstruction.

In June 1992, the Japanese government adopted in a Cabinet Meeting Japan's ODA Charter. This is the first comprehensive document that outlines the philosophy and principles under which Japan's aid is to be extended, its priority regions and issues, and points of consideration in its implementation. The basis of Japan's aid is described in this ODA Charter as being "support for the self-help efforts of developing countries toward economic take-off," as based on the following: "humanitarian considerations," recognition of "interdependence in the international community" and "environmental conservation. "76 "Humanitarian considerations" refers to the fact that it is impossible to ignore the reality that many people are still suffering from famine and poverty in the developing countries. The emphasis on "interdependence in the international community" means that the stability and further development of the developing countries are essential to the peace and prosperity of the world. "Environmental conservation" is also a task, which all countries must tackle together. As for regional priorities, the ODA Charter stated that the regional priorities of

\footnotetext{
75 Ministry of Foreign Affairs, Japan, 1991, 131.

76 Ministry of Foreign Affairs, Japan, 1992, 35-36.
} 
economic assistance will continue to be placed on Asia, the area with which Japan has had close relationships in historical. geographical, political and economic terms. ${ }^{77}$

\section{GLOBAL ENVIRONMENTAL ISSUES}

since the global environment is a new area for Japan's foreign policy, Japan has not developed its own policy but rather follows the policy of the United Nations. Japan believes that to effectively deal with global environmental problems, it is important for Japan to play an active role. Japan also believes that the problem should be solved through concerted efforts of the international community, while trying to ensure "sustainable development," a concept predicted on achieving harmony between the environment and the economy, while giving due consideration to the conditions and needs of developing countries. ${ }^{78}$

In Diplomatic Bluebook 1989, environmental and other global problems were, for the first time, pointed out as one of the pillars of the International cooperation Initiative. problems, such as the destruction of the ozone layer, global warming, and the destruction of tropical forests, have become serious concerns of the international community. Although not new problems, those issues, for the first time, became an official priority of Japan's foreign policy in 1989. The

77

Ibid.

78

Ministry of Foreign Affairs, Japan. 1990. 99. 
Ministry of Foreign Affairs expressed its view about those problems;

...environmental problems have now assumed proportions that can only be dealt with on a global scale. Yet, it is necessary to pay special attention to the situations of the developing countries involving, for example, their complex national sentiments over the necessity of economic development and the environmental problem, as well as their population problem. The developed countries should help the developing countries effectively deal with the environmental problem, and international cooperation in financial and technical aspects must be promoted to give support to the developing countries endeavoring to protest the environment on their own. ${ }^{79}$

The movement started as a result of Prime Minister Takeshita's "Save The Earth" initiative. He placed high priority on environmental issues, and identified them as an area that Japan can lead the world. The initiative includes financial assistance to preservation projects, promotion of technology to develop environmentally conscious products, and Japan's leadership in international forums.

In May 1989, a "Ministerial Conference on Global Environmental Protection" was set up with the aim of coping with the problem of global environmental protection by the concerted efforts of the various ministries and agencies of the governments. During the conference, Japan's basic policy on global environmental protection was set forth. Japan offered at the Arch summit of the seven industrialized 
democracies in July 1989, to increase its aggregate sum of bilateral and multilateral assistance to about $\$ 3$ billion over the next three years for environmental efforts on the part of the developing countries. ${ }^{80}$ The Japanese government defined its policy of extending cooperation particularly in (1) the study and the preservation of forests, principally of tropical forests, (2) in proving the capabilities of the developing countries to deal with environmental problems.

Japan has been making positive contributions to the preservation of the global environment through aid to the UNEP and the International Tropical Timber organization (ITTO), and other international organizations involved in environmental issues. At the 8th ITTO Board meeting in May 1990, Japan announced a capital contribution of $\$ 20,130,0000^{81}$

Japan is gradually expressing its basic policy on these issues.

In order to actively tackle global environmental problems, Japan should reform its socioeconomic activities, thereby becoming more gentle to the earth. At the same time, it is necessary for Japan to take active part in the activities of international organizations especially in the United Nations, as well as in efforts to build an international framework on global environmental conservation through international instruments such as the U.N. Framework Convention on climate Change. It is also necessary for Japan to support environmental conservation measures of the

80

Ibid., 116.

81

Ministry of Foreign Affairs, Japan, 1990, 99-100. 
developing countries. ${ }^{82}$

Japan has not only been active in offering financial and technical assistance, but provided support to the holding of international conferences on the global environment.

At the London Summit of 1991, Japan announced efforts to expand its environment-related assistance by strengthening cooperation, making use of its experiences as an industrialized country, embarking on joint efforts with developing countries and offering cooperation in line with the stage of economic development in these countries. ${ }^{83}$

\section{CONCLUSION}

Official statements by the Government of Japan reviewed in this chapter expressed a set of guidelines in broad and general terms. These statements sound idealistic and there was no clear foreign policy emerges from national interests. On any issues, the Japanese government emphasized "cooperation with everybody." It has taken a dual stand as a member of the Western camp and of the Asian community. Yet, it is impossible to keep such an ambivalent stance simultaneously unless both the western countries and Asian community share their interests, which does not happen in most cases. It can be said that Japan's emphasis on good relations with other states prevented Japan from taking a

\footnotetext{
82 Ministry of Foreign Affairs, Japan, 1992, 121.

83 Ministry of Foreign Affairs, Japan, 1991, 151-152.
} 
clear policy on any issue.

As for human rights, Japan had been reluctant to place this issue on its foreign policy agenda. (I will address the reasons for this in chapter IV.) However, the recent politicization of human rights issues, with its connection to others on the international agenda such as ethnic conflicts, promotion of democracy, and arms proliferation have forced the Japanese government to take a stand. The government has applied a general western view as its fundamental stance, which respects the human rights as universal principle.

The Japanese government failed to place global environmental problems on its foreign policy agenda until recent years. Japan has started to respond to international moves concerning environmental issues, including several U.N.-sponsored conferences, and to express serious concerns about some issues. As its basic stance, the government followed the idea of sustainable development, which was the policy announced by the United Nations.

The Japanese government seems to lack a clear Middle East policy. It again applied U.N. resolutions as its basic stance. Because oil is a crucial factor of Japan's economy, its policies towards the oil-producing states of the region have made it difficult to take a position on the Middle East peace problem.

On issue of disarmament, the Japanese government clearly expressed its domestic and international pro-disarmament 
position in official statements. As for economic development, it seems that the concerns of the government are only in increasing and improving ODA. Behind the idealism of Japan's foreign aid may lie concrete national interests that aim at the possibility of future economic markets and compensation for the wartime legacy.

Overall, without a clear foreign policy, the Japanese government has used financial aid as diplomatic tool. The government emphasized financial and technical assistance without taking a political stance. For these sensitive issues, foreign aid could be used as excuses to avoid making clear foreign policy. Instead, Japan emphasizes cooperation with other countries in the existing international framework, including the United Nations. 
CHAPTER III

JAPAN'S VOTING BEHAVIOR FROM 1988 TO 1992

This chapter examines Japan's voting pattern in the United Nations General Assembly as an indicator of its foreign policy behavior. It employs factor analysis, which allows us to study group cohesion and the direction of dissent, and to consider Japan's positions on issues dealt with by the un General Assembly.

THE GENERAL ASSEMBLY BETWEEN 1988 AND 1992

In 1988, the Forty-Third Session of UNGA was devoted to major international security issues. Among them were the United States and the Soviet arms reductions and regional conflicts such as the Iran-Iraq war, Afghanistan, the Western Sahara, Southern Africa, Cambodia, and Cyprus. In addition to these political issues, global climate change and environmental damage, and poverty and debt in developing countries, were important item on the agenda.

In 1989, the world witnessed a sign of the end of the cold war with the collapse of communism in Eastern Europe led by the Soviet Union. Thus the Forty-Fourth Session was held at a turning point of history. This event affected several issues in the General Assembly. For example, consensus was 
achieved between the United states and the soviet Union on maintaining international peace and security. On Middle East issues, the changing position of the USSR and its European allies challenged to Israeli credentials. However, human rights issues, regional conflicts, and problems of economic development in developing countries, were among the challenges faced by the global community.

The Forty-Fifth session in 1990 was the first in more than four decades in which Eastern European nations did not vote as $a$ bloc and the first in which the German nation was represented by one German state, after 45 years of division. 84 overall, there was an increasing trend towards discussing matters and acting on them in a cooperative, nonconfrontational way.

There was hardly anything new on the agenda of the Forty-Fifth session. In the General Assembly, nearly all items had been discussed before, except the issue of Iraq's aggression against and occupation of Kuwait. The Persian Gulf Crisis directed world attention to the importance of the United Nations as an instrument of international peacekeeping, and indirectly, to the indefinite postponement of the annual challenge to Israel's U.N. credentials. In addition to the situation in the Gulf, human rights, poverty and underdevelopment, and the environment were major concerns

\footnotetext{
84 "Assembly agrees on major human rights, developing issues," UN CHRONICLE, Vol.XXVIII, No.1, March 1991: 4-11.
} 
of the session.

In 1991, the Forty-sixth session commenced with the admission of seven new states -- the Democratic People's Republic of Korea, the Republic of Korea, the Federated states of Micronesia, the Marshall Islands, Estonia, Latvia, and Lithuania.

Changes in Eastern Europe affected the pattern of consensus. of 281 resolutions, 748 (207) were adopted by consensus and there was a sharp drop of the number of resolutions taken by vote (only 74 resolutions were adopted with a vote). Relaxation of tensions between the United States and the Soviet Union was reflected in the number of arms control-related resolutions. The number declined from 62 in 1989 to 39 in $1991 .^{85}$ It reflected economic issues, too. Emerging nations of Eastern Europe and the former soviet Union became new advocates of market economies. Regional conflicts, human rights, and environmental issues, however, continued as the main concerns.

In 1992, the Forty-Seventh session opened to high expectations by the member states that the U.N. had matured into an instrument capable of maintaining international peace and security. There was little difference regarding issues discussed during the Forty-Seventh Session with the previous

85 United states, Department of states, Bureau of International Organization Affairs, United States Participation in the United Nations, 1991 (washington, D.C.: The U.S. Government Printing Office, 1992) 4. 
one.

Of the five sessions, the issues of the Forty-Third and Forty-Fourth sessions still showed the characteristics of the cold war. Significant effects of the end of the cold war were observed beginning with the Forty-Fifth Session. Since 1990, the number of adopted resolutions taken without votes has increased remarkably. (TABLE II) The end of the cold war created a positive atmosphere of cooperation rather than confrontation in the General Assembly. The issues that required votes were very similar from the Forty-Fifth Session to the Forty-Seventh Session. It seemed reasonable to choose two years from each period for intensive analysis. I chose the Forty-Third Session in 1988 which still reflected cold war preoccupations, and the Forty-sixth session in 1991, where the issues clearly reflect the end of the cold war and the aftermath of the Gulf war.

TABLE II

THE NUMBER OF ADOPTED RESOLUTIONS BETWEEN 1988 AND 1992

\begin{tabular}{||c|c|c|}
\hline Session(year) & $\begin{array}{c}\text { * of adopted } \\
\text { resolutions }\end{array}$ & $\begin{array}{c}\text { *f consensus } \\
\text { (percentage*) }\end{array}$ \\
\hline $43 \operatorname{rd}(1988)$ & 324 & $187(58 \%)$ \\
\hline $44 \operatorname{th}(1989)$ & 331 & $215(65 \%)$ \\
\hline $45 \operatorname{th}(1990)$ & 332 & $248(74 \%)$ \\
\hline $46 \operatorname{th}(1991)$ & 281 & $207(74 \%)$ \\
\hline $47 \operatorname{th}(1992)$ & 272 & $200(74 \%)$ \\
\hline
\end{tabular}


FACTOR ANALYSIS OF VOTING RECORDS

\section{Methods of Factor Analysis}

Factor analysis is a statistical technique used to identify a relatively small number of factors that can be used to represent relationship among sets of many interrelated variables. Because one session contains a very large number of resolutions(variables), it is reasonable to apply factor analysis for a study of voting alignment.

Resolutions without a vote were excluded since such votes statistically inform us of few or no policy differences. For the Forty-Third Session, 137 resolutions, and for the Forty-sixth session, 71 resolutions were included. The voting records of 159 states in 1988,166 states in 1991 were concerned.

The first necessity in a factor analysis is to arrive at a method of assigning a number to each nation's vote so that its positions on implicit factors might be determined. ${ }^{86}$ General Assembly rules and practices permit five different expressions of opinion on proposals: voting in favor, voting against, abstaining, announcing nonparticipation in the vote, and absenting oneself from the meeting. The latter two are without a doubt considered as not voting. The treatment of abstention is much ambiguous. The provisional rules of the U.N. General Assembly did not specify its effect. The precise

86 Alker and Russett, 30. 
meaning of any abstention becomes clear only when an explanation of the vote is offered afterward. since abstention indicates at least the will of participation in the vote, I include an abstention, with an affirmative and a negative vote as an important casting, and exclude announcing nonparticipation in the vote and absenting oneself from the meeting.

There are several techniques for transforming "Yes," "Abstain," or "No" into ranks (ordinal measurement) or regular numbers with meaningful distances between them (an interval level of measurement). I decided to use the "standardized ranks" which Alker and Russett employed in their voting behavior analysis. The standardized ranks contain more useful information than the usual bloc voting method of assigning a +1 score for any Yes, a zero for any Abstain, and a -1 score for any No, no matter how extreme or moderate the vote is in its context. ${ }^{87}$ The standardized ranks are a more plausible approximation of the underlying position of the state.

A "No" vote gets the lowest rank, "Abstain" a higher rank, and "Yes" the highest rank. For example, on a vote with 20 "No," 30 "Abstain," and 100 "Yes," the rank assigned to the 20 countries in the negative would be their average 10.5 . similarly, abstentions would merit 35.5 ; and affirmative votes would receive a rank of 100.5 . Subtracting these ranks

87 Ibid., 31. 
from the standardizing results so that the new voting scores have a mean of zero and an average squared value of one, the "standardized ranks" that result (indicated by $Z^{\prime} s$ ) would be $\mathrm{Z}(\mathrm{NO})=-2.28, \mathrm{Z}($ Abstain $)=-1.40$, and $\mathrm{Z}$ (Yes $)=0.87$. Standardized ranks are calculated for each vote in the forty-third session (135) and the forty-sixth session (71), and each score is different from one another unless they have the same proportion of Yes: No:Abstain.

There are two ways of factor loading: unrotated and rotated factor analysis. The rotated factor pattern is supposed to provide simpler substantive factor interpretations but does not contradict the emphasis on frequent or pervasive voting alignments suggested by the unrotated factor pattern. ${ }^{88}$ Therefore, $I$ will use only rotated factors for the final analysis. Factor analysis provides useful information that indicates the group to which Japan belongs. The data was drawn from press releases by the U.N. Secretariat. ${ }^{89}$

Issues at the Forty-Third General Assembly

In the plenary, the wide variety of topics to be

88

Ibid. , 34-38.

89 United Nations, General Assembly-Department of Public Information, Document No: Press Release GA/7814, "Resolutions and Decisions Adopted by the General Assembly during its Forty-Third Session. From 20 September to 22 December 1988." Document No: Press Release GA/8307, "Resolutions and Decisions Adopted by the General Assembly during its FortySixth Session. From 17 September to 20 December 1991." 
addressed included such politically sensitive areas as the Middle East, Central America, Cambodia, Afghanistan, IranIraq, Cyprus, South Africa and the Western Sahara.

Issues in the First committee were related to halting the nuclear arms race, obtaining a nuclear test ban, preventing an arms race in outer space, Soviet-United States bilateral nuclear-arms negotiations, conventional disarmament and a chemical-weapons ban. The committee also reviewed extended studies, such as the climatic and global effects of nuclear war, and the economic and social consequences of the arms race and military expenditures.

The agenda items in the special political comittee dealt with Israeli practices affecting the human rights situation in the occupied territories, and the work of the United Nations Relief and Works Agency for Palestine Refugees in the Near East(UNRWA). A comprehensive review of the whole question of peace-keeping operations, in all their aspects, was also discussed.

The second committee reviewed issues related to development and international economic cooperation, including trade issues. The external debt crisis and developing countries was main issue before the committee.

The Third Committee's voluminous and varied agenda dealt with items related to social, humanitarian and human rights questions. Major concerns were drug control, racial discrimination, self-determination, mercenarism, women, 
refugees, and human rights. Specific human rights situations in Afghanistan, Chile, El Salvador, and Iran were examined. Conditions in dependent territories, including New Caledonia, the Trust Territory of the Pacific Islands and Western Sahara, were reviewed in the Forth Committee. Regular budgetary and personnel matters were dealt with in the Fifth Committee. The items of the sixth committee dealt with such matters as the new international economic order, peaceful settlement of disputes between states, and strengthening of the role of the organization.

After examining a record 152 agenda items, the Assembly adopted 324 resolutions on a wide range of political, economic, social and legal issues. Of these resolutions, 137 of the questions adopted with votes will be the variables of the analysis of voting during the Forty-Third session.

\section{Voting Dimensions in 1988}

How many voting dimensions underlie the voting records of the forty-third session? To help me decide how many factors (voting dimensions), it is helpful to examine the percentage of total variance explained by each. Eigen values (variance the factor contains) for the variables are shown in TABLE III. The eigen values describe that factor 1 accounts for 38.38 of the variance for this variable. Factor 2,3 , and 4 explain $9.98,4.87,4.78$ of the variance respectively. Almost $80 \%$ of the variance is explained by the first seventeen factors. Thus, a model with seventeen factors may 
be adequate to represent the data.

The rotated factor pattern (matrix) is displayed in Table IV. Factors above 0.60 have been printed in boldface type. The first four factors represent important groups of issues. The first component of Assembly voting will be interpreted "social and human rights issues." It consists of Palestinian issues, and the living conditions and situation in Cambodia, Namibia, South Africa. Also included are issues of global human rights which affected by environmental destruction and warfare. The second principal component may be simply labeled "Israeli-Palestinian conflicts" because each variable above 0.60 in this factor is related to Middle East peace problems, such as issues of palestinian refugees,

\section{TABLE III}

EIGEN VALUE AND PERCENTAGE OF VARIANCE, VOTING DIMENSIONS IN THE 43RD SESSION OF 1988

$\begin{array}{rrrr}\text { Factor } & \text { Eigenvalue } & \text { Pct of Var } & \text { Cum Pct } \\ 1 & 51.74287 & 38.3 & 38.3 \\ 2 & 13.38530 & 9.9 & 48.2 \\ 3 & 6.49502 & 4.8 & 53.1 \\ 4 & 6.33396 & 4.7 & 57.7 \\ 5 & 4.19665 & 3.1 & 60.9 \\ 6 & 3.06604 & 2.3 & 63.1 \\ 7 & 2.84491 & 2.1 & 65.2 \\ 8 & 2.55715 & 1.9 & 67.1 \\ 9 & 2.32343 & 1.7 & 68.8 \\ 10 & 2.27460 & 1.7 & 70.5 \\ 11 & 2.14585 & 1.6 & 72.1 \\ 12 & 1.87414 & 1.4 & 73.5 \\ 13 & 1.71744 & 1.3 & 74.8 \\ 14 & 1.64538 & 1.2 & 76.0 \\ 15 & 1.53295 & 1.1 & 77.1 \\ 16 & 1.35797 & 1.0 & 78.1 \\ 17 & 1.32907 & 1.0 & 79.1\end{array}$


TABLE IV

ROTATED FACTOR MATRIX, THE 43RD GENERAL ASSEMBLY

Variables

3 League of Arab states

11 Nicaragua:Judgement of

12 Organization of African

13 South Africa:Municipal

14 Mayotte Comorian Island

18 Law of Sea

19 Kampuchea situation

21 Palestine:uprising in West

22 Peace:right to

23 Atlantic, South:Zone of peace

25

26A

26B

26C

26D

$26 \mathrm{E}$

45

46

47

49

$50 \mathrm{~A}$

$50 B$

$50 \mathrm{C}$

50D

5OE

$50 \mathrm{~F}$

$50 \mathrm{H}$

$50 \mathrm{~J}$

$50 \mathrm{~K}$

$54 A$

$54 \mathrm{~B}$

$54 \mathrm{C}$

175A

175B

175C

176

177

$63 A$
Falkland Island:question

Namibia:situation in

Namibia:Security Council

Namibia:UN Work Programme

Namibia:dissemination of info

Namibia:UN Fund for

Decolonization

Decolonization:dissemination

Decade for the eradication of

GA:Geneva meetings, Palestine

South Africa:liberation

South Africa:military

South Africa:sanctions

South Africa:measures

South Africa:relation with

Apartheid:Special Committee

Apartheid:dissemination of

South Africa:oil embargo

Apartheid:elimination of

Middle East:situation in

Israel:measures against

Jerusalem:character and

Inalienable rights

Palestine: Secretariat activity

Palestine: Secretariat activity

International Peace Conference

Palestine:status in UN system

Nuclear weapons:Latin America
F1

F2

F3

F4

$\begin{array}{llll}.186 & .661 & .114 & .287\end{array}$

$.177 \quad .125 \quad .077-.001$

$\begin{array}{llll}.111 & .125 \quad .003 \quad .640\end{array}$

$\begin{array}{llll}.127 & .053 \quad .044 \quad .381\end{array}$

$.598 \quad .041 \quad .126-.003$

$\begin{array}{llll}.169 & .117 \quad .084 \quad .121\end{array}$

$\begin{array}{llll}-.163 & -.041 \quad .055 \quad .022\end{array}$

$.112 .135-.080-.076$

$\begin{array}{llll}.712 & .079 & .113 \quad .102\end{array}$

$\begin{array}{llll}.398 & .062 \quad .532 \quad .282\end{array}$

$.201 \quad .058 \quad .048-.185$

$\begin{array}{llll}.822 & .075 & .060 \quad .025\end{array}$

$\begin{array}{llll}.496 & .191 & .450 \quad .047\end{array}$

$\begin{array}{llll}.352 & .082 & .322 & .198\end{array}$

$\begin{array}{llll}.777 & .109 & .175 & .044\end{array}$

$\begin{array}{llll}.312 & .110 & .238 & .222\end{array}$

$\begin{array}{llll}.386 & .225 & .360 & .003\end{array}$

$\begin{array}{llll}.317 & .281 & .297 & .006\end{array}$

$\begin{array}{llll}.850 \quad .078 & .204-.040\end{array}$

$\begin{array}{llll}.195 & .618 \quad .153 \quad .154\end{array}$

$\begin{array}{llll}.855 & .114 & .121 & .108\end{array}$

$\begin{array}{llll}.743 & .126 & .166 \quad .060\end{array}$

$\begin{array}{llll}.726 & .062 \quad .093 \quad .081\end{array}$

$\begin{array}{llll}.547 & .097 & .233 & .081\end{array}$

$.674 .109 \quad .048 \quad .012$

$\begin{array}{llll}.439 & .239 & .522 \quad .063\end{array}$

$.810 \quad .119 \quad .135 \quad .095$

$.420 \quad .117 \quad .254 \quad .262$

$.242 \quad .117 \quad .254 \quad .262$

$.522 \quad .335 \quad .148-.025$

$.466 \quad .291 \quad .117-.052$

$\begin{array}{llll}.045 & .620 \quad .112 \quad .034\end{array}$

$\begin{array}{llll}.623 & .135 & .155 & .088\end{array}$

$\begin{array}{llll}.623 & .135 & .155 & .088\end{array}$

$\begin{array}{llll}.556 \quad .134 & .247 \quad .122\end{array}$

$\begin{array}{llll}.186 & .389 & .082 \quad .195\end{array}$

$\begin{array}{llll}.551 & .173 \quad .069 \quad .100\end{array}$

$\begin{array}{llll}.558 & .196 \quad .566 \quad .069\end{array}$ 
TABLE IV

ROTATED FACTOR MATRIX, THE 43RD GENERAL ASSEMBLY (continued)

Variables

63B Nuclear weapons:testing

64 Nuclear weapons:testing

66 Nuclear weapons:testing

68 Nuclear weapons:Asia

69 Nuclear weapons:non-use

70 Space, outer:prevention of

$71 \mathrm{~A}$ Nuclear weapons:Africa

71B South Africa: nuclear

72 Weapons:mass destruction

75A Nuclear weapons:negotiations

75G Military matters:study on

75H Disarmament

75 I Disarmament

75J Nuclear weapons:facilities

75K Nuclear weapons:fissionable

75L Weapons:naval, study on

75N Weapons: Sea-Bed Treaty

750 Nuclear weapons: IMF Treaty

750 Waste dumping:prohibition of

$75 S$ Disarmament:regional

75T Waste dumping:radioactive

76A Disarmament:international

76B Nuclear weapons:freeze

76C World disarmament

76E Weapons:non-use

77A Security:international

77B Disarmament:GA

78B Nuclear weapons:non-use

78C Disarmament:international

78D Nuclear war:climatic effects

78E Nuclear weapons:arms race

$78 \mathrm{~F}$ Nuclear war: prevention of

$78 \mathrm{I}$ Conference of disarmament

$78 \mathrm{~J}$ Nuclear weapons:economic

88 International security

$78 \mathrm{M}$ Conference of disarmament

80 Israel:nuclear armament $\begin{array}{llll}\text { F1 } & \text { F2 } & \text { F3 } & \text { F4 }\end{array}$

$\begin{array}{llll}.784 & .164 \quad .299 \quad .092\end{array}$

$\begin{array}{llll}.180 & .417 \quad .312 \quad .102\end{array}$

$\begin{array}{llll}.144 & .032 & .0307 & .056\end{array}$

$\begin{array}{llll}.726 & .110 \quad .303 \quad .056\end{array}$

$\begin{array}{llll}.062 & .366 \quad .246 \quad .522\end{array}$

$\begin{array}{llll}.093 & .474 \quad .269 & .702\end{array}$

$.240 \quad .546 \quad .365 \quad .131$

$.515 \quad .274 \quad .564 \quad .129$

$\begin{array}{llll}.182 & .766 \quad .242 \quad .230\end{array}$

$\begin{array}{llll}.503 & .254 \quad .725 \quad .020\end{array}$

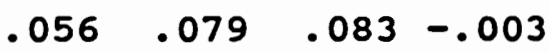

$\begin{array}{llll}.793 & .218 \quad .308 \quad .070\end{array}$

$\begin{array}{llll}-.045 \quad .155 & .162 \quad .086\end{array}$

$\begin{array}{llll}.634 & .193 \quad .239 & .056\end{array}$

$\begin{array}{llll}.194 & .151 & .411 & .232\end{array}$

$\begin{array}{llll}.172 & .761 & .314 & .242\end{array}$

$\begin{array}{llll}.420 & .232 & .726 \quad .034\end{array}$

$\begin{array}{llll}-.060 \quad .031 & .136 \quad .036\end{array}$

$.061 .061 \quad .163-.014$

$\begin{array}{llll}.069 & .270 \quad .122 \quad .093\end{array}$

$\begin{array}{llll}.520 & .237 & .720 & .069\end{array}$

$\begin{array}{llll}.755 & .172 & .301 & .069\end{array}$

$\begin{array}{llll}.471 & .205 & .569 & .039\end{array}$

$\begin{array}{llll}.428 & .085 & .762 \quad .150\end{array}$

$.749 \quad .158 \quad .519 \quad .086$

$.649 \quad .180 \quad .505 \quad .051$

$\begin{array}{llll}.160 & .297 \quad .380 \quad .401\end{array}$

$\begin{array}{llll}.719 & .133 & .460 \quad .059\end{array}$

$\begin{array}{llll}.517 \quad .213 & .626 \quad .025\end{array}$

$\begin{array}{llll}.388 & .102 & .755 & .165\end{array}$

$.630 \quad .164 \quad .632 \quad .081$

$.617 \quad .182 \quad .641 \quad .081$

$\begin{array}{llll}-.087 & -.001 \quad .160 \quad .067\end{array}$

$\begin{array}{llll}.407 \quad .276 & .739 \quad .046\end{array}$

$\begin{array}{llll}.808 & .158 \quad .301 & .150\end{array}$

$\begin{array}{llll}.616 & .183 & .641 & .081\end{array}$

$\begin{array}{llll}.395 & .245 & .337 \quad .023\end{array}$ 
TABLE IV

ROTATED FACTOR MATRIX, THE 43RD GENERAL ASSEMBLY (continued)

Variables

81B Weapons:verification UN role

82 Nuclear weapons

83A Antarctica:minerals of

83B Antarctica: South African

86 Political dialogue

87 Declaration:Life in Peace

89 International security

57A Palestine:refugees

57D Palestine:scholarship

57E Palestine:refugees

57F Palestine:ration distribution

57G Palestine:return to

57H Palestine:properties

57 Palestine:protection of

57J Palestine:University of

58A Israeli-occupied territories

58B Israeli-occupied territories

58C Israeli-occupied territories

58D Israeli-occupied territories

58E Israeli-occupied territories

58F Golan, Syrian Arab: Israeli

58G Israeli-occupied territories

60A Information Committee

60B UN Educational,scientific, and

178 Palestine:Assistance to people

182 Development:strategy

185 Nicaragua:trade embargo

187 Money and finance

195 Developing countries:poverty

197

198

209

92

97

106

107

110
F1

F2

F3

F4

\begin{tabular}{rrrr}
.110 & .399 & .325 & .610 \\
.048 & .257 & .154 & -.069 \\
.090 & .024 & .146 & .008 \\
\hline .186 & .112 & .119 & .054 \\
.828 & .160 & .345 & .124 \\
.843 & .149 & .336 & .097 \\
.352 & .142 & .400 & .016 \\
.186 & .821 & .077 & -.351 \\
.145 & .848 & .091 & -.343 \\
.154 & .914 & .129 & .199 \\
.755 & .319 & .275 & .055 \\
.642 & .415 & .159 & .017 \\
.625 & .360 & .187 & .028 \\
.108 & .847 & .123 & .126 \\
.154 & .914 & .129 & .199 \\
.500 & .370 & .048 & -.012 \\
.086 & .808 & .045 & .106 \\
.057 & .855 & .105 & .134 \\
.164 & .860 & .123 & .190 \\
.095 & .868 & .026 & .135 \\
.096 & .883 & .050 & .124 \\
.094 & .765 & .129 & .087 \\
.751 & .323 & .221 & .026 \\
.566 & .400 & .230 & .054 \\
.672 & .073 & .088 & .248 \\
.125 & .347 & .048 & .847 \\
.211 & .106 & .177 & .247 \\
.789 & .087 & .123 & .280 \\
.719 & -.172 & .085 & .453 \\
.098 & .154 & .034 & .892 \\
.167 & .061 & .063 & .811 \\
.070 & .180 & .067 & .893 \\
.834 & .054 & .266 & .025 \\
.020 & .033 & .065 \\
.051 & .010 & .025 \\
.076 & .083 & .031
\end{tabular}


TABLE IV

ROTATED FACTOR MATRIX, THE 43RD GENERAL ASSEMBLY (continued)

Variables

113 Human rights:indivisibility

124

125

126

137

146

156

158

28

29

30

33

222B

228

229

48

$160 \mathrm{~A}$

$160 \mathrm{~B}$

162

163

164

$171 \mathrm{~A}$

$171 B$

Human rights: property

Human rights: UN system role

Human rights:un system role

Iran:human rights situation

Human rights:of migrant

Social life, improvement of

Chile:human rights situation

Non-self governing territory

Decolonization

Decolonization

Western Sahara question

Committee on conference

UN disarmament observer force

UN interim force in Lebanon

PLO:Visa request

PLO: documentation

Observers

New International Economic

Disputes, peaceful settlement

peace and security

Good-neighbour lines

Good-neighbour lines $\begin{array}{llll}\text { F1 } & \text { F2 } & \text { F3 } & \text { F4 }\end{array}$

$\begin{array}{llll}.834 & .090 & .151 & .031\end{array}$

$\begin{array}{llll}.876 & .066 \quad .056 \quad .013\end{array}$

$.861 \quad .082 \quad .142 \quad .055$

$.900-.015 \quad .137-.155$

$-.029-.011-.109 \quad .005$

$\begin{array}{llll}.187 & .128 & .218 & .302\end{array}$

$\begin{array}{llll}.845 & .067 & .132 & .020\end{array}$

$\begin{array}{llll}-.136 \quad .120 & -.029 \quad .098\end{array}$

$\begin{array}{llll}.098 & .201 & .046 \quad .377\end{array}$

$\begin{array}{llll}.798 & .023 \quad .107-.010\end{array}$

$\begin{array}{llll}.735 & .001 \quad .011-.009\end{array}$

$\begin{array}{llll}.197 & -.061 & .014 & .002\end{array}$

$\begin{array}{llll}.576 & .244 & .349 & .032\end{array}$

$\begin{array}{llll}.045 & .111 & .014 & .049\end{array}$

$\begin{array}{llll}.063 & .118 \quad .062 \quad .043\end{array}$

$\begin{array}{llll}.211 & .467 & .069 & .205\end{array}$

$\begin{array}{llll}.624 & .039 & .014 \quad .029\end{array}$

$\begin{array}{llll}.655 & .030 \quad .102 \quad .050\end{array}$

$\begin{array}{llll}.812 & .046 \quad .131 & .053\end{array}$

$\begin{array}{llll}.645 & .015 & .253 \quad .015\end{array}$

$\begin{array}{llll}.678 & .102 & .313 & .049\end{array}$

$-.108 \quad .001-.090-.028$

$\begin{array}{llll}.655 & -.001 & .097 \quad .012\end{array}$

and of Israeli-occupied territories. The third voting component contains "arms control and disarmament issues." The fourth factor contains issues related to "problems in developing countries." The questions of cooperation between the Organization of African Unity and the U.N., international cooperation for eradication of poverty in developing countries, preparations for an international development strategy, fulfillment of the target for ODA, durable 
solutions to debt problems, and special assistance to frontline states are all included under the fourth factor. Those four components fully comprise the major issues before the Forty-Third Session in 1988.

To gauge Japan's voting positions on each issue, I used a technique called 'plot by country.'(Figure 2, 3, 4) Figure 2 shows the plot "social and human rights issues" versus "Israeli-Palestinian conflicts." The plot represents two main groups, a Western industrial bloc and a developing countries' bloc. The United States and Israel isolated themselves from any blocs. Japan belongs to the Western industrial bloc in this plot, which took an anti-Israel position. Japan tended to affirm the resolutions concerning Middle East peace problems. It tended to abstain from questions of social and human rights on those issues that the United States constantly voted against.

In Figure 3, rotated factor scores on "social and human rights issues" and "arms control and disarmament issues" shows three separate blocs, developing countries, the Group of Seven (G-7, the United States, Great Britain, Canada, West Germany, France, Italy, and Japan) bloc, and North-European countries and Australia bloc. Although the map shows that Japan kept a neutral position on issues of arms control and disarmament, it does not mean that Japan affirmed all questions related to disarmament issues (Japan actually abstained from half of those resolutions). 
Figure 2. Factor scores on "social and human rights issues" (vertical) and "Israeli-Palestinian conflicts" (Horizon) at the $43 \mathrm{rd}$ General Assembly

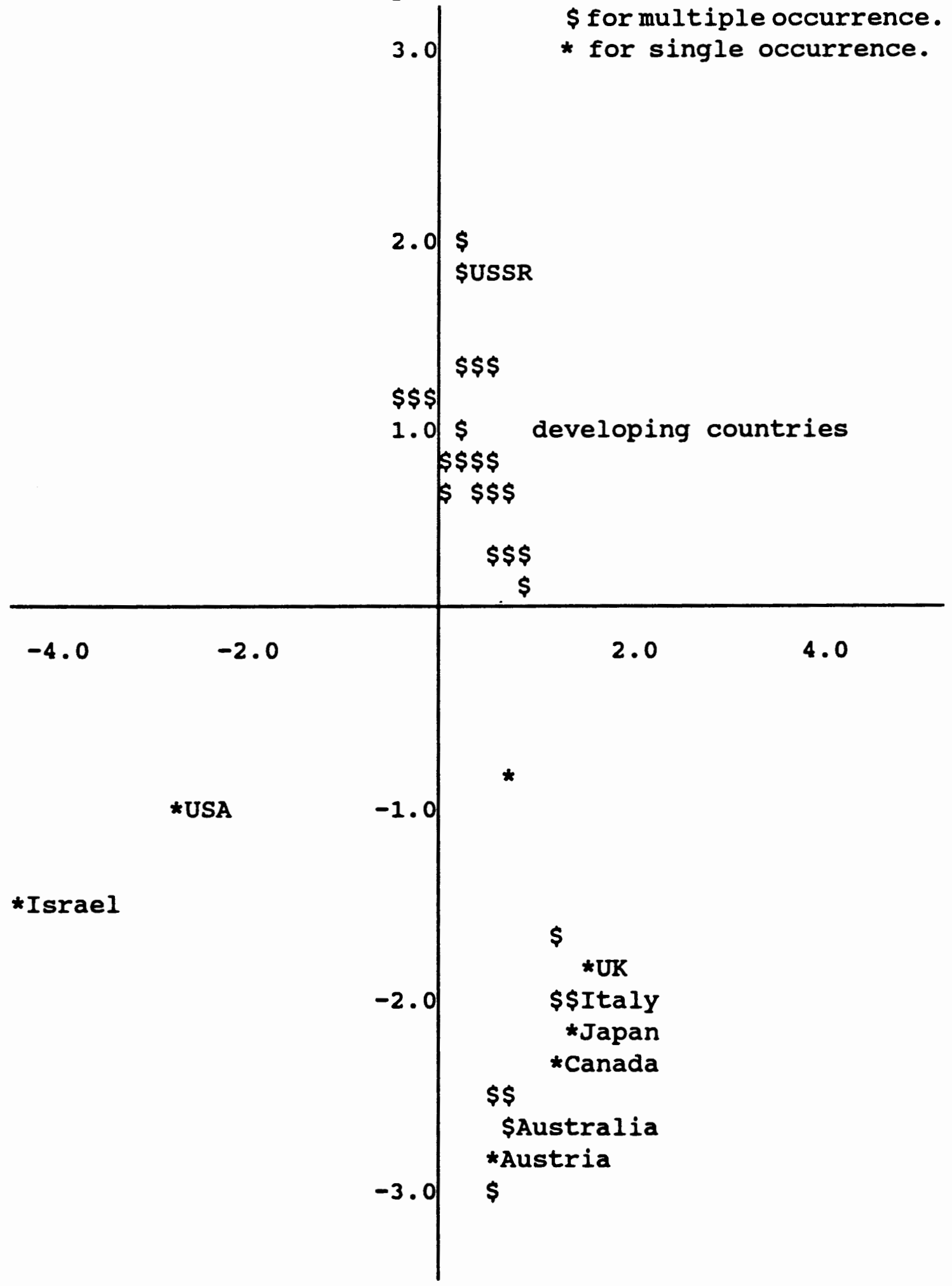


Figure 3. Factor scores on "social and human rights issues" (vertical) and "arms reduction" (horizon) at the 43 rd General Assembly

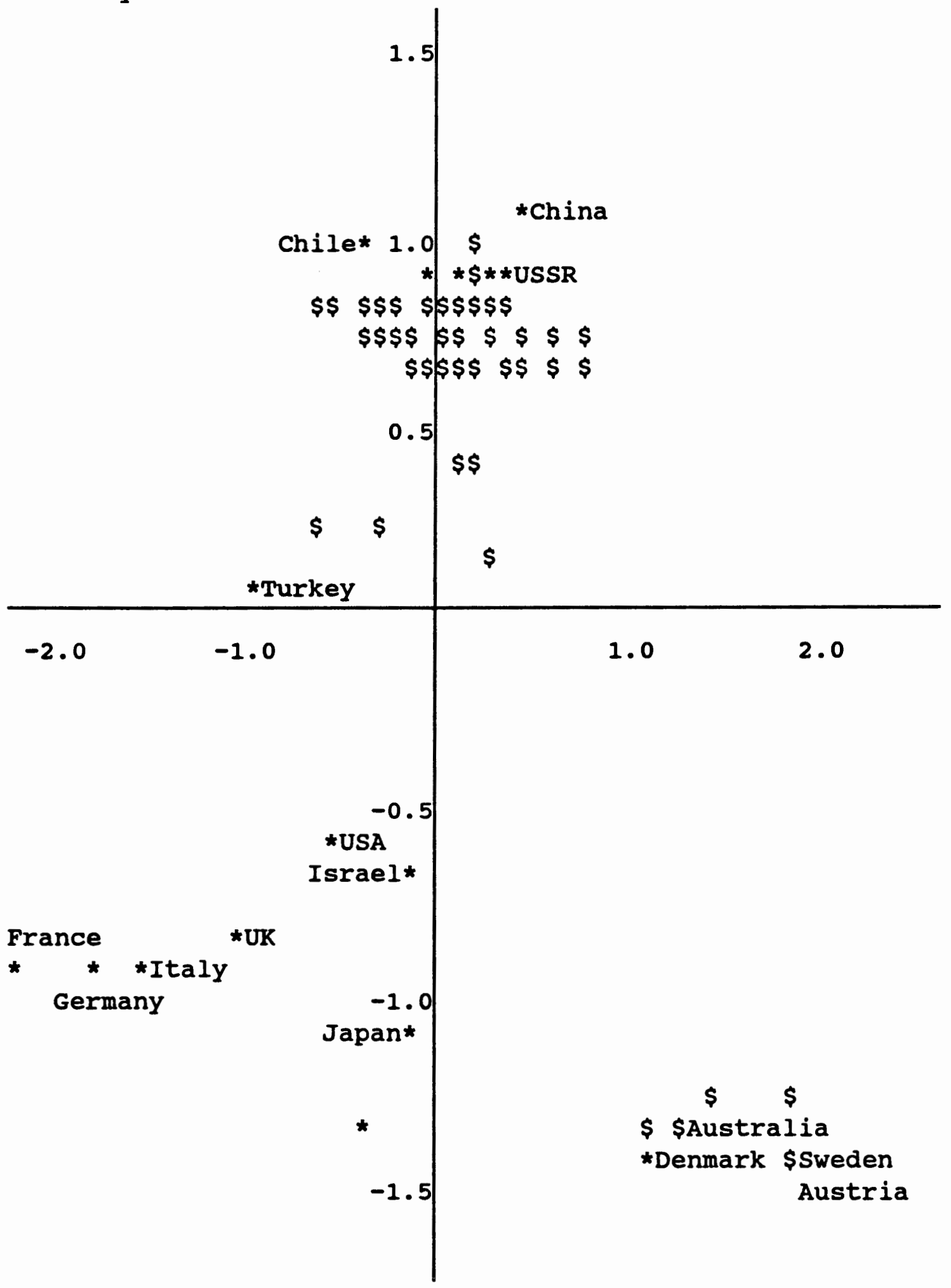


Figure 4. Factor scores on "arms reduction" (vertical) and "issues of developing countries" (horizon) at the 43rd General Assembly

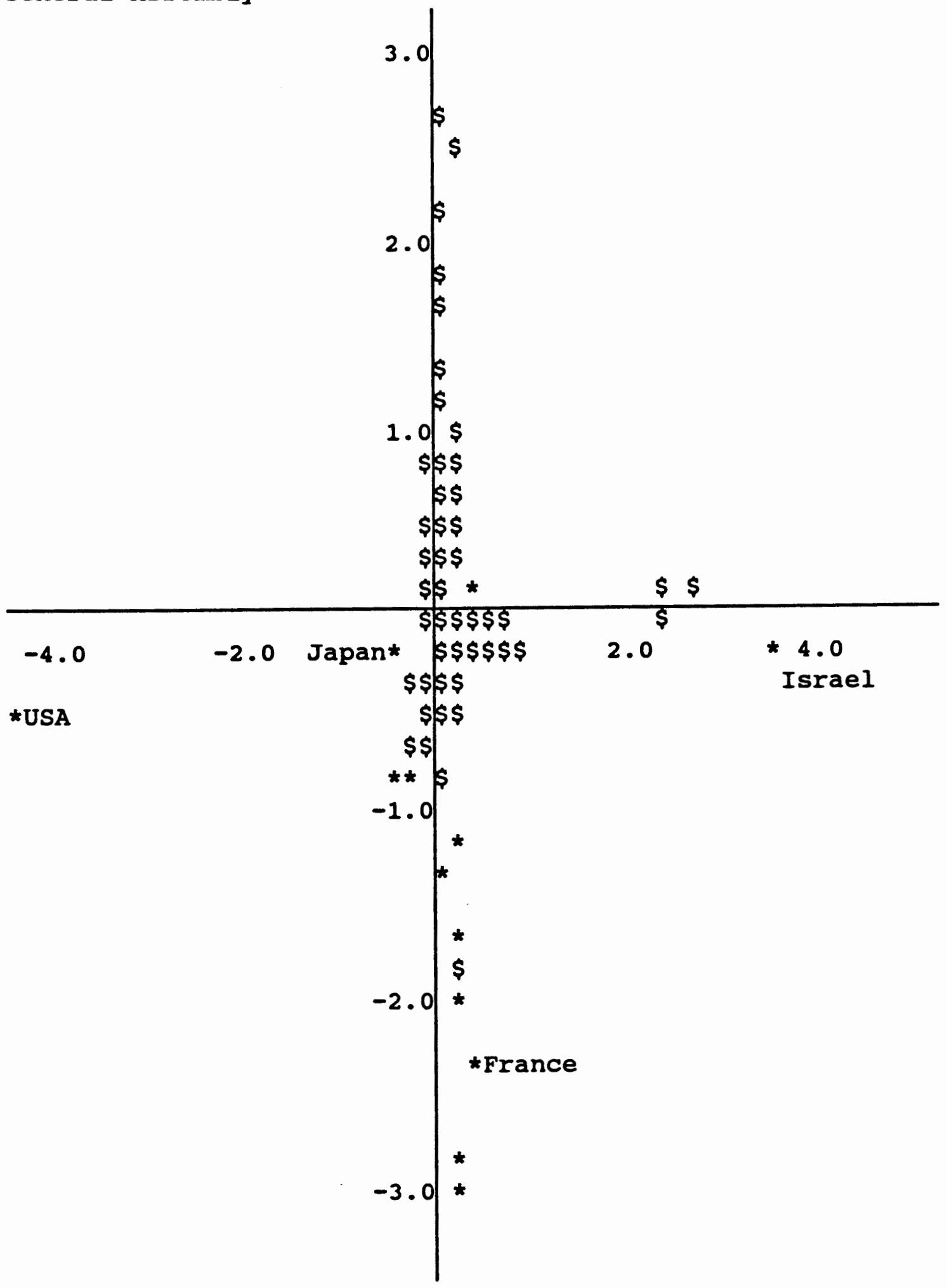


Finally, Figure 4, the plot "issues of arms reduction" on "issues of developing countries," reveals the United States and Israel isolated on the in opposite sides on the issues from developing countries. Other countries, including Japan, took pro-Arab/anti-Israel positions on those issues. Japan's stance regarding issues of developing countries was very supportive of those nations. It almost always voted affirmatively on those resolutions, abstaining only from the proposal for a durable solution of debt crisis.

To sum up the voting alignment of 1988, while Japan did not isolate itself from the industrial bloc, there was no indication that Japan took the position of Asian countries. Japan's voting pattern was very similar to that of the G-7 countries, except the United States. Japan voted neutrally or positively on "Israeli-Palestinian conflicts." It took an anti-Israel position while the United States took a proIsrael stance. Japan's voting behavior on "arms control and disarmament issues," indicates a less negative reaction, yet not a strong pro-disarmament position, either. On "issues of developing countries," it took a slightly negative position that indicates occasional abstentions from resolutions. It tended to abstain or vote against the protection of "social and human rights."

\section{Issues at the Forty-Sixth General Assembly}

The Forty-sixth General Assembly was opened in a changed international climate that would help accelerate solutions to 
ongoing crises on the world body's agenda. Changes in Soviet Union and Eastern Europe positively affected long-standing voting blocs, which had built up during the cold war. In the plenary sessions, intensive discussions took place on reforming the work and structure of the United Nations, in addition to the old stubborn problems such as regional conflicts and South Africa's apartheid policies. ${ }^{90}$

In the First committee, discussion was focused on weapons of mass destruction. Nineteen disarmament items were considered, as well as two international security questions, and one item on the question of Antarctica.

Main concerns in the Special committee were protection and security of small states, and Israeli practices that affected the human rights of the population of the occupied territories, and the work of UNRWA. Other agenda items in the Special Committee included: effects of atomic radiation, international cooperation in the peaceful uses of outer space, comprehensive review of the whole question of peacekeeping operations, and information issues.

Items in the second committee focused on economic and humanitarian assistance or reconstruction. The external debt crisis was of crucial concern. The protection of the global climate for present and future generations was another important item.

90 "Reform Proposals Circulate During 46th Assembly," UN CHRONICLE, Vol.XXIX, No.1, March 1992: 9-11. 
Items before the Third committee included Iraqi human rights violations in kuwait. Other human rights issues, such as the rights of the population of the occupied territories, the human rights situations in Iraq and South Africa were main items.

The Fourth Committee focused on the remaining 18 NonSelf-Governing Territories, located predominantly in the Caribbean and Pacific subregions. Almost all budgetary and legal issues were adopted by consensus.

\section{Voting Dimensions in 1991}

First, eigen values were examined to look at important factors. TABLE V shows that almost $80 \%$ of the total variance is attributable to the first thirteen factors. A model with thirteen factors may be adequate to represent the data.

The rotated factor pattern (matrix) is displayed in TABLE VI. The first component will be labeled "humanitarian and other global issues," which includes, such items as living conditions in the Middle East and South Africa, the International Convention on Suppression and Punishment, selfdetermination, decolonization, and improvement of human rights, as well as international disarmament issues as they effect human rights. The second factor contains the resolutions about "Israeli-occupied territories," and the third factor is limited to the issues of "Palestinian refugees." The fourth component contains issues of "arms control and disarmament issues," especially those concerning 


\section{TABLE V}

EIGEN VALUES AND PERCENTAGE OF VARIANCE, VOTING DIMENSIONS IN THE 46TH SESSION OF 1991

$\begin{array}{rrrr}\text { Factor } & \text { Eigenvalue } & \text { Pct of var } & \text { Cum Pct } \\ 1 & 23.71822 & 33.4 & \\ 2 & 8.06634 & 11.4 & 33.4 \\ 3 & 3.86168 & 5.4 & 44.8 \\ 4 & 3.18761 & 4.5 & 50.2 \\ 5 & 2.89973 & 4.1 & 54.7 \\ 6 & 2.45520 & 3.5 & 58.8 \\ 7 & 2.02407 & 2.9 & 62.2 \\ 8 & 1.89494 & 2.7 & 65.1 \\ 9 & 1.62463 & 2.3 & 67.8 \\ 10 & 1.42799 & 2.0 & 70.0 \\ 11 & 1.29222 & 1.8 & 72.1 \\ 12 & 1.27381 & 1.8 & 73.9 \\ 13 & 1.10410 & 1.6 & 75.7 \\ & & & 77.2\end{array}$

TABLE VI

ROTATED FACTOR MATRIX, THE 46TH GENERAL ASSEMBLY

Variables

9 Mayotte, Comorian Island of

10 Cultural property, return or

16 International atomic energy

19 Atlantic, South:zone of peace

24 League of Arab States:coop

71 Decolonization

72 Decolonization

74A Committee the on inalienable

74B Palestine: Secretariats

74C Palestine:Secretariats

75 Middle East:International

76 Intifadah:Israeli-occupied

78 Law of sea

79B Apartheid:Special Committee

79C South Africa:military

79D South Africa:relation with $\begin{array}{llll}\text { F1 } & \text { F2 } & \text { F3 } & \text { F4 }\end{array}$

$\begin{array}{rrrr}.624 & .189 & -.012 & .077 \\ .528 & .063 & .027 & -.028 \\ .002 & .087 & .098 & .114 \\ .061 & .024 & .050 & .289 \\ .123 & .298 & .232 & .169 \\ .567 & .048 & .173 & .122 \\ .588 & -.042 & .256 & .147 \\ .490 & .160 & .189 & .080 \\ .457 & .169 & .185 & .090 \\ .453 & .148 & .200 & .088 \\ .428 & .282 & .160 & .016 \\ .012 & .420 & .150 & .084 \\ .116 & .187 & .394 & .264 \\ .359 & .079 & .176 & .103 \\ .555 & .069 & .043 & .019 \\ .552 & .110 & .059 & .019\end{array}$


TABLE VI

ROTATED FACTOR MATRIX, THE 46TH GENERAL ASSEMBLY (continued)

Variables

79E South Africa:oil embargo

82A Middle East:situation in

82B Jerusalem:character and

86 Racial discrimination

28 Nuclear weapons:testing

29 Nuclear weapons: testing

31 Nuclear weapons:Asia

32 Nuclear weapons:non-use

33 Nuclear weapons:arms races

34A South Africa: nuclear

36D Nuclear weapons: fissionable

$36 \mathrm{I}$ Disarmament:regional

$36 \mathrm{~J}$ Nuclear weapons:negotiations

36L Waste dumping:radioactive

37C Nuclear weapons: freeze

37D Nuclear weapons:non-use

37F Disarmament: Africa, Asia, Latin

38B Disarmament: comprehensive

$38 \mathrm{C}$ Conference on disarmament

39 Israel:nuclear armament

46A Palestine:assistance to people

46D Palestine:scholarship

46E Palestine:refugees

$46 \mathrm{~F}$ Palestine:refugees, ration

46G Palestine:refugees, return

46H Palestine:refugees, property

$46 \mathrm{I}$ Palestine:refugees, protect

$46 \mathrm{~J}$ Jerusalem:University of

46K Palestine:refugees, students

47A Israeli-occupied territories

47B Israeli-occupied territories

47C Israeli-occupied territories

47D Israeli-occupied territories

47E Israeli-occupied territories

47F Israeli-occupied territories

47G Israeli-occupied territories

162 $\begin{array}{llll}\text { F1 } & \text { F2 } & \text { F3 } & \text { F4 }\end{array}$

$\begin{array}{llll}.492 & .046 & .134 & .025\end{array}$

$\begin{array}{llll}.672 & .060 & .052 & -.027\end{array}$

$\begin{array}{llll}.075 & .372 & .125 & .117\end{array}$

$-.037 \quad .022-.060-.001$

$\begin{array}{llll}.673 & -.005 & .217 & .310\end{array}$

$\begin{array}{llll}.173 & .156 & .224 & .732\end{array}$

$\begin{array}{llll}.208 & -.034 & .166 & .533\end{array}$

$\begin{array}{llll}.185 & .122 & .134 & .846\end{array}$

$\begin{array}{llll}.134 & .256 & .195 & .762\end{array}$

$\begin{array}{llll}.738 & .189 & .156 & .360\end{array}$

$\begin{array}{llll}.144 & .117 & .072 & .815\end{array}$

$\begin{array}{llll}.109 & .106 & .093 & .738\end{array}$

$\begin{array}{llll}.607 & .022 & .153 & .247\end{array}$

$\begin{array}{llll}.016 & .004 & .023 & .100\end{array}$

$\begin{array}{llll}.821 & .151 & .150 & .296\end{array}$

$\begin{array}{llll}.896 & -.015 & .123 & .079\end{array}$

$\begin{array}{llll}.164 & .144 & .088 & .360\end{array}$

$\begin{array}{llll}.826 & .141 & .104 & .269\end{array}$

$\begin{array}{llll}.832 & -.019 & .121 & .234\end{array}$

$\begin{array}{llll}.560 & .064 & -.020 \quad .115\end{array}$

$.143 \quad .191 \quad .739-.016$

$\begin{array}{llll}.109 & .248 & .839 & .034\end{array}$

$\begin{array}{llll}.109 & .324 & .784 & .264\end{array}$

$\begin{array}{llll}.633 & .040 & .644 & .139\end{array}$

$\begin{array}{llll}.600 & .105 & .674 & .140\end{array}$

$\begin{array}{llll}.608 & .103 & .670 & .138\end{array}$

$\begin{array}{llll}.085 & .439 & .793 & .157\end{array}$

$\begin{array}{llll}.092 & .440 & .778 & .149\end{array}$

$\begin{array}{llll}.095 & .405 & .722 & .261\end{array}$

$\begin{array}{llll}.582 & .387 & .276 & .053\end{array}$

$\begin{array}{llll}.102 & .899 & .181 & .140\end{array}$

$\begin{array}{llll}.102 & .899 & .181 & .140\end{array}$

$\begin{array}{llll}.101 & .915 & .232 & .136\end{array}$

$\begin{array}{llll}.101 & .933 & .230 & .132\end{array}$

$\begin{array}{llll}.101 & .870 & .278 & .103\end{array}$

$\begin{array}{llll}.111 & .801 & .274 & .085\end{array}$

$\begin{array}{llll}.157 & .535 & .072 & .141\end{array}$ 
TABLE VI

ROTATED FACTOR MATRIX, THE 46TH GENERAL ASSEMBLY (continued)

Variables

F1 F2 $\quad$ F3 $\quad$ F4

199

Israeli-occupied territories

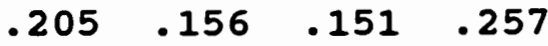

201

Assistance to the Palestinian

$\begin{array}{llll}.172 & .301 & .319 & .291\end{array}$

210

Developing countries:economic

$.595 \quad .078 \quad .118 \quad .185$

216

Kuwait:environmental

$.095-.053 \quad .147 \quad .063$

84 International Convention on

$.791-.006 \quad .092 \quad .029$

87

Self-determination: improvement

.757

89 Mercenaries:use of

$\begin{array}{llll}.726 & .065 & .044 & .024\end{array}$

95 Women:advancement

$.182 \quad .157 \quad .148 \quad .245$

117 Human rights:improvement

$\begin{array}{llll}.805 & .004 \quad .051 \quad .024\end{array}$

130 Elections:international

134 Iraq:human rights situation

$.755 \quad .193 \quad .017-.028$

135

Kuwait:human rights

$.020-.001 \quad .041-.023$

137

Elections:enhancing principle

$\begin{array}{llll}-.022 \quad .021 \quad .004 & -.047\end{array}$

153

African institute for crime

$.064 \quad .043-.033 \quad .023$

63 Non-self governing territory

64 Decolonization

$.662 \quad .159 \quad .056 \quad .033$

65 Decolonization

$.190 \quad .140-.009 \quad .585$

$\begin{array}{llll}.835 & .107 \quad .072 \quad .052\end{array}$

52 New International Economic

$.856 \quad .049 \quad .111 \quad .077$

$.629 \quad .065 \quad .099-.002$

nuclear weapons. Those four factors represent main issues of the Forty-sixth Session.

The plot of "humanitarian and other global issues" and "Israeli occupied territories" (Figure 5) shows two clusters. One cluster represents a bloc of developing countries, and the other represents the developed countries, to which Japan belongs. Japan took a negative stance on "humanitarian and other global issues," with other industrialized countries. It abstained from those resolutions which aimed at the protection of human rights. Japan, with a majority of nations, took a pro-Arab/anti-Israel stance, and affirmed all 
of the question dealing with the Israeli-occupied territories. On these particular questions, the USSR joined the United states and Israel in taking a pro-Israel position. Figure 6 shows a plot of "Israeli-occupied territories" with "Palestinian refugees" with only one cluster which, contains developed and developing countries. Israel, United States, USSR, and Dominica isolated themselves from the cluster. Japan placed itself in the center of the big cluster, which indicates a relatively pro-Arab stance, but it shows a lessening of the pro-Arab stance taken in 1988. On the issues of Palestinian refugees, Japan again took a neutral position, which indicates anti-Israel votes.

Figure 7 shows rotated scores on "humanitarian and other global issues" and "arms control and disarmament issues." There is a widely spread cluster, which includes Japan. The United states and Great Britain took extremely negative positions on issues of arms reduction. It means that they tended to reject the proposals of arms reduction. Japan's stance on issues of arms reduction was slightly positive, which suggests it abstained or affirmed those resolutions with other countries.

In sum, Japan never isolated itself from the bloc of industrialized countries, especially G-7 countries, on any issues in the Forty-sixth session. 
Figure 5. Factor scores on "humanitarian and other global issues" (Vertical) and "Israeli-occupied territories" (Horizon) at the 46 th General Assembly

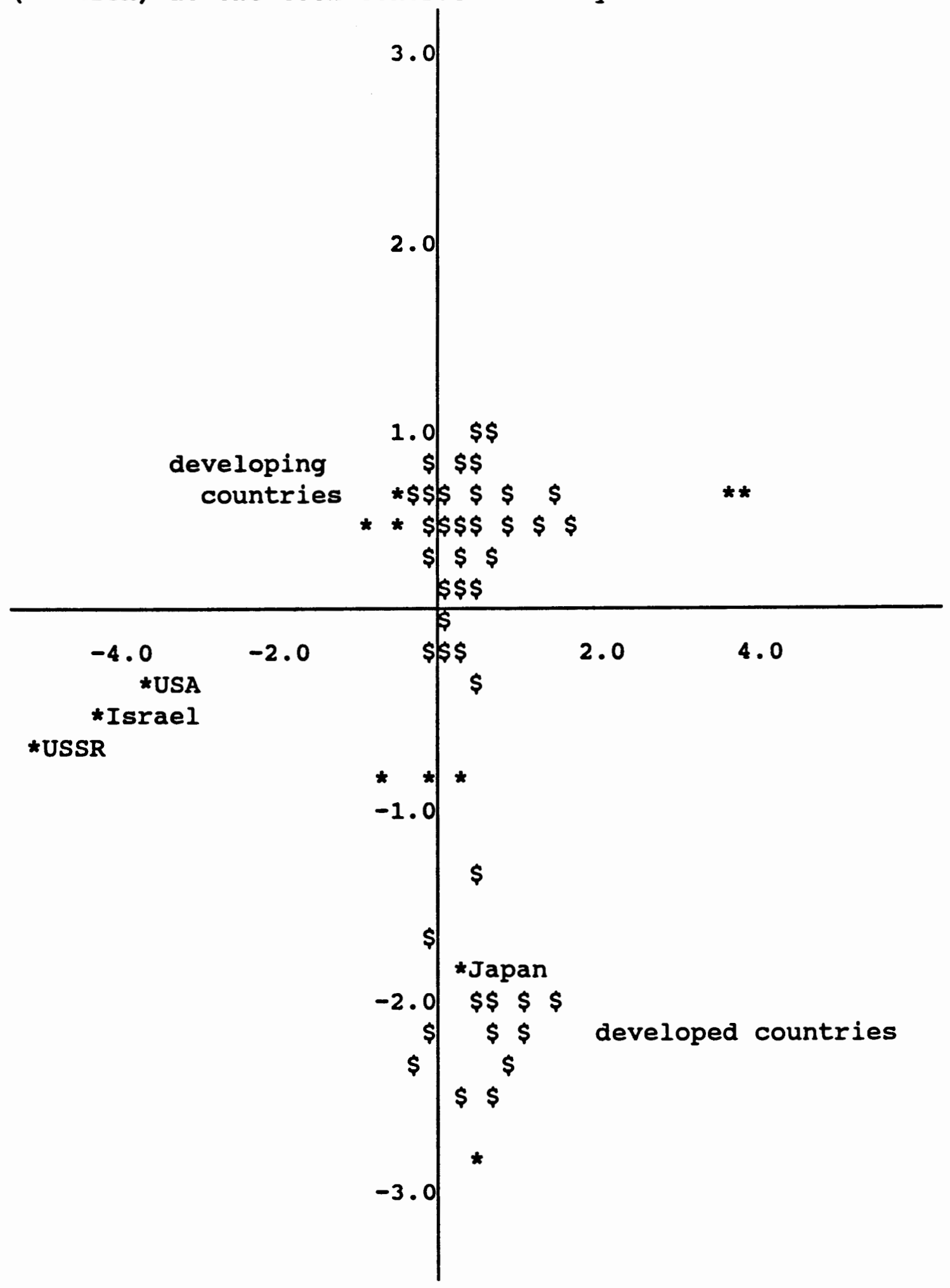


Figure 6. Factor scores on "Israeli-occupied territories" (Vertical) and "Palestine refugees' issues"(Horizon) at the 46th General Assembly

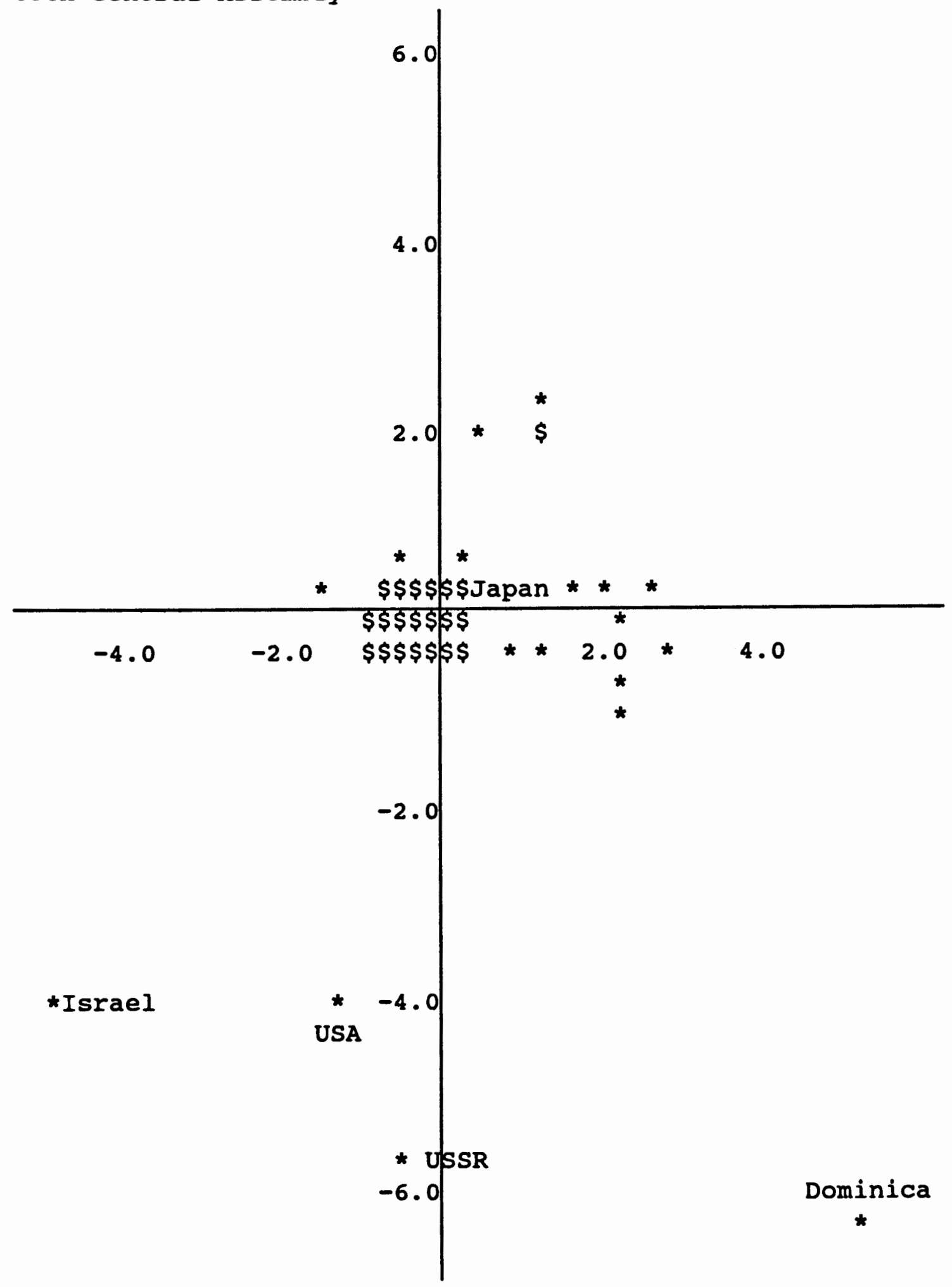


Figure 7. Factor scores on "humanitarian and other global issues" (Vertical) and "arms control and disarmament" (Horizon) at the 46 th General Assembly

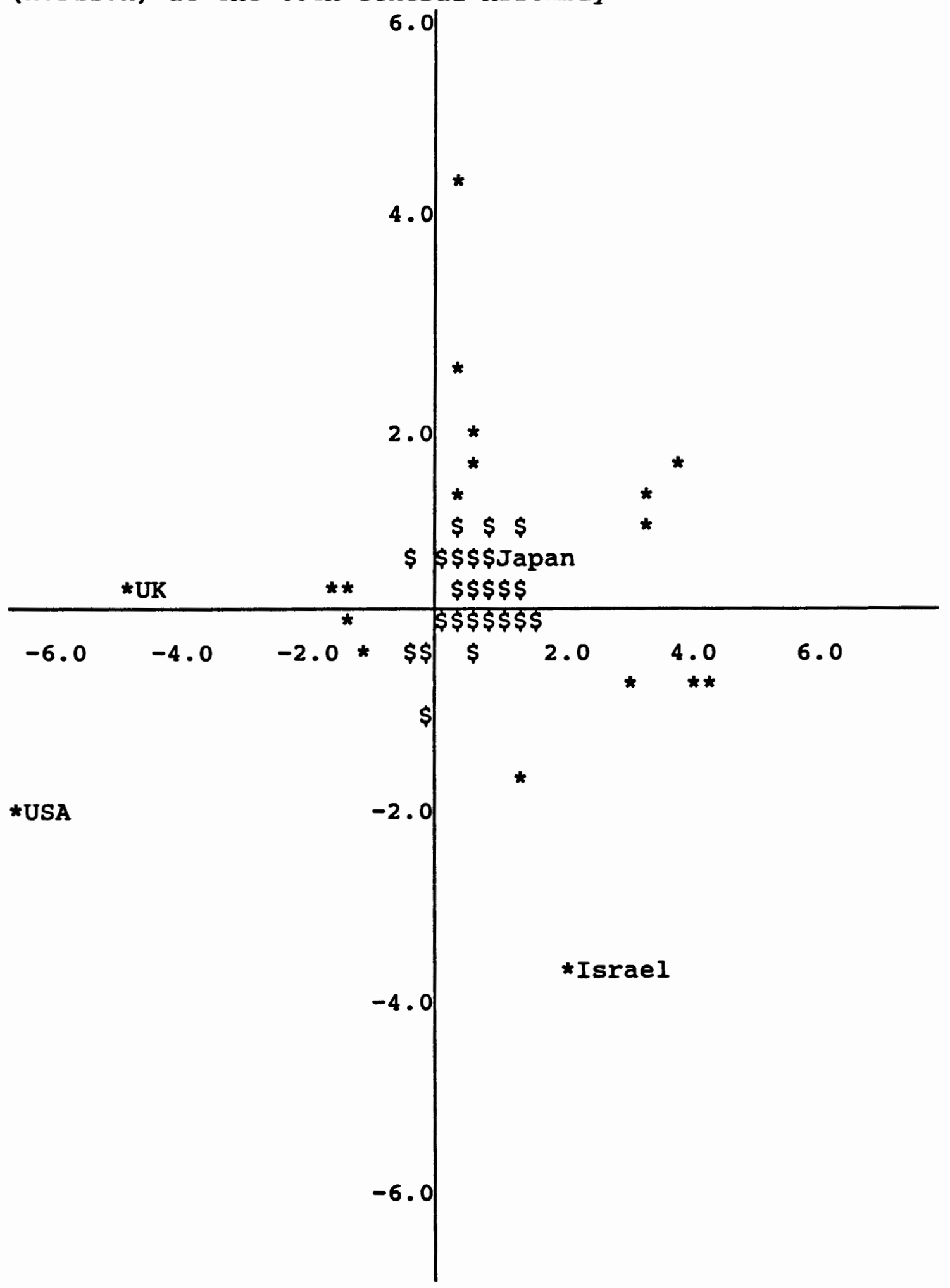


Conclusion

Throughout the Forty-Third and the Forty-sixth General Assemblies, Japan always voted with the other industrial countries: it never appeared with the Asian countries. Especially, Japan's concurrences with G-7 countries were very significant throughout the years. Because cooperation with Western countries has been priority for Japan, discussion in meetings which provide for mutual coordination have affected its foreign-policy behavior. Moreover, since Japan is not involved in any other institutional policy-coordinating mechanism on political issues, the G-7 is the only possible framework for effective policy consultation and coordination. Therefore, it is reasonable to observe Japan's solidarity with G-7 members in the General Assembly.

On issues of arms reduction, Japan's voting behavior is neutral. It took the same position as other industrialized countries. Although the official statements repeated its positive, active pacifistic position, and were strongly against use and threats of use of nuclear weapons and other weapons, and favored a nuclear freeze, this policy did not appear in Japan's voting behavior in the UNGA. Instead, Japan abstained from a number of resolutions concerning arms control.

on Middle East peace problems, it carefully took the same position as other G-7 members, except the United states, which took an extreme pro-Israel position. Japan tended to 
take a pro-Arab position, even though a number of abstentions can not be ignored. Observably, its pro-Arab stance in 1988 was much stronger than that in 1991. While there seemed to be no consistent policy toward these issues, Japan did not necessarily follow U.S. policy, either.

Japan's voting behavior on human rights issues did not reflect its philosophy that human rights are a universal value due all humanity. The voting score of human rights issues shows negative score in 1988 and 1991. However, since the concurrence with other developed nations on these issues was very high, Japan's position on human rights issues was not so different from those of other industrialized countries. The real problem of Japan's voting behavior on this issue is a large number of abstention which made its position relatively negative.

There are some changes in the voting alignment between 1988 and 1991 sessions because of the end of the cold war. There was no longer bloc solidarity between Eastern European countries and USSR. In 1991, the USSR closely cooperated with G-7 states. However, it did not affect Japan's voting behavior in the period. Japan, in the Forty-Third and the Forty-Sixth Sessions, cooperated with all G-7 members except the United states. I believe that the annual summit meetings are clearly an important factor in Japan's foreign-policy behavior.

Factor analysis provided the group cohesion that shows 
Japan belongs to the Western democratic states, especially G7 countries. Furthermore, this study found that Japan's voting behavior did not reflect its stated foreign policy. Moreover, there were a number of abstentions on issues, which can be interpreted as mild doubt, a disinclination to go on record as supporting or opposing some idea, lack of timely instruction from home, cross-pressures resulting from the fact that friendly states are not all taking the same view, or strong opposition to some part of a decision. ${ }^{91}$ The precise meaning of any abstention needs further investigation. The next chapter will analyze the gap between Japan's foreign policy (a set of official guidelines) and its foreign-policy behavior (implementation of foreign policy). At the same time, it will seek explanations for Japan's abstentions. 
CHAPTER IV

A COMPARISON OF FOREIGN POLICY TO FOREIGN-POLICY BEHAVIOR

In this chapter, Japan's professed foreign policy and its foreign-policy behavior will be compared and analyzed issue by issue based on findings in the previous chapters. The chapter further seeks to explain the contradiction between Japan's stated positions and its voting behavior in the UNGA. It addresses such conflicts by focusing on domestic cultural and historical constraints, and inter- and multistate factors that may affect foreign-policy behavior. The chapter also gives attention to the critical events of the period between 1988 and 1992, dominated by the end of the cold war and the Gulf crisis, that may have influenced Japan's foreign policy and its implementation. Issues that were major agenda items in the United Nations and recent primary concerns in Japan's foreign policy include arms control and disarmament; economic development in developing countries; humanitarian issues; the Middle East peace problem; and the global environment.

\section{JAPAN'S BASIC STANCE}

The Government of Japan sought to maintain its role as a member of both the west and a participant in the Asian 
community during the cold war. However, as illustrated by the voting maps, Japan has always put itself in the group of industrial countries. There is no evidence from the voting maps that Asian countries influenced Japan's voting behavior. Japan's voting records do not reveal cooperation with other Asian nations. In other words, Japan's voting behavior does not reflect its supposedly dual position in world affairs. Japan's fundamental position as a member of the Western industrial bloc is much stronger. It can be said that Japan is aware of its geographic, historical and regional responsibility as a member of the Asia-Pacific; but its much stronger roles are as a upholder of the Western ideology of free, democratic, market economies and as an intermediator between Western nations and Asian countries.

Japan acquired the status of a world economic power in the mid-1970s. It has consolidated its position, not only in economic but also the political and security dimensions of the Western partnership, since the early 1980s. The annual G7 summit meetings have given Japan a platform to express its opinion about world problems as seen from its corner of Asia. At earlier G-7 meetings, Japan was often criticized by Western allies because of its soaring trade surplus with the Western industrialized countries. At the Toronto summit in 1988, however, Japan played an active role as an intermediator presenting Asia's interests, including those of the newly industrializing economies. Japan demanded 
international aid to the Philippines and support for the Seoul Olympic Games, and recalled the need for a peace settlement in Cambodia. ${ }^{92}$

As a member of the Asian community, Japan has aggressively cultivated friendly ties with the Association of South-east Asian Nations (ASEAN -- Thailand, Singapore, Indonesia, Philippines, Brunei, Malaysia) since the announcement of the "Fukuda Doctrine." When Prime Minister Fukuda visited the ASEAN countries in 1978, he announced that Japan would never again become a military power, would establish ties on an equal footing with governments of the region and would strive to develop "heart to heart relationships" with Asian countries. This expression appealed to people's emotions and had an even more profound effect than the commitment to economic assistance. ${ }^{93}$ since 1978 , Japan as a regular participant in annual dialogue with the ASEAN Foreign Ministers, has taken on added economic responsibilities. Moreover, Japan has consistently supported the ASEAN policy in favor of a comprehensive political settlement of the Cambodian conflict. Tokyo has pledged its support for and participation in the U.N.-administered postwar settlement in Cambodia and the post-conflict

92 Shiro Saito, Japan at the Summit: Japan's role in the Western Alliance and Asian Pacific co-operation (New York: Routledge, 1990) 97.

93 Masahide Shibusawa, Japan and the Asian Pacific Region (New York: Routledge, 1989) 106. 
reconstruction of the Indochinese economies. 94

Since a number of security issues in East Asia remain unsolved despite the end of the cold war, Japan maintains a strong interest in solving regional disputes. During the July 1991 ASEAN Post-Ministerial Conference (ASEAN-PMC) in Kulua Lumpur, Japan's Foreign Minister, Taro Nakayama, proposed the institutionalization of an annual forum on regional security matters at which ASEAN and other interested parties could exchange views on the matters. Tokyo was stimulated by similar proposals announced by Mikhail Gorbachev in the middle of the 1980s, and by Australia's call for a Conference on security and cooperation in Asia in $1990 .{ }^{95}$ Although Tokyo's intention was not to organize a regional-wide security system, but to promote political dialogue, Japan could not avoid the suspicions of some Asian states. In addition, initially the United states under the Bush administration showed little interest in this proposal, clearly preferring the existing U.S. structure of bilateral security pacts with Japan, South Korea, Australia, Thailand,

94 Tsuneo Akaha and Frank Langdon, "Introduction: Japan and the Posthegemonic World," Japan in the Posthegemonic World (Boulder: Rienner, 1993) 12 .

95 Yoshida Soeya, "The Evolution of Japanese Thinking and policies on Cooperative Security in the 1980s and 1990s," Australian Journal of International Affairs, Vol.XXXXVIII, No.1, MaY 1994: 87. 
and the Philippines. 96 In 1992, the leader of the ASEAN countries finally agreed to intensify external dialogue on political security matters by using the ASEAN-PMC structure. Under the Clinton administration U.S. policy has been to endorse the political dialogue in the ASEAN-PMC (though it has not made a clear desire to erect an alternative security structure, as opposed to increased burden-sharing within a continuing framework of the U.S.-led alliance system).97 Eventually, Japan's effort to promote political dialogue was remunerated.

Compared with the security agenda, Japan found a positive and active role promoting economic cooperation in the region. It has provided a persuasive set of economic inducements, including foreign aid, commercial loans, technological transfer, direct investment, and preferential access to the Japanese market. As a member of the Asian community, Japan has undertaken impressive economic responsibilities in the region.

Just as growing economic regionalism has taken hold in Europe and North America, in the Asia-Pacific there is increasing enthusiasm for a regional trade framework among some nations. The Asian Pacific Economic Cooperation

96 Kenneth B. Pyle, The Japanese ouestion: Power and purpose in a New Era (Washington, D.C.: The AEI Press, 1992) 145.

97 Charles E. Morrison, "The United States and Cooperation in the Asia-Pacific," Australian Journal of International Affairs, Vol.XXXXVIII, No.1, May 1994: 72-73. 
Conference (APEC) in November 1989 was held in Canberra at Australian Prime Minister Bob Hawke's initiative, and was enthusiastically supported by South Korea. Yet Japan did not move actively until the United states, which had not been included in the initial Australian scheme, decided to join it. Japan's reluctance to formulate a regional framework stems from its dependence on the U.S. market, as well as from its residual guilt in the postwar era. The latter was exacerbated by repeated warnings from Asian leaders about Japan's "new ambition. "98 Since 1991, China, Taiwan, and Hong Kong joined the twelve original participants of APEC: the six members of ASEAN, the United States, Canada, Japan, South Korea, Australia, and New Zealand. By increasing the number of participants, APEC can be a forum in which a regional economic cooperation is promoted and regional uncertainties are reduced. It is a preferable framework for Japan since it does not force Japan to make a choice between North America and Asian trade partners.

As Japan's importance increases in the Western summits and the ASEAN dialogue, it seems that Japan has begun to overcome the traditional conflict between its roles in the West and Asia, in both the economic and the political dimensions. Japan has done this by playing an intermediary

98 Yoichi Funabashi, "Introduction: Japan's International Agenda for the 1990s," Japan's International Agenda, ed. Yoichi Funabashi (New York: New York University Press, 1994) 9. 
role between the West and Asia. However, it has neither found a meaningful way to link the two roles, nor has it played a major part in either camp in regional and global issues.

\section{ARMS CONTROL AND DISARMAMENT ISSUES}

Since the arms race was mainly prompted by the cold war, the disintegration of the Soviet Union and the collapse of the communist governments of Eastern Europe were supposed to create a less violent world. To some extent negotiations on arms control between the United states and the soviet Union reduced nuclear and conventional war arsenals. However, the end of the cold war has also made clear the need for more comprehensive arms control. The East European countries have left the control of the former soviet bloc's thousands of warheads in doubt. There are fears that these economically troubled countries, hungry for cash, will sell nuclear weapons and technology to developing nations in Asia and elsewhere. An example of proliferation of weapons was clearly observed during Persian Gulf War in Iraq's use of Scud missiles. Further, it was revealed by the International Atomic Energy Agency (IAEA) that Iraq had secretly produced enriched uranium, which could be used as a material for nuclear weapons.99 In addition, there is evidence that several countries, including India, Pakistan, and North Korea, have the capacity to produce nuclear weapons.

99 Ministry of Foreign Affairs, Japan, 1991, 97. 
Concerning arms control and disarmament issues, the Government of Japan has long urged the elimination of nuclear weapons and other weapons of mass destruction. However, despite a number of official statements which support world disarmament, Japan's voting behavior in the UNGA on disarmament issues has been inconsistent. Even on issues of nuclear weapons and nuclear war, Japan often abstained, and sometimes voted against arms control resolutions. Japan's voting behavior at the Forty-Third and Forty-sixth sessions shows a reluctance to respond actively on disarmament issues. For example, in the Forty-Third Session, Japan abstained from the resolutions related to issues of nuclear weapons, including: "Cessation of the nuclear-arms race and nuclear disarmament,"100 which reaffirmed that both bilateral and multilateral negotiations on the nuclear and space arms race are by nature complementary to one another, and requested the Conference on Disarmament to establish an ad hoc committee at the beginning of its 1989 session; and "Prevention of nuclear war,"101 which requested the Conference on Disarmament to undertake, as a matter of the highest priority, negotiations with a view to achieving agreement on appropriate and

100 Resolution 43/78E: No-13 (Belgium, Canada, France, West Germany, Italy, Luxembourg, Netherlands, Norway, Portugal, Spain, Turkey); Abstain-5 (Australia, Denmark, Iceland, Israel, Japan); Yes-other 135 countries.

101 Resolution 43/78F: No-3 (France, UK, USA); Abstain-14 (Belgium, Canada, Denmark, West Germany, Iceland, Israel, Italy, Japan, Luxembourg, Netherlands, Norway, Portugal, Spain, Turkey); Yes-other 136 countries. 
practical measures that could be negotiated and adopted individually for the prevention of nuclear war and to establish for that purpose an ad hoc committee on the subjects at the beginning of its 1989 session. Japan voted against "nuclear weapon freeze," 102 which urged the United States and the Soviet Union, as the two major nuclear-weapon states, to agree to an immediate nuclear arms freeze, and called upon all nuclear-weapon states to agree through a joint declaration, to a comprehensive nuclear arms freeze. It also voted against "convention on the prohibition of use of nuclear weapons," ${ }^{103}$ which reiterated its request to the Conference on Disarmament to commence negotiations, in order to reach agreement on an international convention prohibiting the use or threat of use of nuclear weapons under any circumstances. In the Forty-Sixth Session, it abstained on such resolutions of anti-war measures of the "convention on the prohibition of nuclear weapons," 104 and a "comprehensive

102 Resolution 43/76B: No-12 (Belgium, Canada, France, West Germany, Israel, Italy, Japan, Luxembourg, Netherlands, Turkey, UK, USA); Abstain-3 (China, Iceland, Spain); Yesother 135 countries.

103 Resolution 43/76E: No-17 (Australia, Belgium, canada, Denmark, France, West Germany, Iceland, Italy, Luxembourg, Netherlands, New Zealand); Abstain-4 (Greece, Ireland, Israel, Japan); Yes-other 133 countries.

104 Resolution 46/37D: No-16 (Australia, Belgium, Canada, Denmark, France, Germany, Italy, Luxembourg, Netherlands, New Zealand, Norway, Portugal, Spain, Turkey, UK, USA); Abstain23 (Albania, Argentina, Austria, Bulgaria, Czechoslovakia, Estonia, Finland, Grenada, Hungary, Iceland, Ireland, Israel, Japan, Latvia, Liechtenstein, Lithuania, Marshal Islands, Poland, Republic of Korea, Romania, Samoa, San Marino, 
programme of disarmament, "105 which requested the conference on Disarmament to reestablish, at the beginning of its 1992 session, the Ad Hoc Committee on the Comprehensive Programme of Disarmament.

Japan's abstentions from sensitive disarmament issues seem not to reflect its foreign policy of ultimate elimination of nuclear weapons and other weapons. Rather, its voting behavior seems to be the result of prioritizing cooperation with the Western nations. The United States and the United Kingdom tended to oppose disarmament issues, and when they did so, Japan tended to either abstain or vote against. This tendency can be seen in the voting behavior of other Western nations such as Australia, Canada, France, Germany, and Italy. Hence, Japan's voting concurrence with these countries was high on those issues.

Since its defeat in World War II, Japan has promoted national arms control based on the provisions of its Peace Constitution. Its adoption of the Three Non-Nuclear Principles and the Three Principles on Arms Control have been highly admired by the world community. In the 1970s, Japan

Sweden); Yes-other 121 countries.

105 Resolution 46/38B: No-6 (Belgium, France, Ghana, Netherlands, UK, USA); Abstain-31 (Albania, Argentina, Australia, Austria, Bulgaria, Canada, Czechoslovakia, Denmark, Estonia, finland, Grenada, Hungary, Iceland, Ireland, Italy, Japan, Latvia, Liechtenstein, Lithuania, Luxembourg, Marshal Islands, New Zealand, Norway, Poland, Portugal, Rep. of Korea, Romania, Spain, Sweden, Turkey, USSR); Yes-other 123 countries. 
played a considerable role in global arms control in the context of the Non-Proliferation Treaty (NPT); and at the beginning of the 1980s, it began to voice concern about INF. However, despite a high profile on arms control and disarmament on the national level, Japan has not had an effective policy on the regional or international level.

The discrepancy may be explained by the dichotomy within Japan's defense policy. Japan's unilateral arms control and disarmament measures, which were based on the government's interpretation of the Peace constitution, have always been at variance with security policies deriving from the JapaneseAmerican security treaty. ${ }^{106}$

As the Government of Japan has prioritized its national security upon a fundamental base of international peace, Japan has had to depend on the United States for its security given the restriction of the Japanese Peace Constitution. This has required Japan to exert maximum efforts to maintain and strengthen the credibility of Japan-U.S. security arrangements. In realistic terms, such a national security policy was reasonable during the cold war and may still be necessary given the global uncertainties of the post-cold war. Security in the Asia Pacific, for example, is still complicated by the conflict in Korea, China's rise, and the unsettled politics of post-conflict Cambodia. For security in Responsibilities (Atlantic Highlands: The Athlone Press, 1990) 5 . 
the region, the Japanese government seemingly believes vigilance and military ties with the United states should be preserved and enhanced. Without strong ties with the United States, Japan's relationship with all its neighbors -including the United States -- would be likely to deteriorate. ${ }^{107}$ Therefore, Japan considers that there is no feasible alternative to working closely with the United states on international security issues.

In 1980, Japan joined with the United States in the Systems Science and Technology Forum, which was established at the Pentagon's behest to usher in numerous defense cooperation possibilities. ${ }^{108}$ Japan has endorsed selfcontainment policies such as an arms-exports ban and the Three Non-Nuclear Principles, but the government seems to exclude importing arms technology. Japan's technological cooperation with the U.S. may be motivated by Japan's fear of losing technological and commercial advantages, as well as its obligation within the security treaty. Security ties with the U.S. further strain the application of the Three Principles on Arms Export. In 1983, the Japanese government decided not to apply these principles to the United States.

Even though the promotion of disarmament is Japan's

107 Takashi Inoguchi, Japan's Foreign Policy in an Era of Global Change (New York: St. Martin's Press, 1993) 63.

108 Susan J. Pharr, "Japan's Defensive Foreign Policy and the Politics of Burden Sharing, "Japan's Foreign Policy After the Cold War (New York: M.E. Sharpe, Inc., 1993) 250. 
basic policy, alliance with the United States seems to be the most important factor in Japan's foreign policy. To prevent further proliferation of nuclear weapons and other weapons, Japan, as the only nation to experience the horrors of the atomic bomb, seems to devote its special efforts to launching new guidelines that strengthen the export control system on weapons and related items. But in reality, Japan has worked closely with the U.S. in drawing up the guidelines over the past years. 109

In sum, the discrepancy of Japan's arms control and disarmament policy and its policy behavior lies in contradictions within Japan's defence policy. The contradictions stem from the security relations with the United States and commercial advantages. As long as Japan depends on the security arrangements with the U.S., it will continue to be heavily influenced in its foreign-policy behavior on international security issues, including disarmament issues, by U.S. preferences.

\section{THE MIDDLE EAST PEACE PROBLEM}

Throughout the years, Japan's voting behavior on issues of Middle East peace was the same as that of industrialized countries that took a pro-Arab stance, excepting the United States, which supported Israel. It is no surprise that Japan,

109 Ai Nakajima, "Tokyo seeking bigger say in global nuclear controls," The Nikkei Weekly, Vol.Xxx, No.15, March 28, 1992: 2 . 
as well as European countries, took pro-Arab position, since these states are vulnerable to reduced petroleum supplies from the Middle East whereas the United States is less vulnerable. Moreover, on Middle East issues, because Japan lacks a coherent foreign policy (as reviewed in Chapter II), it tended to follow the lead of the industrialized European countries. Without a concrete Middle East policy of its own, Japan maintained solidarity with those nations in the General Assembly. Thus there is no gap to fill between Japan's Middle East policy and its voting behavior. This section is devoted to a detailed examination of Japan's lack of Middle East policy.

Until the oil crisis of 1973, Middle East was not among Japan's vital interests and the Government of Japan did not have a clear foreign policy toward the region. Until that time, Japan's Middle East policy, as well as its foreign policy in general, had often been criticized for being absolutely dependent on the United States. But the need for oil drove Japan to break ranks with the United States in its dealing with the Middle East, henceforward falling into step with the European community nations instead. Since 1973, Japan's basic policy toward the Middle East, like most Western countries', has aimed at securing dependable supplies of oil, and it has made efforts to prevent military and political instability that could jeopardize these supplies. During the oil crisis, Japan was forced to make a 
crucial decision to ensure its economic survival. The country was under the threat of reduction of its supply of Arab oil and accused of siding with Israel. Because the United States maintained a special alliance with Israel, Japan risked harming its relations with the United states by taking a proArab position.

In October 1973, the organization of Arab Petroleum Exporting Countries (OAPEC) classified Japan as an "unfriendly" nation as regards the Arab cause in the fourth Middle East war, and announced restrictions on its members' crude-oil exports to Japan. ${ }^{110}$ In November 22 , 1973, the policy statement of Chief Cabinet secretary Nikaido Susumu represented Japan's first solo initiative: 1) The inadmissibility of acquisition and occupation of any territories by use of force; 2) the withdrawal of Israeli forces from all the territories occupied in the 1967 war; 3) respect for the integrity and security of the territories of all countries in the area and the need of guarantees to that end; and 4) recognition of and respect for the legitimate rights of the Palestinian people in accordance with the Charter of the United Nations in bringing about a just and

110 Hiroshi Shimizu, "The Japanese Trade contract with the Middle East: Lessons from the Pre-Oil Period," Japan in the Contemporary Middle East, ed. Kaoru Sugihara and J.A. Allan (New York: Routledge, 1993) 51. 
lasting peace in the Middle East. ${ }^{111}$ These principles were adopted from the U.N. resolutions. As reviewed in chapter II (p.44), Japan's current policy guideline has not changed since Nikaido's policy statement. On this point, Japan has taken a pro-Arab/anti-Israel position, contrary to the US stance, because for the Japanese government it seemed the only possible way to ensure the nation's economic survival. of course Japan's decision was welcomed by the Arabs and the restrictions on Japanese purchases of petroleum were lifted in December, 1973. ${ }^{112}$ Since then, the Japanese government has offered technical and financial assistance for the economic development of the oil-producing states, with the main purpose of seeking favor from these countries for the steady supply of crude oil. Unlike other industrial states, because the Japanese government has kept itself away from political involvement in the region, Arab states seemed to favor Japanese technical and economic cooperation.

In 1976, the PLO opened an office in Tokyo, and Arafat's first visit to Japan occurred in 1981. At this time, however, the Japanese government did not recognize the PLO as the sole legitimate representative of the Palestinian people. During the 1970s and early 1980s, Japan's attitudes towards Israel could be basically defined as cool and indifferent, and the

111 Cited by Naramoto Eisuke, "Japan Aligned with the PLO," Japan Quarterly, Vol.XXXVII, No.1, January-March 1990: 20 .

112 Ibid. 
tension between Japan and the United States over the Middle East policy continued. Especially, Japanese compliance with the Arab economic boycott of Israel was a source of frustration for pro-Israel lobby in the United states. However, since U.S. friendship was vital to Japan, the Japanese government neither took any active role on the issue, nor continued to develop its Middle East policy.

During the 1980 s Japan had gradually shifted its stance because of a changing Middle East situation. After the second oil crisis of 1979, the power of Arab oil declined, and Japan's pro-Arab policy began to be adjusted. ${ }^{113}$ Japan gradually relied less on Middle East oil, due to an oil glut and the increased value of the yen, as well as successful efforts in energy conservation and diversification of its oil supply. In addition, the Iran-Iraq war split the unity of Arabs and Iran replaced Israel as the most immediate threat to the region. ${ }^{114}$ Third, Egypt opened the door to Israel. After Egypt had recognized the state of Israel, and established diplomatic ties with it, Japan as well as other countries, decided to deal with Israel. ${ }^{115}$ For example, in 1985, Foreign Minister of Israel Yitzhak Shamir visited Japan, and Prime Minister Uno made a visit to Israel in 1988 .

113 Asai Nobuo, "Walking a Tightrope in the Middle East," Japan Quarterly, Vol.XXXIX, No.4, October-December 1991: 409 . 114 Ibid. , 410.

115 Ibid. 
After developing its relationship with Israel, Japan's stance in the Middle East became more ambiguous. Japan had to keep balanced ties with the Arabs, as well as Israel, while it had to maintain harmonious relations with the United states.

Finally, in 1990-1991, the crisis in the Gulf deepened and widened the split of the united Arab front. It became difficult for Japan to adjust its ties in the Middle East among the Arab states, Israel, and Iran. Japan also had to consider balancing relations with the pro- and anti-Irag factions with in the Arab world. ${ }^{116}$ During the Gulf crisis, Japan realized the necessity of cooperation with the United States. Powerful Jewish lobbies exerted increasing influence on the Bush Administration to put the subject of Japanese adherence to the Arab boycott on the agenda of U.S.-Japanese trade negotiations. ${ }^{117}$ In April 1991, Prime Minister Kaifu ended the trade embargo. Kaifu's remarks were regarded as a "turning point" for Japanese policy towards the region. Japan's rapidly changed stance also appeared in the voting maps in 1988 and 1991. It found it easy to expand and consolidate its relations with the anti-Iraq faction sided with the United States, and therefore it expanded ties with Israel, too. Japan's Middle East policy was determined the

116 Ibid., 415.

117 Akifumi Ikeda, "Japan's Relations with Israel," Japan in the Contemporary Middle East, ed. Kaoru Sugihara and J.A. Allan (New York: Routledge, 1993) 155. 
need to have good relations with both the United States and oil-producing Arab states, while leaving its relationship with Israel.

Maintaining stability in the region does not seem an easy task because of religious, ethnic, and historical animosities. Since World War II, the region has experienced six major military conflicts. Besides the Iran-Iraq War and the Persian Gulf War, other four wars stemmed from the ArabIsraeli conflict, the most critical issue for regional stability. During the Gulf Crisis, Iraq fired Scud missiles into Israel in an attempt to justify its invasion of kuwait, but Iraq also clearly intended to provoke Israel into launching a counterattack that would escalate the Gulf War into an Arab-Israeli conflict. ${ }^{118}$

Japan has failed to develop much awareness of Middle East complexities primarily because Japan played no role in the historical process that preceded it: the breakup of the ottoman Empire and the British mandate for Palestine after World War I, and the establishment of Israel following World War II. ${ }^{119}$ Moreover, because Japan has been concerned only to secure access to oil, it has avoided embroilment in complex Arab-Israeli political issues. Finally, Japan gave up trying to understand the region's complexity, viewing it as one in

118 Yoshiji Nogami, "Japan's Middle East Policy in Transition," Japan Review of International Affairs, Vol.VII, No.2, Spring 1993: 109

119 Ibid., 109. 
which neither Western ideology nor Japanese common sense can be applied to solve its problems. ${ }^{120}$

The government of Japan has made attempts to negotiate with the parties involved in the Middle East conflict (chapter II, p.45). However, the results of the meetings were not impressive since Japan did not have much experience in developing new solutions to the Palestinian problem. Nor was Japan comfortable about forcing its morality upon a regional conflict which involved totally different religions, history, culture, and race. Moreover, the most influential actor was the United States. At that point, all Japan was able to offer was humanitarian aid to the Palestinian refugees through the United Nations.

Since the end of the cold war, the United States and Russia have coordinated their efforts to solve regional disputes arising from ethnic nationalism. In this setting, the United States has worked out a series of bilateral and multilateral negotiations, involving the six Gulf states, other Arab countries, Japan, the European Community, and Canada. Peace negotiation could not succeed without the efforts of the United States, but Japan, the EC, and Russia as well as Saudi Arabia helped sponsor the negotiations. Japan was expected to assume an active role in the multinational Middle East peace process that began in Moscow

120 Tatsuo Takeda, Nihon no Gaikou: Sekkyoku Gaikou no Jouken (Japan's Foreign Policy: Toward Active Diplomacy) (Tokyo: The Simul Press, 1990) 131. 
in January $1992 .^{121}$ It is to play a leading part in the environmental discussion, as well as coordinate working groups to cover regional arms control and security. This means that Japan needs to clarify its policy objectives and principles under all situations in the region.

overall, the problem in Japan's foreign-policy behavior on the Middle East issues lies in its lack of a clear and coherent foreign policy. The lack of a clear foreign policy seems to stem from a Japanese way of thinking, and the culture of the Japanese community as a whole. ${ }^{122}$ It can be said that Japan's Middle East policy has been defined by its oil-centered economic interest. Japan's trade, foreign aid, and investment in the region varied directly with the price of oil: when oil price rose, foreign aid, investment, and exports to the region increased, but when prices fell in the 1980s, Japanese perception of the strategic importance of the region slumped. ${ }^{123}$

Consequently, Japan's economic contributions to regional peace were all Japan could do, but its political contribution was not significant. Since Japan is neither a military power nor a political power, financial contributions are Japan's only way to deal with the Middle East, even though the region

121 Nogami, 112.

122 Yuzo Itagaki, Nihoni in yo Kakugo wa Dekiteiruka! (Are You Japanese Ready?) (Tokyo: KK Bestsellers, 1991) 87.

123 Lincoln, 219-220. 
is critical to Japanese economy. Japan's policy on the Middle East has been determined by pressures from the United States, as well as oil-producing Arab states. Japan has taken an ambivalent position without clearly defined goals, and ended up simply coping with the resulting situation when a crisis occurred.

\section{HUMAN RIGHTS ISSUES}

The issue of human rights, long regarded as an important principle regulating international relations, was raised in the international arena in relation to apartheid and the suppression of democracy by military regimes elsewhere. It has also been brought to bear on the repressive policies of certain governments (for example, Burma, China, and El Salvador), and it further includes problems of international and internal refugees. All these human rights problems have been getting attention in international organizations and some progress on human rights has been made through their efforts.

As noted in Chapter II, Japan's basic philosophy about human rights is that human rights are a universal value and are the basis for world peace and stability. In the Diplomatic Bluebook between 1988 and 1992, even though respect for human rights was expressed in general terms, Japan did not make any concrete policy or response to current human rights issues except refugee problem. It can be assumed 
that Japan wants to avoid expressing any official statement on sensitive human rights issues. To justify its position, the Japanese government uses an excuse that "rights" develop within a particular culture and political system so that national sovereignty must be respected, which contradicts its basic philosophy. ${ }^{124}$ The government usually holds that it may neither set specific international human rights standards nor impose sanctions against violating governments.

The United Nations, during the five years studied here, addressed human rights problems directly through a series of resolutions passed by the General Assembly. Japan's voting behavior on these issues in the Forty-Third session might be interpreted as a sign of reluctance to make any decisions. without exception, Japan abstained from human rights questions such as: "rights of peoples to peace,"125 which reaffirmed that the implementation of the right of peoples to peace constitutes a fundamental concern of each state; "international decade for the eradication of colonialism,"126 which declared the period 1990-2000 as the

124 John M. Peek, "Japan, the United Nations, and Human Rights," Asian Survey, Vol.XXXII, No.3, March 1992: 222.

125 Resolution 43/22: No-0; Abstain-29 (Australia, Austria, Belgium, Brazil, Canada, Denmark, Djibouti, Fiji, Finland, France, West Germany, Greece, Iceland, Ireland, Israel, Italy, Japan, Luxembourg, Netherlands, New Zealand, Norway, Portugal, Samoa, Senegal, Spain, Sweden, Turkey, UK, USA); Yes-other 118 countries.

126 Resolution 43/47: No-1 (USA); Abstain-20 (Australia, Belgium, Canada, Denmark, Finland, france, West Germany, Greece, Iceland, Ireland, Israel, Italy, Japan, Luxembourg, 
International Decade for Eradication of Colonialism, aiming at a world free from colonialism; "human rights and scientific and technological developments, "127 which stressed the importance of the implementation by all states of the provisions and principles contained in the Declaration on the Use of Scientific and Technological Progress in the Interests of Peace and for the Benefit of Mankind in order to promote human rights and fundamental freedoms; "indivisibility and interdependence of economic, social, cultural, civil, and political rights," ${ }^{128}$ which requested the secretary-General to enhance his efforts under the programme of advisory services to states in the implementation, promotion, and protection of the human rights and fundamental freedoms set forth in the International covenants on Human Rights and other United Nations instruments in the field of human rights; and many aspects of apartheid issues. Japan continued its silence on human rights issues in the Forty-sixth Session.

Netherlands, Norway, Portugal, Spain, Sweden, UK); Yes-other 135 countries.

127 Resolution 43/110: No-0; Abstain-24 (Australia, Austria, Belgium, Canada, Denmark, Finland, France, West Germany, Greece, Iceland, Ireland, Israel, Italy, Japan, Luxembourg, Netherlands, New Zealand, Norway, Portugal, Spain, Sweden, Turkey, UK, USA); Yes-other 133 countries.

128 Resolution 43/113: No-1 (USA); Abstain-23 (Austria, Belgium, Canada, Chile, Denmark, Finland, France, West Germany, Greece, Iceland, Ireland, Israel, Italy, Japan, Luxembourg, Netherlands, Norway, Portugal, Spain, Swaziland, Sweden, Turkey, UK); Yes-other 132 countries. 
Also on human rights issues, the Japanese government found great difficulty maintaining a dual stance that takes account of its membership in both the Western camp and the Asian community. Japan was faced with the prospect of choosing between positions defined on the one hand by the governments of the advanced West and various international and non-governmental organizations, and on the other hand, by the governments of Asian countries such as Indonesia, China, singapore, and Malaysia. Western nations prioritize economic liberalization, democratization, human rights, and environmental preservation, and believe that any violations against those values should be punished until corrected. For those countries, the universalization of democratic values is important. On the contrary, some Asian countries claim that Western liberalism, including democratization and human rights, detracts from their economic growth and political stability. In this respect, Japan has found itself in an awkward position in which it cannot take sides. As a result, Japan wound up abstaining on most of human rights issues.

Yet Japan has been very sensitive to human rights issues in Asia, notably China's suppression of political and human rights. After the Tiananmen suppression of 1989, Japan initially joined the West in condemning the actions by the Chinese government. However, the Japanese government became the first to lift its economic sanctions against the Chinese communist regime. It was the first to provide, initially in 
private, then publicly, multiple loans to the chinese government, and the first to send an official at the ministerial level to visit Beijing. ${ }^{129}$ In January 1991, Finance Minister Ryutaro Hashimoto visited China and Prime Minister Kaifu visited Beijing in August 1991. Prime Minister Miyazawa, who succeeded Kaifu, supported Prime Minister Li Peng of China and justified Japan's response: "Some countries may have pulled themselves out of absolute poverty, and for them, making a living is the most important for that country. Applying an abstract yardstick of human rights to foreign aid would not allow for effective development assistance." 130

This tendency can be seen Japan's reaction elsewhere in Asia. For example, when Burma's military seized power and killed hundreds of student protesters demanding democratization in September 1988, Japan followed the West in suspending aid but it never linked this action to the ruthless behavior of the Burmese military. Then in February 1989, Japan broke with the West and resumed economic aid for continuing projects as well as humanitarian aid.

On November 12, 1991, over 100 unarmed pro-independence East Timor demonstrators were killed in the town of Dili by Indonesian security forces. The Japanese government requested that Jakarta thoroughly investigate the case. Japan welcomed

129 Liu Binyan, "Human Rights Imperialism and SelfDetermination in Asia," New Perspectives Quarterly, Vol.IX, No.1, winter 1992: 31 .

130 Cited by Liu Binyan, 31-32. 
Indonesia's report of the investigation, including penalties for Army commanders. ${ }^{131}$ Although 262 Japanese Diet members petitioned the Miyazawa government to review its aid policies toward Indonesia, the Japanese government stated that there was no need to change economic cooperation policies. ${ }^{132}$ Like most other G-7 countries, Japan did not suspend aid or visits by government officials.

In Thailand, the elected government headed by Chatichai Choonhaven was toppled in February 1991 by a bloodless military coup. Western nations condemned the action and threatened aid stoppages and economic sanctions, but Japan noted a mere expression of regret and its intention not to consider changing ODA implementation. ${ }^{133}$ Later, on May 18, 1992, the military government under General suchinda Krapayoon declared an emergency in Bangkok, and army crushed a mass demonstration calling for an end of military rule, reportedly killing more than 100 people. At first, Japan did not condemn the bloodshed, only demanding that Thailand restore stability. The Japanese government did not suspend aid in the response to the situation while the U.S. suspended scheduled talks on resumption of already frozen aid and

131 Hisao Takagi, "Japan pursues own diplomacy on international human rights," The Nikkei Weekly, Vol.XXX, No.1528, August 1, 1992: 1-2.

132 David Arase, "Japanese Policy Toward Democracy and Human Rights in Asia," Asian Survey, Vol.XXXIII, No.10, October 1993: 947 .

133 Ibid., 948 . 
canceled a joint military drill.

As reviewed in chapter II, Japan's aid policies are supposed to be based on humanitarian considerations. Nevertheless, the Japanese government's reactions to violation of human rights in Asia seems to contradict its aid policy guidelines and indicated its political difficulty in following collective actions undertaken by Western nations. Japan's idealistic statements share a common view and basic policy with Western nations on human rights issues. Its reluctance to follow the Western philosophy on human rights has been justified by claiming that Japan's economic aid to Asian countries does not mean that Japan harbors a disrespect for human rights; only that Japan has a different approach. In practice, Japan's policy emphasis on economic development in Asia contrasts with Western priorities such as democratization, human rights, and environmental preservation. A former Japanese ambassador to the United Nations, Shizuo saito, has stated that "applying a formalistic response to a country like China, however, would only complicate matters, not only because of its vast size but also because such measures could have serious international political repercussions." ${ }^{134}$ He implied support of China's counterattack to the U.S., claiming that U.S. pressure on China's human rights violation was interference

134 Shizuo Saito, "The United Nations and the Issues of a Fluid Global Society," Japan Review of International Affairs, Vol.VII, No.3, Summer 1993: 241. 
in domestic affairs. Takakazu Kuriyama, a former vice foreign minister, said that "its [Japan's] approaches to human rights do not have to be identical to those of Washington, especially as our historical relations with Asian nations are different from those of the U.S. Some nations like China have a very idiosyncratic concept of human rights, and we have to understand that. "135

There are cultural and political constraints on the promotion of human rights in Japan. While there is a tradition of promoting citizens' rights, the concept of human rights is at best fuzzy among the public, which often associates human-rights activities with charity and voluntary work rather than political dissent and racial discrimination. ${ }^{136}$ Further, because of its wartime atrocities in Korea, China, and Southeast Asia, Japan feels that it is on weak moral ground when accusing its neighbors of humanrights violations. ${ }^{137}$ Japanese criticism of other Asian countries because of their human rights policies provokes suspicion of Japanese motives and leads to fears of a revival of prewar Japanese expansionism. Therefore, Japan often gives priority to maintaining good political relations with other

135 Cited by Hisao Takagi in "Similar ends, different means," The Nikkei Weekly, Vol.29. No.1495, December 7, 1991: 2 .

136 Louise do Rosario, "Reluctant Convert: Tokyo Begins to Speak up on Human rights," Far Eastern Economic Review, Vol. 153, No.34, August 22, 1991: 14-15.

137 Ibid. 
Asian nations over protection of individual human rights.

Because of the socio-cultural and political factors, Japan has difficulties implementing its policy on human rights issues. Therefore it continues to abstain from the issue, and relies instead on influencing human rights policies through bilateral and multilateral humanitarian aid.

ECONOMIC DEVELOPMENT IN DEVELOPING COUNTRIES

The economic contribution to developing countries by the Government of Japan has been noteworthy. For Japan, the term "foreign aid" is closely linked to economic development. Whenever the Japanese government talks about economic development in developing countries, without exception it assumes foreign aid is the true subject under discussion. As Japan has named expanding and enhancing its ODA to the developing countries as one of the three pillars of the International cooperation Initiative, Japan has been increasing its ODA disbursement. In 1989, it became the world's largest donor of ODA. In addition, Japan has worked on the solution for the accumulated debt problem in developing countries, introduced a financial recycling scheme, and announced the Fourth Medium-Term Target of ODA. Although the quantity of its economic assistance has been impressive, its quality and marked inclination towards Asia have become a question. To improve the quality, Japan introduced a country-by-country assistance plan so as to take 
into account requests made on a bilateral basis. In addition, Japan has been emphasizing grants and technical assistance over soft loans, and strengthening the administration of aid by training more experts to ensure the effective use of Japanese assistance. Yet the problem of regional inclination has not been solved, although Japanese government has gradually increased the proportion of its aid extended to non-Asian countries. In the ODA Charter in 1992, however, the Japanese government asserted that its economic assistance to Asia would continue to be its top priority.

Japan's voting behavior on these issues mostly reflected its basic policy that the steady economic development of the developing countries is of extreme importance to world peace and stability. Supporting the self-help efforts of developing countries facing a vicious circle of poverty is regarded by Tokyo as a responsibility of a major economic power. In the Forty-Third Session, Japan tended to vote in favor of proposals for economic development for developing countries. However, it abstained on a propose for a "durable solution for the debt crisis," ${ }^{138}$ which called on the international community to continue searching for durable, equitable, and mutually agreed growth oriented and development-oriented solution to the external indebtedness of developing countries, while the United states voted against it. The

138 Resolution 43/198: No-1 (USA); Abstain-1 (Japan); Yes-other 150 countries. 
voting records also reveal that Japan affirmed resolutions related to economic development while the United states abstained. Again it seems to have been U.S. influence on Japan's voting behavior even on issues of economic development. Another remark in the voting maps is that Japan's concurrence with other industrial countries, especially G-7 countries, on these issues was very high.

In the Forty-sixth session, most proposals concerning economic development were adopted without votes. It meant that all nations expressed a willingness to cooperate to solve the global economic problem. Only two resolutions related to economic development - that of "economic measures as a means of political and economic coercion against developing countries, "139 which called upon the international community to adopt urgent and effective measures to eliminate the use by some developed countries of unilateral economic coercive measuring against developing countries, and "progressive development of the principles and norms of international law related to the new international economic

Resolution 46/210: No-31 (Australia, Austria, Belgium, Bulgaria, Canada, DPR Korea, Czechoslovakia, Denmark, Estonia, Finland, France, Germany, Hungary, Iceland, Ireland, Israel, Italy, Japan, Latvia, Liechtenstein, Lithuania, Luxembourg, Netherlands, New Zealand, Norway, Poland, Portugal, Sweden, Turkey, UK, USA); Abstain-8 (Albania, Argentina, Greece, Panama, Rep. of Korea, Spain, Ukraine, USSR); Yes-other 97 countries. 
order,"140 which called upon the United Nations to initiate studies and make recommendations for the purpose of encouraging the progressive development of international law and its consideration -- were rejected by both Japan and the United States as well as other industrial nations.

overall Japan's foreign policy on issues of economic development is positive and it was reflected by its voting behavior. Its aid policy is considered to be gaining wide support both at home and abroad and portrayed as one matching its national and international interests. In other words, there were no domestic or external constraints that might hinder Japanese foreign policy on these issues. At home, most Japanese groups, including labor unions, the media, intellectuals, the business community, and all political parties, support foreign economic assistance. International and multinational organizations appreciate Japan's readiness to make up for American hesitation on increased multilateral aid since the early 1980 s. ${ }^{141}$ All recipient countries welcome Japan's efforts. At the same time, it works as an effective

140 Resolution 46/52: No-20 (Australia, Belgium, Canada, Denmark, Finland, Germany, Greece, Hungary, Iceland, Israel, Japan, Latvia, Lithuania, Luxembourg, Netherlands, New Zealand, Norway, Sweden, UK, USA); Abstain-17 (Albania, Argentina, Austria, Bulgaria, Czechoslovakia, France, Ireland, Italy, Liechtenstein, Panama, Poland, Portugal, Romania, Spain, Turkey, Ukraine, USSR); Yes-other 117 countries.

141 Dennis T. Yasutomo, "Why Aid? Japan as an 'Aid Great Power'," Pacific Affairs, Vol.LXII, No.4, winter 1989-90: 501. 
diplomatic tool from Tokyo's perspective. Aid serves as one means of restoring the severed relations with Asian nations conquered by Japan.

Although the Japanese government's official motive for aid is to form a bridge between North and South, the critical motivation is focused on securing raw material imports to protect national economic well-being. After the oil crisis of 1973, foreign aid has served as a major lubricant keeping the flow of oil to Japan, and it is a useful bargaining tool in relations with Persian Gulf combatants and their allies. ${ }^{142}$ Not only oil producing countries, but all the major recipients of foreign aid are major sources of raw materials. ${ }^{143}$ Lacking the possibility of using military force as a backup for protecting economic security, Japanese foreign aid gained increased importance as an economic security policy.

In addition, recently Japan has used foreign aid for more overtly international political or strategic purposes, such as when the Government of Japan announced new guidelines of foreign aid in 1992 (chapter II, pp.53-54). Although some of these guidelines, such as the degree of progress on democratization in respect for human rights, seem difficult to implement (see the discussion in the previous section of human rights issues), foreign aid could contribute to global

142 Ibid, 500.
143 Lincoln, 116.


peace and stability if the Government of Japan strictly and constantly applies the guidelines. So far its application of the guidelines to foreign aid is ambiguous and inconsistent. The government could not force the policy since about six out of the top ten recipients of bilateral aid (Bangladesh, China, Indonesia, Pakistan, Philippines, and Thailand) could not meet the guidelines. ${ }^{144}$

\section{GLOBAL ENVIRONMENTAL ISSUES}

As reviewed in chapter II, Japan's foreign policy on environmental issues is newly developed. The efforts to define an active role in international environmental policy began around 1988, when a spokesman for the Environmental Agency advanced the notion that the government could play a role in assisting developing countries with their environmental problems and complained of the government's lack of any long-term strategy to do so. ${ }^{145}$ The June 1992 Earth summit in Rio de Janeiro provided Japan a forum to respond to the global scope of environmental concerns.

In the Forty-Third and Forty-Sixth sessions, most of issues related to environment were adopted without votes. Japan's voting behavior on the environment was very positive. Japan affirmed every environmentally related issue, such as

\section{Ibid., 119.}

145 Kazuo Matsushita, "Japan offers Negative-Positive Ecological Model," Japan Economic Journal, Vol.XXVI, No.1321, July 16, 1988: 23 
"climate effects of nuclear war," ${ }^{146}$ which examined the report of the Secretary-General about a study on the climatic and potential physical effects of nuclear war, and "international cooperation to mitigate the environmental consequences in Kuwait and other countries in the region resulting from the situation between Iraq and Kuwait, "147 which emphasized the need to continue to take comprehensive measures to study and mitigate these environmental consequences in the region within a framework of sustained and coordinated international cooperation.

On environmental matters, Japan's voting behavior is affected largely by its foreign policy and there seem to be few domestic and international objections to promoting international environmental protection. Internationally, all major nations are dealing with environmental problems very positively, according to the voting records. At home, the Government and corporations have cooperated to improve global environment.

As an usual strategy, Japan foreign aid quickly became a central part of emerging environmental policy. At the annual industrial-nation economic summit meeting in 1988 , the Japanese government committed itself at the annual

146 Resolution 43/78D: No-0; Abstain-9 (Belgium, France, Luxembourg, Netherlands, Portugal, Turkey, UK, USA); Yesother 145 countries.

147 Resolution 46/216: No-0; Abstain-1 (Iraq); Yes-other 135 countries. 
industrial-nation economic summit meeting in 1988 to a threeyear, $\$ 2.2$ billion environmental foreign aid program. In June 1992, the prolonged Diet deliberation in Tokyo on the bill to enable Japanese troops to be dispatched overseas prevented Prime Minister Miyazawa from attending the Earth Summit, for which he was criticized. But that did not prevent Miyazawa's representatives from announcing Japan's contributions. Miyazawa announced Japan's decision to expand environmental aid to around $\$ 7$ billion to $\$ 7.7$ billion over a period of five years beginning in $1992 .{ }^{148}$

Along with purely financial aid, the Japanese government has been actively involved with funding and providing administrative guidance in a number of interesting and significant technological fields. These include internationally recognized progress on fuel cell technology, selective catalytic reduction for electric power plants, fluidized bed combustion, coal liquefaction, combined cycle powerplants, automobile efficiency, and solar photovoltaic cells. ${ }^{149}$

Yet as with other issues, Japan has to face the criticism that Japan lacks a global environmental consciousness, and had to be forced to eventually take any international initiative. The government often seeks to meet

148 "Tokyo commits to 5-year aid package for environmental protection," The Nikkel Weekly, vol.XXX, No.1522, June 20, 1992: 2 .

149 Lincoln, 153. 
these criticism with a burst of enthusiasm. Prime Minister Takeshita in 1989 told Environmental Agency officials that "we cannot meet the burden-sharing demand on the military front but we should in the area of environmental preservation."150 One government official's analysis of Takeshita's "Save the Earth" interest was that it stemmed from a belief that Japan must take the initiative in a sphere that lacks a clear leader, and where Japan can use its new wealth and technological prowess to aid the global quality of life. ${ }^{151}$

In addition to the government's positive attitude towards global environment problems, Japanese corporations have been making efforts towards further technological development. They have expressed views favoring government controls on the environment which can prevent the problem of free-ride. ${ }^{152}$

Although Japan's foreign policy and its foreign-policy behavior have been active regarding the preservation of the environment since 1989, there are global disagreements which might curb Japan's efforts. There is widespread skepticism in Japan and abroad about whether the initiative is more style

150 Cited by Katsuro Kitamatsu in "'Save the Earth' initiative launched," The Japan Economic Journal, Vol.XXVII, No.1361, April 29, 1989: 1 .

151 Ibid.

152 "A Panel Discussion of Environmental Issues and Japanese Policy," Japan 21st, Vol.XXXVIII, No.6, June 1993: 63-68. 
than substance because many critics feel took Japan too long to show its interest in taking up its environmental responsibilities. Some developing countries believe that economic development is their first priority, rather than preservation of the environment. Even among industrial countries, there are disagreements about approaches to the issues. On one hand, France, the Netherlands, and Norway are urging that industrial nations uniformly cut domestic emissions of carbon dioxide and introduce punitive measures to achieve that goal. On the other hand, the United States and Japan have countered that simple regulations would be counterproductive to industrial activities.

Moreover, Japan is often criticized for its extensive use of tropical timber and its attitudes toward resource conservation. Japan heavily depends on natural resources imported from foreign countries. Any solution would require changes in Japanese lifestyle.

There is a world-wide trend not to sacrifice economic development for environmental protection, despite the United nations' adoption of a "sustainable development" model. Yet most nations want to reduce the undesirable (and costly) environmental consequences of economic development. Japan is a leader in environmental and/or energy-saving technology which can be used to help countries who are seriously suffering from both security and economic threats caused by 
deforestation, desetification, and acid rain. ${ }^{153}$ Japan experienced environmental disasters in the 1960s caused by rapid industrial growth. Since then Japan has continued environmental efforts on industrial pollution control and it has established a remarkable record in combining substantial improvements in its domestic environment with unprecedented levels of economic growth. ${ }^{154}$ The economic development achieved by some Asian countries during the 1980 s left a similar record as that of Japan in the 1960s. Japanese expertise in industrial pollution control is of use to its neighbors efforts of environmental protection in the region.

since environmental measures require extra cost, the governments of some rapidly industrializing countries in Asia give lower priority to environmental protection. The best available technologies of the advanced industrialized world are not economically feasible for most developing countries. In this respect, Japan could provide the appropriate technologies and use foreign aid policy to influence these governments to regulate environmental policy at home.

In sum, Japan's technological advantage, along with its financial clout, might make it possible to establish sustainable development. There has been a tremendous amount

153 Taizo Yakushiji, "Technology and the setting for Japan's Agenda," Japan's International Agenda, ed. Youichi Funabashi (New York: New York University Press, 1994) 78-79.

154 Hidefumi Imura, "Japan's Environmental Balancing Act," Asian Survey, Vol.XXXIV, No.4, April 1994: 359. 
of willingness and effort devoted to the problem by the Japanese government that cannot be ignored. Given Japanese economic power and technological sophistication, Japan can be a leading nation on the environmental front.

However, for global environmental problems such as climate changes, collective and cooperative actions by governments and industries are indispensable. Whether Japan can succeed of this depends on global consensus and Japanese leadership. 


\section{CHAPTER V}

CONCLUSION: THEORY OF JAPAN'S FOREIGN-POLICY BEHAVIOR

This study has explored factors that influence Japan's foreign-policy behavior issue by issue. The gap between official foreign policy guidelines and its foreign-policy behavior stems from either an overly idealistic policy or lack of independent policy, such as those issues related to Japan's security ties with the United States, economic relations with the Middle East, and historical relationships with other Asian countries. In this concluding chapter, I clarify the findings with a theoretical consideration.

\section{POWER AND INFLUENCE}

Influence is the ability to affect the behavior of others; it is the most relational aspect of power. Influence involves actually changing others' implementation of foreign policy, including making them switch voting positions in the United Nations. Influence may involve encouraging others to continue current behavior. As instruments of influence, states may use diplomatic, military, economic, and psychological methods.

The tools of influence very much depend on a state's capabilities and how those capabilities stand in relation to 
the capabilities of others. During the cold war, power was measured by military capability. As the superpowers declined, many political scientists redefined power. For example, Joseph S. Nye, Jr. emphasized "soft power," and notes:

Traditionally the test of a great power was its strength in war. Today, however, the definition of power is losing its emphasis on military force and conquest that marked earlier eras. The factors of technology, education, and economic growth are becoming more significant in international power, while geography, population and raw materials are becoming somewhat less important.

Hanns W. Maull introduced the concept of "civilian power," which is a non-military, primarily economic, means to secure national goals, with military power left as a residual instrument serving essentially to safeguard other means of international interaction. ${ }^{156}$ Thus we have seen the multidimensionality of power.

\section{Influence Based on Military Power}

The multi-dimensionality of power, however, does not depreciate military power. It implies that military capability itself still represents an aspect of power but that other capabilities, such as the economy, and technology, are becoming increasingly important. The Gulf Crisis proved the continuing relevance of military power, as well as the

155 Joseph S. Nye, Jr., "Soft Power," Foreign Policy, No.80, Fall 1990: 154.

156 Hanns W. Maull, "Germany and Japan: The New Civilian Powers," Foreign Affairs, Vol.69, No.5, Winter 1990/91: 92. 
necessity of economic resources to resolve international crises. As long as international conflicts continue, military power seems unlikely to be replaced by soft power alone. The military dimension is still a central aspect of the capabilities of states.

Throughout history, military capabilities have been the most influential factor determining a state's behavior. Although the use of military capabilities is generally a coercive or punishment-oriented means of influence, they could be used to influence others by rewarding others. Russett and starr note two way to influence states by rewarding them with military capabilities. States may attempt to influence commitment to an alliance, U.N. voting, or general political orientation by extending military aid. ${ }^{157}$ or states may influence others by promising to add to their capabilities, which is a main feature of alliances. ${ }^{158}$ The latter is indicative of Japan's situation. Given the Peace Constitution and the security treaty with the United States, Japan has maintained its pacifist positions, and has relied on the United States on security matters. Therefore, the United States has exerted a crucial influence upon Japan's foreign-policy behavior, including U.N. voting.

As revealed in the previous chapter, this influence, based on the military power of the United states, was

157 Russett and starr, 166.

158 Ibid. 
significant on issues of arms control and disarmament, and economic development in developing countries. To a lesser degree, Japan was also influenced by the United States on Middle East issues and human rights issues.

\section{Influence Based on Economic Resources}

States rely on each other for resources and commodities that enable them to develop and sustain their economies and the well-being of their peoples. ${ }^{159}$ This reliance is central to the ideas of leverage and vulnerability. Economic resources can be manipulated by those who possess them to influence those who do not. Economic resources can be used to the same ends as military capability. Negatively, states may take away, threaten to cut off, or fail to provide another with some economic resource, commodity, or service.

The Arab states have used their oil resources to affect the West. They control such a large portion of the oil supply that finding alternative sources of petroleum is difficult. Japan, because of its lack of energy resources, has relied on supplies from other countries. Especially, its oil reliance on the Arab states has made Japan vulnerable to economic threats. After the oil crisis of 1973, even though Japan has devoted itself to developing the technology for energy efficient products, and diversifying its sources of oil and other energy supplies, the Arab states are still crucial to

159 Ibid., 175 . 
Japan. Its economy remains very vulnerable.

Japan, as well as European countries, has been influenced by the Arab states. The Arab states do not exert the same influence upon the United states because of its petroleum reserves; but these reserves are not sufficient to supply the needs of the other Western countries. This reality is reflected in the voting maps. Japan and the European countries always took a pro-Arab stance on the IsraeliPalestinian conflict and Palestinian refugee problem, while the United States kept a pro-Israel position.

similarly, Japan depends heavily on imported natural resources from Asian countries. However, the influence exerted by Asian states through their supplies of natural resources cannot compare with that of the Arab states, since Japan also uses foreign investment, technological transfer, and economic aid to counterbalance Asian states' resources. This economic interdependence makes Japan less vulnerable.

\section{Influence Based on Psychological Constraints}

In another way, states may use psychological techniques to exercise influence.

Japan's historical experience with other Asian countries is the source of yet another of Japan's vulnerabilities. The historical legacy of Japanese expansionism in the pre-war era is one of Japanese exploitation of the wealth and resources of its neighbors in order to expand Japan's growing empire. Japan dealt most cruelly with the peoples of Asia. These 
experiences have created a lasting bitterness among Asians toward Japan. Moreover, the Japanese themselves were to experience a moral and psychological trauma arising from their own past. Popular emotion among Asians against Japan still functions as an important determinant in regional relations. ${ }^{160}$ whenever difficult issues arise in bilateral relations, such as the trade imbalance, questions of new guidelines for aid, and violation of human rights, the emotional legacy looms up to strain negotiations.

This historical constraint can be observed in Japan's voting behavior on human rights issues. Japan's frequent abstention from sensitive human rights issues is nothing but a manifestation of the lasting influence of the wartime legacy upon relations between Japan and other Asian countries. And as noted before, it also affects Japan's implementation of the new guidelines for foreign aid.

\section{A IACK OF COHERENT FOREIGN POLICY}

It is obvious that before it can implement a foreign policy, a government needs to have one. Foreign policy has a crucial role to perform in the international affairs. It is necessary for governments to organize general structures which make their international activities at least compatible

160 Masahide Shibusawa, Zakaria Haji Ahmad, and Brian Bridges, Pacific Asia in the 1990s (New York: Routledge, 1992) 137 . 
with their core interests. ${ }^{161}$ simply, ambiguous government policies do not help states to take any international actions.

Japan has held an idealistic set of guidelines on many international issues and its application of foreign policy is inconsistent. The inconsistency stems from Japan's belief that each nation-state has different values, cultures, and traditions, therefore it is not appropriate to deal with nation-states in a single-minded fashion. This respect for cultural relativity could be seen in Japan's attitude toward human rights issues, the Middle East peace problem, and environmental issues, to some extent. Similarly, Japan's ambivalent stance of advocating cooperation with everybody makes it difficult to take a coherent policy.

Given its too general official guidelines and its priority of cooperation with everybody, Japan uses the international framework and diplomacy to determine its behavior toward international issues. Diplomacy is the preferred political technique, because it involves direct government to government interactions. Today much activity occurs in multilateral forums. Especially, since Japan has not been involved in any international political framework except the G-7, Japan has used the summits to coordinate its foreign policy. Thus voting maps shows Japan's high

161 Steve Smith and Michael clarke, Foreign Policy Implementation (London: George Allen \& Unwin, 1985) 179. 
concurrence with G-7 members.

\section{A FINAL WORD}

In changing international environment and because of its economic power, Japan has been expected to exercise a more active diplomacy. However, currently Japan's performance remains much as it has been. Its foreign policy remains ambiguous and idealistic. Its foreign-policy behavior does not reflect its policy. Without a coherent and concrete foreign policy, Japan ends up displaying ambivalent behavior, and covers up its inaction with foreign aid. This study demonstrates that on selective international issues the discrepancy between its foreign policy and foreign-policy behavior stems largely from external military, economic, and cultural influence. Japan's foreign-policy behavior on arms control and disarmament issue is mostly influenced by the military power of the United States. On economic development in developing countries it is influenced by the economic resources of developing nations, and particularly in Asia by historical constraints. Japan's behavior on human rights issue is constrained by the socio-cultural and political factors related to its cloudy relations with its neighbors. on the Middle East peace problem, its behavior is affected by the economic resources of the region, and relations with the United States. Further, Japan's lack of coherent and concrete foreign policy creates delayed reactions to international 
crises, inconsistency in implementing foreign policy, and dependency on the United States or other G-7 members. Only on global environmental issues, where there are no significant influential factors to constrain Japan's foreign-policy behavior, given its technological and financial capability, it is possible to be a leading state as the Government of Japan wishes. 


\section{SELECTED BIBLIOGRAPHY}

Akaha, Tsuneo, and Langdon, Frank, eds. Japan in the Posthegemonic World. Boulder: Rienner, 1993.

Alker, Hayward R., and Bruce M. Russett. World Politics in the General Assembly. New Haven: Yale University Press, 1967.

Arase, David. "Japanese Policy Toward Democracy and Human Rights in Asia." Asian Survey 33.10 (1993): 935-952.

Asai, Nobuo. "Walking a Tightrope in the Middle East." Japan Quarterly 39.4 (1991): 407-415.

Binyan, Liu. "The Beijing-Tokyo Axis Against Human Rights." New Perspectives Quarterly 9.1 (1992): 31-33.

Brown, Eugene. "The Debate Over Japan's Strategic Future." Asian Survey 43.6 (1993): 543-559.

Curtis, Gerald L., ed. Japan's Foreign Policy After the cold War. New York: M.E. Sharpe, Inc., 1993.

Drifte, Reinhard. Japan's Rise to International Responsibilities. Atlantic Highlands: The Athlone Press, 1990 .

Elek, Andrew. "APEC - Motives, Objective and Prospects." Australian Journal of International Affairs 46.2 (1992): 161-173.

Funabashi, Youichi, ed. Japan's International Agenda. New York: New York University Press, 1994.

Hayao, Kenji. The Japanese Prime Minister and Public Policy. Pittsburgh: University of Pittsburgh Press, 1993.

Holloway, Steven. "Forty Years of United Nations General Assembly Voting." Canadian Journal of Politics Science $23.2(1990): 279-296$.

Howell, Llewellyn D. "A Comparative Study of the WEIS and COPDAB Data Sets." International Studies Quarterly 27 (1983): 149-168. 
Imura, Hidefumi. "Japan's Environmental Balancing Act." Asian Survey 34.4 (1994): 355-368.

Inoguchi, Kuniko. "The Changing significance of the G-7 Summits." Japan Review of International Affairs 8.1 (1994): 21-38.

Inoguchi, Takashi. Japan's International Relations. Boulder: Westview Press, 1991.

--- Japan's Foreign Policy in an Era of Global Change. New York: St. Martin's Press, 1993.

Itagaki, Yuzo. Nihonjin yo Kakugo wa Dekiteiruka (Are You Japanese Ready?). Tokyo: KK Bestsellers, 1991.

Itoh, Hiroshi, ed. Japanese Politics. Itheca: cornell University Press, 1973.

Japan. Ministry of foreign Affairs. Diplomatic Bluebook 1988 . Tokyo: The Japanese Foreign Ministry, 1988.

--. --. Diplomatic Bluebook 1989. Tokyo: The Japanese Foreign Ministry, 1989.

--. -.-. Diplomatic Bluebook 1990. Tokyo: The Japanese Foreign Ministry, 1990.

--. --.. Diplomatic Bluebook 1991. Tokyo: The Japanese Foreign Ministry, 1991.

--. ---. Diplomatic Bluebook 1992. Tokyo: The Japanese Foreign Ministry, 1992 .

Japan Echo. The Japan of Today. Tokyo: The International Society for Educational Information Inc., 1993.

The Japanese Association of International Law. Japan and the United Nations. New York: Manhattan Publishing Company, 1958 .

Johnson, Janet Buttolph, and Richard A. Joslyn. Political Science Research Methods. 2nd ed. Washington, D.C.: Congressional Quarterly Inc., 1991.

Kaplan, Morton A., and Kinhide Mushakoji, eds. Japan, America, and the Future World order. New York: The Free Press, 1976.

Katz, Joshua D, and Tilly C. Friedman-Lichtshein, eds. Japan's New World Role. Boulder: Westview Press, 1985. 
Kitamatsu, Katsuro. "Save the Earth' initiative Launched." The Japan Economic Journal 29 April 1989: 1.

Lerche, Charles 0 , Jr. and Said, Abdul A. Concept of International Politics. New Jersey: Prentice-Hall, Inc., 1970.

Lincoln, Edward J. Japan's New Global Role. Washington D.C.: The Brooking Institution, 1993.

MacClelland, Charles A. "Let the User Beware." International Studies Quarterly 27 (1983): 169-177.

Makin, John H., and Donald C. Hellmann, eds. Sharing World Leadership? Washington, D.C.: American Enterprise Institute for Public Policy Research, 1989.

Marin-Bosch, Miguel. "How Nations Vote in the General Assembly of the United Nations." International organization 41.4 (1987): 705-724.

Matsushita, Kazuo. "Japan Offers Negative-Positive Ecological Model." Japan Economic Journal 16 July 1988: 23.

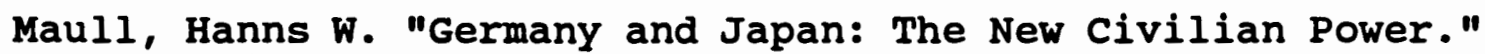
Foreign Affairs 69.5 (1990-91): 91-106.

Morgenthau, Hans J. Politics Among Nations. 5th ed. New York: Alfred A. Knopf, INC., 1973.

Morrison, Charles E. "The United States and cooperation in the Asia-Pacific." Australian Journal of International Affairs 48.1 (1994): 63-73.

Nagami, Yoshiji. "Japan's Middle East Policy in Transition." Japan Review of International Affairs 7.2 (1993): 103113.

Nakajima, Ai. "Tokyo seeking bigger say in global nuclear controls." The Nikkei Weekly 22 Mar 1992: 2 .

Nakanishi, Terumasa. "The United Nations and Japan's Place in It." Japan Echo 19 Special Issue (1992): 66-72.

Naramoto, Eisuke. "Japan Aligned with the PLO." Japan Quarterly 37.1 (1990): 19-23.

Noressis, Marija J. SPSS-X Introductory statistics Guide. Chicago: SPSS Inc., 1988. 
Nye, Joseph S, Jr. "Soft Power." Foreign Policy 80 (1990): 153-171.

Ogata, Sadako. "The United Nations and Japanese Diplomacy." Japan Review of International Affairs 9.2 (1990): 141165.

Peek, John M. "Japan, the United Nations, and Human Rights." Asian Survey 32.3 (1992): 217-229.

Peterson, M.J. The General Assembly in World Politics. Boston: Allen \& Uniwin Inc., 1986.

Pyle, Kenneth B. The Japanese Question: Power and Purpose in a New Era. Washington, D.C.: The AEI Press, 1992.

Riggs, Robert E., and Jack C. Plano. The United Nations. Belmont: Wadsworth Publishing Company, 1994.

Rosario, Louise do. "Reluctant Convert: Tokyo Begins to Speak up on Human Rights." Far Eastern Economic Review 22 Aug 1991: 14-15.

Rosenau, James N. Comparing Foreign Policy. New York: Halsted Press, Division of John Wiley \& Sons, Inc., 1974.

Russett, Bruce, and Harvey starr. World Politics. New York: W.H. Freeman and Company, 1989.

Saito, Shiro. Japan at the Summit: Japan's Role in the Western Alliance and Asian Pacific Co-operation. New York: Routledge, 1990.

Saito, Shizuo. "The United Nations and the Issues of a Fluid Global Society." Japan Review of International Affairs 7.3 (1993): 234-253.

Scalapino, Robert A., ed. The Foreign Policy of Modern Japan. Berkeley: University of California Press, 1977.

Shibusawa, Masahide. Japan and the Asian Pacific Region. New York: Routledge, 1989.

Shibusawa, Masahide, Zakaria Haji Ahmad, and Brian Bridges. Pacific Asia in the 1990s. New York: Routledge, 1992.

Smith, Steve, and Michael clarke. Foreign Policy Implementation. London: George Allen \& Unwin, 1985. 
Soeya, Yoshihide. "The Evolution of Japanese Thinking and Policies on Cooperative Security in the $1980 \mathrm{~s}$ and 1990s." Australian Journal of International Affairs 48.1 (1994): 87-95.

Sugihara, Kaoru, and J.A. Allan, eds. Japan in the Contemporary Middle East. New York: Routledge, 1993.

Takagi, Hisao. "Similar ends, different means." The Nikkei Weekly 7 Dec 1991: 2.

---. "Japan pursues own diplomacy on international human rights." The Nikkei Weekly 1 Aug 1992: 1-2.

Takeda, Isami. "A New Dialogue for Japan, ASEAN, and Oceania." Japan Echo 20, Special Issue (1993): 72-76.

Takeda, Tatsuo. Nihon no Gaikou: Sekkyoku Gaikou no Jouken (Japan's Foreign Policy: Toward Active Diplomacy). Tokyo: The Simul Press, 1990.

Unger, Danny, and Paul Blackburn, eds. Japan's Emerging Global Role. Boulder: Rienner, 1993.

United Nations. General Assembly. Department of Public Information. Press Release GA/7814. "Resolutions and Decisions Adopted by the General Assembly during its Forty-Third Session. From 20 September to 22 December $1988 . "$

---. --.. ---. Press Release GA/8307. "Resolutions and Decisions Adopted by the General Assembly during its Forty-Sixth Session. From 17 September to 20 December 1991."

United States. Department of State. Bureau of International organization Affairs. United states Participation in the United Nations 1991. Washington, D.C.: The U.S. Government Printing Office, 1992 .

Valeo, Francis R., and Charles E. Morrison, eds. The Japanese Diet and the U.S. Congress. Boulder: Westview Press, 1983 .

Waltz, Kenneth N. Theory of International Politics. New York: McGraw-Hill, Inc., 1979.

Wilkenfeld, Jonathan, et al. Foreign Policy Behavior: The Interstate Behavior Analysis Model. Beverly Hills: Sage Publications, 1980. 
Yamamoto, Yoshinobu. "The Role of the G-7 summit in the New International system." Japan Review of International Affairs 12.3 (1993): 161-176.

---. "Japan's Security Policies in the Post-Cold War Era." Australian Journal of International Affairs 47.2 (1993): 286-299.

Yasutomo, Dennis T. "Why Aid? Japan as an 'Aid Great Power'." Pacific Affairs $62.4(1989-90): 490-503$.

"A Panel Discussion of Environmental Issues and Japanese Policy." Japan 21st 38.6 (1993): 63-68.

"A turning point in UN history: toward a search for common ground." UN CHRONICLE 22.1 (1990): 4-11.

"Assembly agrees on major human rights, developing issues," UN CHRONICLE 28.1 (1991): 4-11.

"Reform Proposals Circulate During 46th Assembly." UN CHRONICLE 29.1 (1992): 9-11.

"Tokyo commits to 5-year aid package for environmental protection." The Nikkei Weekly 20 June 1992: 2 .

"UN-Representative Japan." LOOK JAPAN 39.451 (1993): 4-9. 
APPENDIX A

FACTOR SCORES BY COUNTRY OF THE 43RD GENERAL ASSEMBLY

COUNTRIES

Afghanistan

Albania

Algeria

Angola

Antigua \& Barbuda

Argentina

Australia

Austria

Bahamas

Bahrain

Bangladesh

Barbados

Belgium

Belize

Benin

Bhutan

Bolivia

Botswana

Brazil

Brunei Darussalam

Bulgaria

Burkina Faso

Burundi

Byelorussian SSR

Cambodia

Cameroon

Canada

Cape Verde

Central Africa Rep.

Chad

Chili

China

Colombia

comoros

Congo

Costa Rica

Ivory coast

Cuba

Cyprus

Czechoslovakia
FACTOR

$\begin{array}{rr}.301 & -.093 \\ 2.250 & .062 \\ .376 & .093 \\ .259 & -.087 \\ .372 & -.076 \\ .376 & .095 \\ -2.477 & .193 \\ -2.872 & .042 \\ .453 & -.135 \\ .408 & .025 \\ .408 & -.063 \\ .403 & -.144 \\ -2.080 & .550 \\ .938 & -.363 \\ .272 & -.065 \\ .196 & -.074 \\ .356 & -.015 \\ .452 & .068 \\ .281 & .246 \\ .562 & -.045 \\ .354 & -.117 \\ .360 & -.065 \\ .372 & -.005 \\ .380 & -.087 \\ 1.198 & -.189 \\ .520 & -.323 \\ -2.133 & .630 \\ .263 & -.064 \\ .306 & .014 \\ .408 & .025 \\ -.087 & -.122 \\ .464 & .012 \\ .196 & .029 \\ .450 & .006 \\ .196 & 3.221 \\ .590 & .252 \\ .227 & -.395 \\ .434 & .150 \\ .195 & -.080 \\ .380 & -.089\end{array}$

FACTOR 3

$$
\begin{array}{r}
.119 \\
-.492 \\
.373 \\
.492 \\
.035
\end{array}
$$$$
.043
$$

1.265

2.503

$-.031$

.292

.143

.190

$-3.206$

$-.742$

$-.232$

$-.010$

$-.214$

.039

.581

.133

$-.207$

.005

.022

$-.194$

.066

$-.445$

$-.526$

.028

.156

$-.208$

$-.729$

$-.117$

$-.310$

$-.362$

$-.709$

$-.193$

.516

.391

.440

$-.194$
FACTOR 4

$-.046$

$-.938$

$-.118$

.324

$-.134$

.129

$-.321$

$-.047$

2.459

$-.052$

.285

$-.106$

.532

2.241

$-.083$

$-.166$

$-.264$

$-.123$

$-.367$

$-.095$

$-.055$

$-.111$

$-.129$

$-.123$

$-.703$

$-.567$

$-.051$

.183

$-.054$

$-.078$

$-.478$

.379

$-.326$

.472

$-1.030$

.078

.111

$-.079$

.286

$-.123$ 


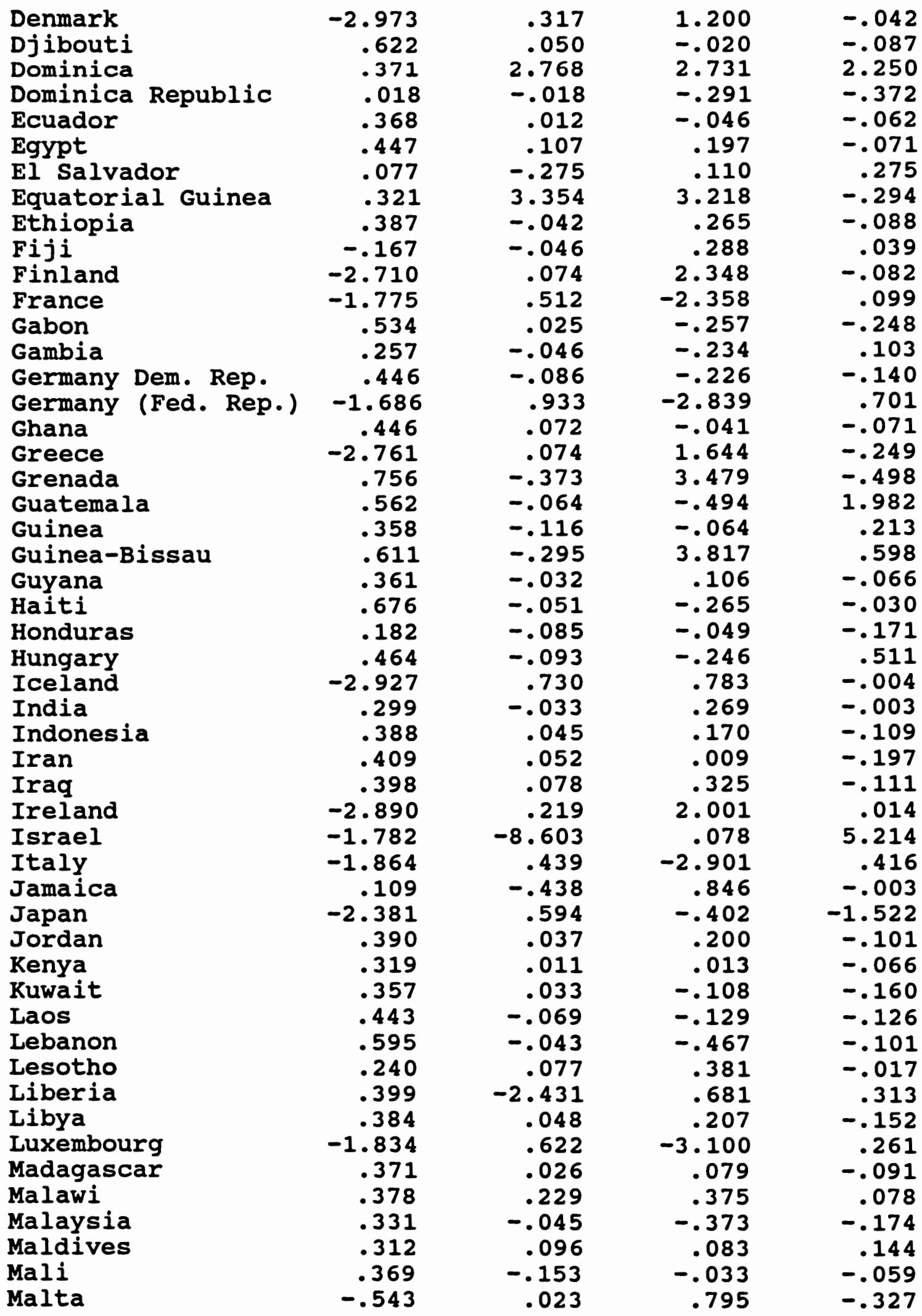




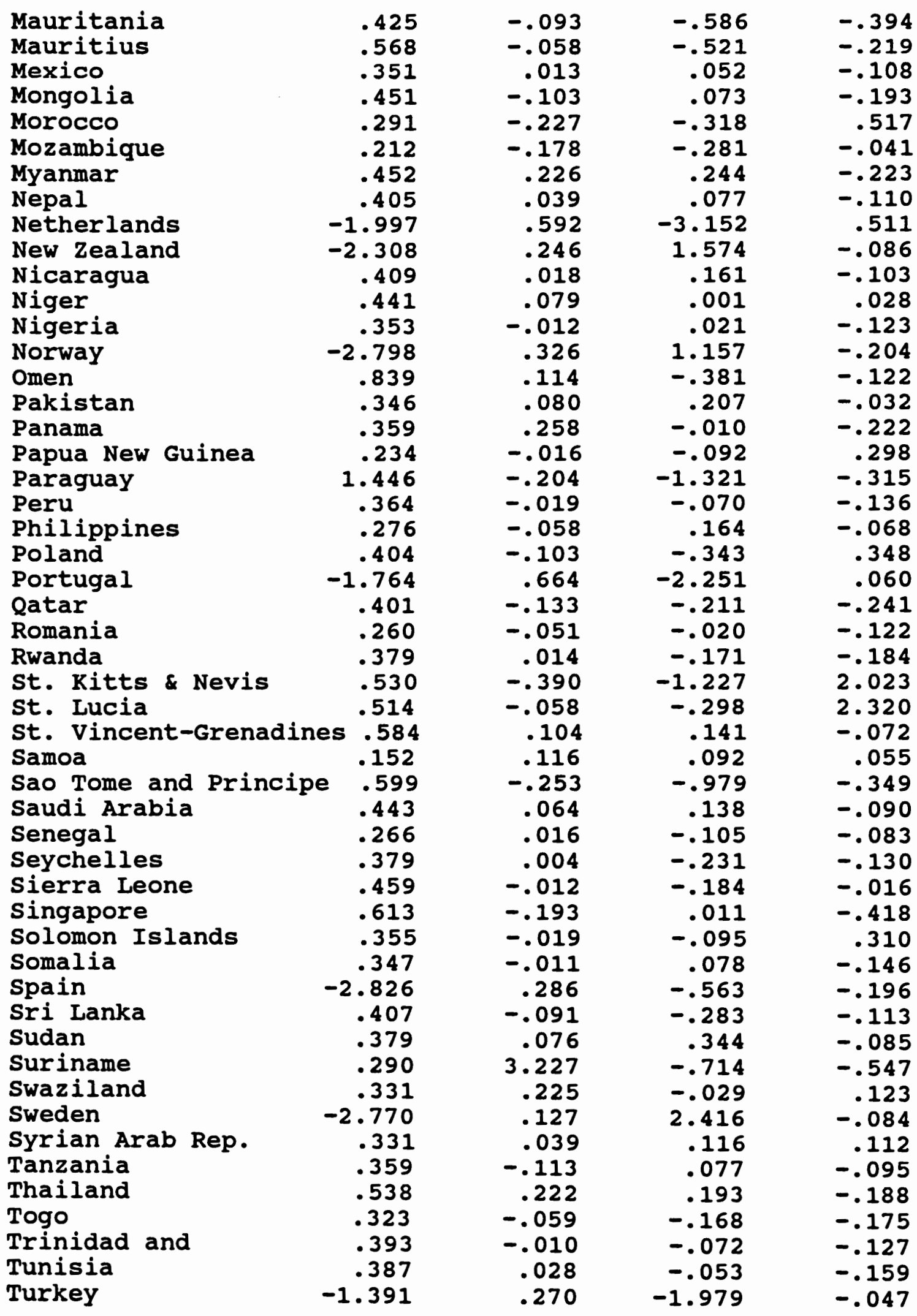




$\begin{array}{lrrrr}\text { Uganda } & .439 & .230 & -.005 & -.051 \\ \text { Ukrainian SSR } & .380 & -.087 & -.194 & -.123 \\ \text { United Arab Emirates } & .380 & -.087 & -.194 & -.123 \\ \text { United Kingdom } & -1.516 & 1.144 & -1.318 & 1.741 \\ \text { United States } & -.920 & -4.940 & -.784 & -9.216 \\ \text { USSR } & .419 & -.032 & -.225 & -.127 \\ \text { Uruguay } & .167 & .003 & -.122 & -.026 \\ \text { Vanuatu } & .458 & -.404 & -.124 & .412 \\ \text { Venezuela } & .208 & .067 & .149 & -.006 \\ \text { Viet Nam } & .362 & -.009 & .153 & -.132 \\ \text { Yemen } & .485 & .146 & -.494 & -.306 \\ \text { Yemen PDR } & .225 & -.125 & .071 & -.060 \\ \text { Yugoslavia } & .337 & .034 & .165 & -.103 \\ \text { Zaire } & .239 & -2.130 & 1.310 & .097 \\ \text { Zambia } & .267 & -.034 & .371 & .025 \\ \text { Zimbabwe } & .463 & -.022 & .151 & .111\end{array}$


APPENDIX B

FACTOR SCORES BY COUNTRY OF THE 46TH GENERAL ASSEMBLY

COUNTRIES

Afghanistan

Albania

Algeria

Angola

Antigua-Barbuda

Argentina

Australia

Austria

Bahamas

Bahrain

Bangladesh

Barbados

Belarus

Belgium

Belize

Benin

Bhutan

Bolivia

Botswana

Brazil

Brunei Darussalam

Bulgaria

Burkina Faso

Burundi

Cambodia

Cameroon

Canada

Cape Verde

Central Africa Rep.

Chad

Chile

China

Colombia

Comoros

Congo

Costa Rica

Ivory coast

Cuba

Cyprus

Czechoslovakia
FACTOR 1 FACTOR 2

.458

$-1.599$

.411

.629

$-.140$

$-1.615$

$-1.575$

$-1.718$

.579

.559

.723

.427

$-1.253$

$-1.606$

.525

.408

.354

.431

.589

.470

.571

$-1.648$

.466

.460

.930

.624

$-2.032$

.754

1.373

.557

.514

.995

.425

.548

.732

.545

.215

.576

.157

$-2.231$

\section{AATOR 2}

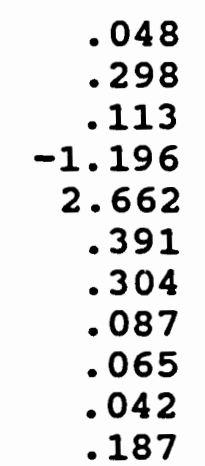

$-.025$

$-1.489$

.649

$-.458$

$-.008$

.275

$-.087$

.026

.103

.133

.485

$-.772$

$-.134$

2.674

$-.242$

$-.405$

$-.156$

.003

.042

.275

.188

$-.010$

$-.306$

$-.686$

$-.203$

$-.394$

.131

$-.163$

.243
FACTOR 3

$-.328$

$-.310$

$-.314$

3.433

2.276

$-.206$

$-.284$

$-.052$

$-.088$

$-.266$

$-.394$

$-.278$

3.727

$-.121$

$-.445$

.225

$-.455$

$-.137$

$-.248$

$-.282$

$-.300$

$-.138$

3.124

.094

1.188

$-.162$

.043

$-.403$

$-.288$

$-.266$

$-.356$

$-.022$

.224

$-.878$

.723

.090

$-2.303$

$-.136$

.209

.089
FACTOR 4

$-.384$

.375

$-.296$

1.767

$-.475$

$-.217$

.322

.489

.014

$-.114$

$-.038$

.029

$-.151$

.094

1.282

$-.145$

$-1.404$

$-.036$

$-.029$

$-.298$

.116

.533

$-.173$

$-.083$

2.749

$-.058$

.586

$-.087$

$-.105$

$-.114$

$-.192$

$-1.753$

$-.021$

2.110

$-.383$

.046

.668

$-1.371$

$-.471$

.579 
Denmark

Djibouti

Dominica

Dominican Republic

Ecuador

Egypt

El Salvador

Equatorial Guinea

Estonia

Ethiopia

Fiji

Finland

France

Gabon

Gambia

Germany

Ghana

Greece

Grenada

Guatemala

Guinea

Guinea-Bissau

Guyana

Haiti

Honduras

Hungary

Iceland

India

Indonesia

Iran

Irag

Ireland

Israel

Italy

Jamaica

Japan

Jordan

Kenya

Korea DPR

Korea Rep.

Kuwait

Laos

Latvia

Lebanon

Lesotho

Liberia

Libya

Liechtenstein

Lithuania

Luxembourg

Madagascar

\begin{tabular}{|c|c|}
\hline 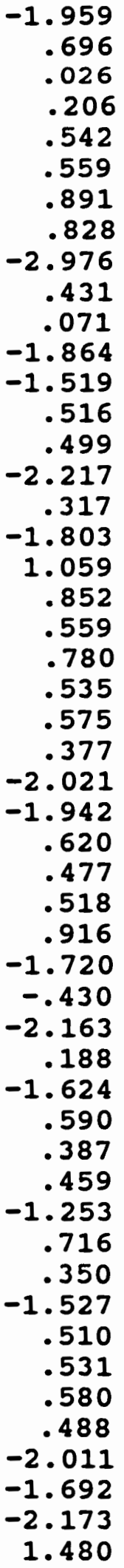 & $\begin{array}{r}.471 \\
-.525 \\
-.092 \\
-.016 \\
-.249 \\
.042 \\
-.000 \\
.023 \\
-.038 \\
-.002 \\
.430 \\
.327 \\
.061 \\
.153 \\
.010 \\
.132 \\
.209 \\
-3.926 \\
.350 \\
-.022 \\
.292 \\
.013 \\
-.017 \\
-.0338 \\
-.134 \\
.098 \\
.129 \\
-.508 \\
-.076 \\
.072 \\
.551 \\
-.068 \\
.157 \\
.413 \\
.363 \\
.228\end{array}$ \\
\hline
\end{tabular}

$-.095$

$-.455$

5.240

2.110

$-.414$

$-.266$

2.520

$-.449$

$-1.176$

$-.324$

$-.230$

$-.435$

.451

$-.397$

$-.385$

$-.100$

3.243

.311

2.560

$-.677$

$-.266$

.063

$-.252$

$-.232$

$-.153$

$-.163$

$-.085$

.405

$-.297$

$-.242$

$-.078$

$-.094$

$-4.711$

$-.157$

$-.038$

.206

$-.354$

1.061

$-.391$

.191

$-.324$

$-.156$

$-.416$

$-.107$

$-.216$

.052

$-.210$

$-.129$

$-.070$

$-.153$

$-.650$
.205

$-.204$

$-.200$

$-1.147$

$-.094$

$-.114$

$-1.157$

$-.269$

.170

$-.228$

$-.072$

.616

$-2.160$

$-.119$

$-.318$

.463

$-.479$

.190

3.251

3.630

$-.114$

$-.667$

$-.045$

.944

$-.008$

.850

$-.010$

$-2.353$

$-.245$

.004

.445

.468

1.724

.530

.164

.199

$-.215$

$-.569$

$-.019$

$-.399$

$-.224$

$-1.046$

$-.325$

.021

.108

$-.300$

$-.005$ .208

$-.056$

.541

$-.689$ 
Malawi

Malaysia

Maldives

Mali

Malta

Marshal Islands

Mauritania

Mauritius

Mexico

Micronesia

Mongolia

Morocco

Mozambique

Namibia

Nepal

Netherlands

New Zealand

Nicaragua

Niger

Nigeria

Norway

Omen

Pakistan

Panama

Papua New Guinea

Paraguay

Peru

Philippines

Poland

Portugal

Qatar

Romania

Rwanda

st. Kitts \& Nevis

st. Lucia

St. Vincent-Grenadines .150

Samoa

Sao Tome and principe

Saudi Arabia

Senegal

Seychelles

Sierra Leone

Singapore

Solomon Islands

Somalia

South Africa

Spain

Sri Lanka

Sudan

Suriname

Swaziland

$\begin{array}{rr}.670 & .836 \\ .518 & .010 \\ .533 & .013 \\ .193 & -.156 \\ -.897 & -.108 \\ -.536 & .009 \\ . .404 & -.086 \\ -.080 & .004 \\ .534 & .021 \\ .595 & -.118 \\ .730 & .110 \\ .458 & .276 \\ .686 & .060 \\ .518 & .000\end{array}$

.614

$-1.666$

$-1.401$

.545

.626

.535

$-2.040$

.559

.518

$-.978$

.729

.040

.640

.691

$-1.956$

$-1.863$

.518

$-1.831$

1.695

.620

.469

$-.012$

.843

.546

.796

1.011

.657

.483

.142

1.138

.535

$-1.930$

.544

.308

.535

.536
$-.290$

$-.242$

$-.244$

$-.475$

.132

$-.745$

$-.305$

$-.588$

$-.251$

$-.048$

$-.519$

$-.398$

$-.361$

$-.229$

$-.342$

$-.113$

$-.312$

$-.186$

$-.370$

$-.252$

$-.089$

$-.266$

$-.242$

3.558

$-.797$

$-.173$

$-.593$

$-.308$

$-.244$

$-.039$

$-.242$

$-.136$

1.391

1.450

$-.117$

$-.307$

$-.112$

$-.428$

$-.274$

$-.184$

$-.846$

$-.865$

$-.193$

$-.510$

.074

$-.252$

.414

$-.268$

$-.485$

$-.252$

$-.024$
.207

.004

$-.007$

.042

.306

$-.625$

.115

$-.232$

$-.050$

$-.530$

$-.022$

$-.145$

$-.000$

$-.199$

$-.048$

.136

.247

$-.012$

$-.166$

$-.045$

$-.021$

$-.114$

.004 .048

$-.205$

$-.179$

$-.190$

$-.160$

.454

.347

.004

.459

2.902

2.972 .034

$-.096$

$-.151$

$-.122$

.108

$-.138$

$-.786$

3.362

$-.043$

$-.034$

$-.224$

$-.045$

.318

.012

$-.192$

$-.045$

$-.018$ 


Sweden
Syria
Tanzania
Thailand
Togo
Trinidad and Tobago
Tunisia
Turkey
Uganda
Ukraine
United Arab Emirates
United Kingdom
United states
UssR
Uruguay
Vanuatu
Venezuela
Viet Nam
Yemen
Yugoslavia
Zaire
Zambia
Zimbabwe

$\begin{array}{rr}-1.996 & .286 \\ .765 & .029 \\ .520 & -.032 \\ .433 & .074 \\ .417 & -.007 \\ .522 & .013 \\ .539 & .067 \\ -1.500 & -.102 \\ .547 & .052 \\ -.210 & -.012 \\ .518 & .010 \\ -1.020 & 1.076 \\ -.119 & -3.928 \\ -.538 & -5.728 \\ .173 & .478 \\ .135 & .165 \\ .542 & .127 \\ .372 & .035 \\ .354 & .087 \\ .470 & .103 \\ .019 & 2.645 \\ .536 & .029 \\ .444 & .054\end{array}$
$-.203$
$-.168$
.109
$-.280$
$-.257$
$-.244$
$-.297$
.136
$-.021$
.114
$-.242$ .605
$-.969$
.119
.429
$-.682$
$-.414$
$-.278$
$-.328$
$-.282$
1.936
$-.018$
$-.417$ .209 .467

$-.156$

$-.123$ .036

$-.007$

$-.199$

$-.598$

$-.344$ .446 .004

$-4.580$

$-5.915$

1.137 .217

$-.153$

$-.094$

$-.230$

$-.381$

$-.298$

$-1.154$

-.111

.671 